University of Tennessee Health Science Center

UTHSC Digital Commons

\title{
Synthesis of Novel Sulfonamide-Based Calpain Inhibitors and Their Potential as Anti-Tumor Agents
}

Jin Xu

University of Tennessee Health Science Center

Follow this and additional works at: https://dc.uthsc.edu/dissertations

Part of the Medicinal and Pharmaceutical Chemistry Commons, and the Pharmaceutics and Drug Design Commons

\section{Recommended Citation}

Xu, Jin , "Synthesis of Novel Sulfonamide-Based Calpain Inhibitors and Their Potential as Anti-Tumor Agents" (2007). Theses and Dissertations (ETD). Paper 297. http://dx.doi.org/10.21007/ etd.cghs.2007.0361.

This Thesis is brought to you for free and open access by the College of Graduate Health Sciences at UTHSC Digital Commons. It has been accepted for inclusion in Theses and Dissertations (ETD) by an authorized administrator of UTHSC Digital Commons. For more information, please contact jwelch30@uthsc.edu. 


\title{
Synthesis of Novel Sulfonamide-Based Calpain Inhibitors and Their Potential as Anti-Tumor Agents
}

\begin{abstract}
Calpain is a class of intracellular cytoplasmic cysteine proteases. 1 The enzyme participates in different intracellular signaling pathways that are mediated by $\mathrm{Ca} 2+.2$ The two major isoforms of calpain universally distributed in most mammalian tissues are calpain 1 ( $\mu$-calpain) and calpain 2 (m-calpain). The exact in vivo function of the enzyme is not clear, but calpain has been implicated in a variety of physiological and pathological conditions, 3 such as cancer, stroke, cardiac ischaemia, muscular dystrophy, cataract and Alzheimer's disease. Calpain inhibitors are therefore of interest as therapeutic agents and as biomedical tools.

Several potent calpain inhibitors isolated from natural sources as well as synthesized in the laboratory have been reported (Chapter 1.4). Unfortunately, most of the inhibitors show poor calpain selectivity, metabolic stability and cell permeability. In an attempt to develop potential calpain inhibitors based on the $\mathrm{X}$-ray crystal structure of the $\mu$-calpain, $\mathrm{NCl}$ compound library was screened by virtual screening method and diazosulfonamide $1(K \mathrm{i}=1.0 \pm 0.02 \mu \mathrm{M})$ was identified as a new nonpeptide competitive inhibitor of $\mu$-calpain. Analogues of 1 were synthesized to explore structure requirements of 1 (Chapter 2 ). In order to test the hypothesis that derivatives of diazosulfonamide 1 with an electrophilic group can have a covalent interaction with cysteine at the active site of calpain, novel sulfonamide-based peptidomimetic analogues of 1 were synthesized and assayed for their ability to inhibit $\mu$-calpain utilizing a kinetic fluorescence assay and for their anti-tumor ability by SRB colorimetric assay (Chapter 3 ). Introduction of the electrophilic functionality significantly enhanced calpain inhibition. From 13 target compounds, 7 compounds had better calpain 1 inhibition ( $K \mathrm{i}$ ranging from 9 to $500 \mathrm{nM}$ ) than 1 and 5 showed good anticancer activity (GI50 ranging from 4 to $22 \mu \mathrm{M}$ ). Sulfonamide-based peptidomimetic analogue 19 with $K \mathrm{l}$ of $9 \mathrm{nM}$ is over 100 -fold more potent than the lead diazosulfonamide 1 . Compound 16 was the most effective anticancer agent ( $\mathrm{GI} 504 \mu \mathrm{M})$ of the series.
\end{abstract}

\section{Document Type}

Thesis

Degree Name

Master of Science (MS)

Program

Pharmaceutical Sciences

Research Advisor

Isaac O. Donkor, Ph.D.

\section{Keywords}

calpain, anti-cancer, calpain inhibitors, sulfonamide analogs

\section{Subject Categories}

Medicinal and Pharmaceutical Chemistry | Medicine and Health Sciences | Pharmaceutics and Drug Design | Pharmacy and Pharmaceutical Sciences 


\title{
SYNTHESIS OF NOVEL SULFONAMIDE-BASED CALPAIN INHIBITORS AND THEIR POTENTIAL AS ANTI-TUMOR AGENTS
}

\author{
A Thesis \\ Presented for \\ The Graduate Studies Council \\ The University of Tennessee \\ Health Science Center
}

In Partial Fulfillment

Of the Requirements for the Degree

Master of Science

From The University of Tennessee

By

Jin $\mathrm{Xu}$

December 2007 
Copyright (C) 2007 by Jin Xu

All rights reserved 


\section{DEDICATION}

This thesis is dedicated to

all my family members and friends

who supported me with their encouragement and help. 


\section{ACKNOWLEDGMENTS}

I would like to thank my advisor, Dr. Isaac O. Donkor, for his help, suggestions, guidance and encouragement throughout my study, research and writing of this thesis. Without his support, it would have been impossible to accomplish any of them. I would like to express my thanks to my other committee members, Dr. Wei Li, Dr. Duane D. Miller, Dr. John K. Buolamwini, and Dr. Evgueni Pinkhassik, for their suggestions, comments and guidance. I would like to acknowledge Dr. Jiuyu Liu for his suggestions and discussions on my synthetic work. I would like to thank Zhao Wang for his help in testing the compounds against melanoma cell lines to determine anti-tumor activity. I would also like to thank Dr. Shantaram Kamath for his work on the molecular modeling studies to identify the lead diazosulfonamide compound. At last I would like to thank Dr. Wenwei Lin and Dr. Jianjun Qi for their help and friendship. 


\begin{abstract}
Calpain is a class of intracellular cytoplasmic cysteine proteases. ${ }^{1}$ The enzyme participates in different intracellular signaling pathways that are mediated by $\mathrm{Ca}^{2+2}$. The two major isoforms of calpain universally distributed in most mammalian tissues are calpain 1 ( $\mu$-calpain) and calpain 2 (m-calpain). The exact in vivo function of the enzyme is not clear, but calpain has been implicated in a variety of physiological and pathological conditions, ${ }^{3}$ such as cancer, stroke, cardiac ischaemia, muscular dystrophy, cataract and Alzheimer's disease. Calpain inhibitors are therefore of interest as therapeutic agents and as biomedical tools.
\end{abstract}

Several potent calpain inhibitors isolated from natural sources as well as synthesized in the laboratory have been reported (Chapter 1.4). Unfortunately, most of the inhibitors show poor calpain selectivity, metabolic stability and cell permeability. In an attempt to discover new calpain inhibitors, structure-based virtual screening of the National cancer Institute's (NCI) led to the identification of diazosulfonamide $\mathbf{1}$ $(K \mathrm{i}=1.0 \pm 0.02 \mu \mathrm{M})$ as a new nonpeptide competitive inhibitor of $\mu$-calpain. Using $\mathbf{1}$ as our lead compound, we first explored the structural requirements of the compound that are important for potent calpain inhibition of calpain (Chapter 2). Secondly, derivatives of $\mathbf{1}$ were synthesized to test the hypothesis that introduction of an electrophilic group for covalent interaction with the catalytic site thiolate group of calpain would enhance inhibition of the enzyme. Thirdly, the anti-tumor potential of the compounds was determined by screening them against human and mouse melanoma cell lines (Chapter 3). Our data showed that the carboxylic acid and the thiazole groups of $\mathbf{1}$ are important for potent inhibition of calpain. It was also found that incorporation of electrophilic groups (aldehyde and alpha-ketoamide) into derivatives of 1 significantly enhanced $\mu$-calpain inhibition with $K_{\mathrm{i}}$ values ranging from $9 \mathrm{nM}$ to $500 \mathrm{nM}$ ). Sulfonamide-based peptidomimetic analogue 19 with $K_{\mathrm{i}}$ of 9 $\mathrm{nM}$ was the most potent calpain inhibitor of the series and was over 100 -fold more potent than the lead diazosulfonamide 1 . Five of the compounds inhibited melanoma cell growth with $\mathrm{GI}_{50}$ values ranging from $4 \mu \mathrm{M}$ to $22 \mu \mathrm{M}$. Compound 16 was the most effective anti-tumor agent $\left(\mathrm{GI}_{50} 4 \mu \mathrm{M}\right)$ of this series. 


\section{TABLE OF CONTENTS}

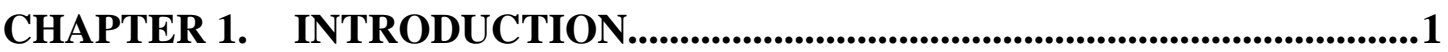

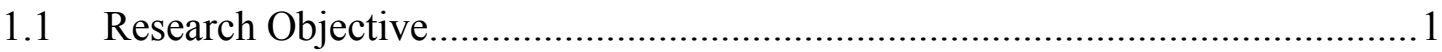

1.2 Overview of the Calpain Family of Cysteine Proteases.....................................2



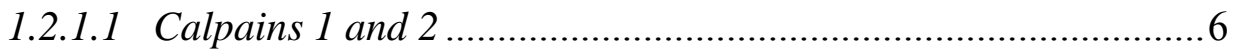

1.2.1.2 Calpain 4 (Calpain Small Subunit 1, capns1) .......................... 7

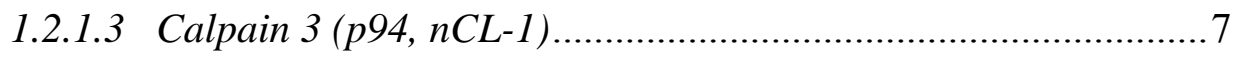

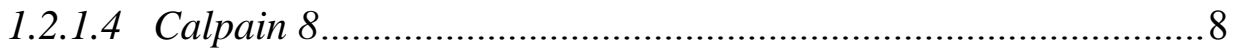

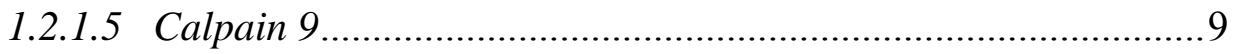

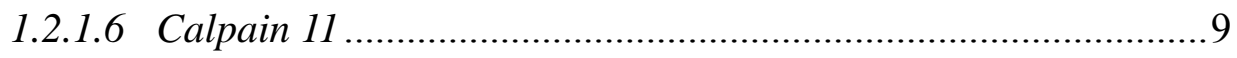

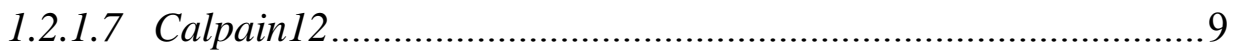

1.2.1.9 Calpain Small Subunit 2 (capns2) .......................................... 10

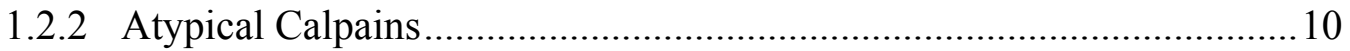

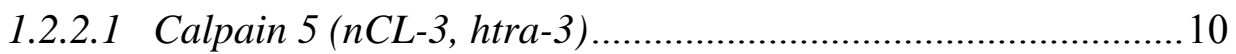



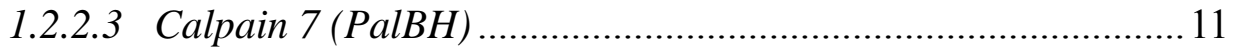

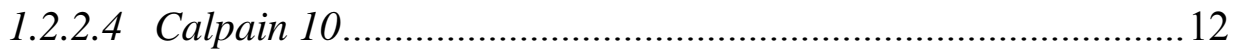

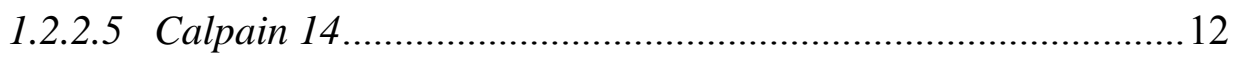

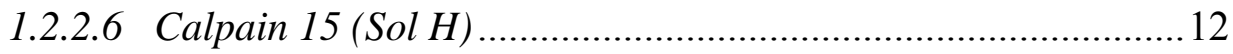

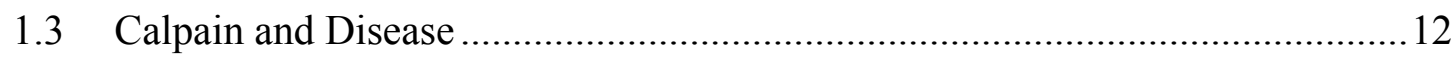

1.3.1 Limb-Girdle Muscular Dystrophy 2A (LGMD2A) ............................... 12

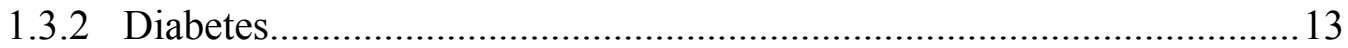

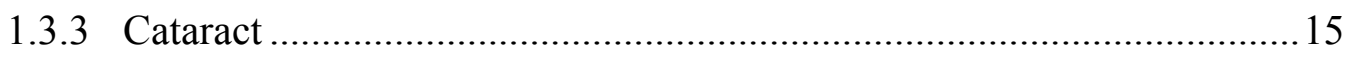

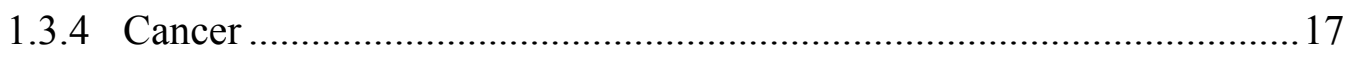

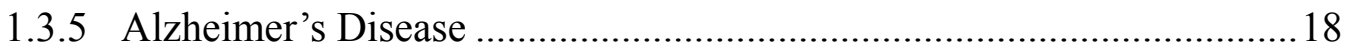

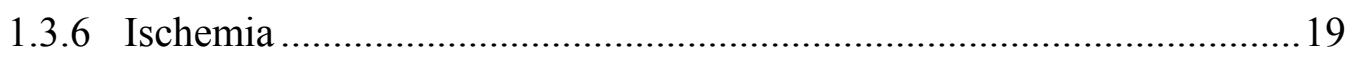

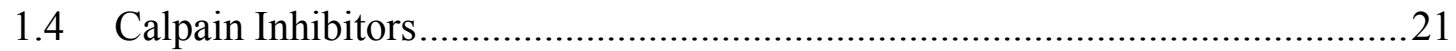

1.4.1 Active Site Directed Calpain Inhibitors ..............................................2 21

1.4.1.1 Irreversible Calpain Inhibitors ..............................................23

1.4.1.2 Reversible Calpain Inhibitors ...............................................23

1.4.2 Allosteric Calpain Inhibitors .............................................................22

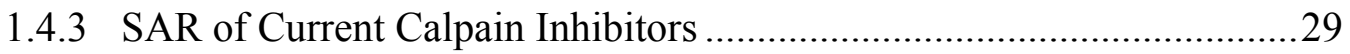

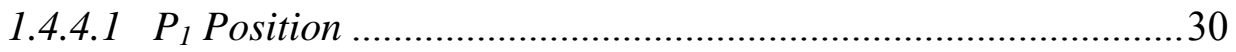

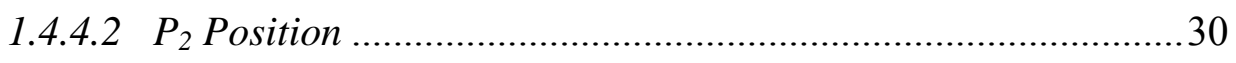



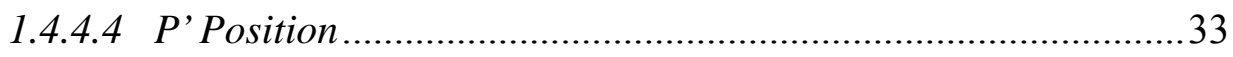

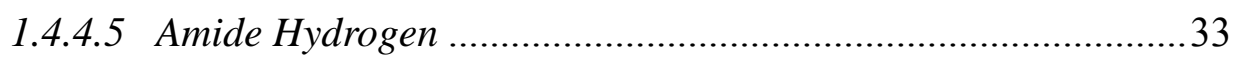




\section{CHAPTER 2. EXPLORATION OF DIAZOSULFONAMIDE}

DERIVATIVES AS CALPAIN INHIBITORS...................................................35

2.1 Structural Requirements Study of Diazosulfonamide 1 …..................................35

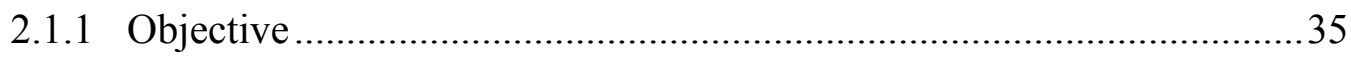

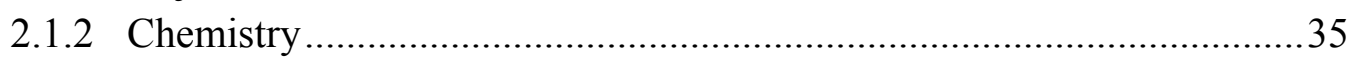

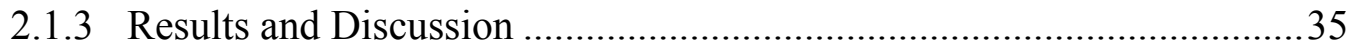

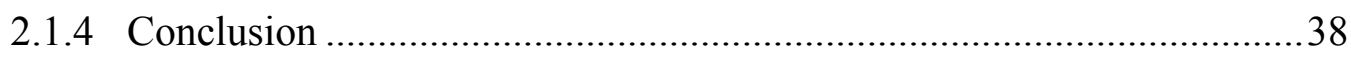

2.2 Synthesis of Sulfonamide-Based Peptidomimetic Calpain Inhibitors .................38

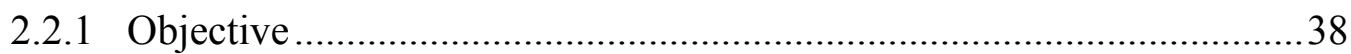

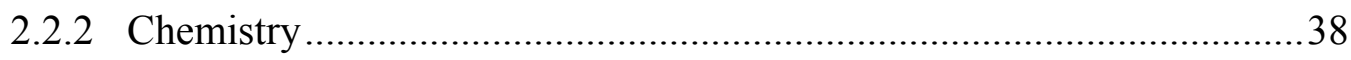

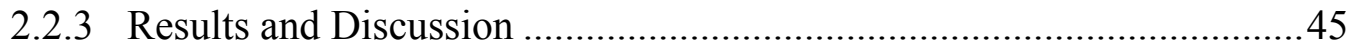

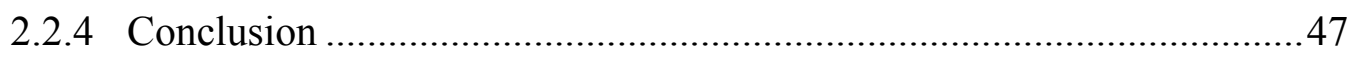

CHAPTER 3. DETERMINATION OF THE ANTI-TUMOR ACTIVITY OF THE SULFONAMIDE-BASED PEPTIDOMIMETIC CALPAIN

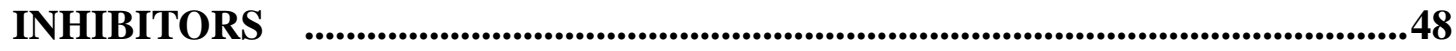

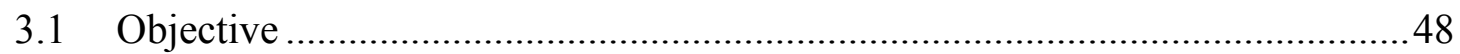

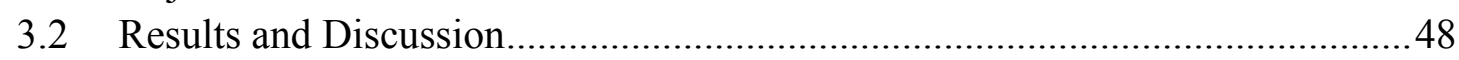

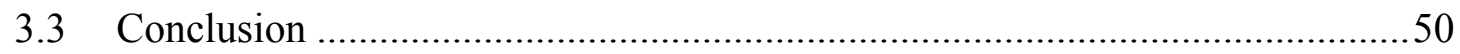

CHAPTER 4. EXPERIMENTAL SECTION ..................................................51

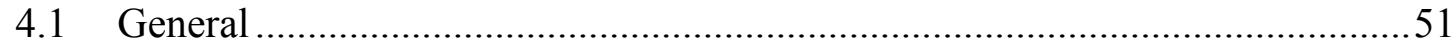

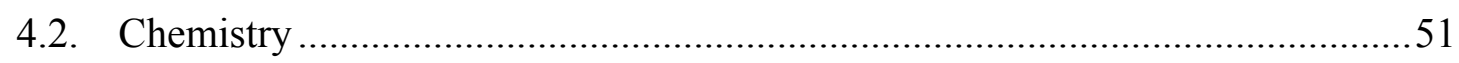

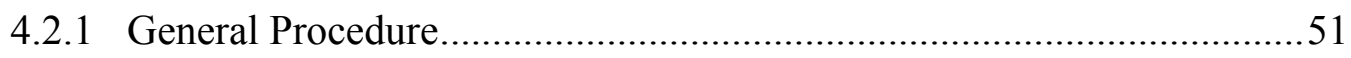

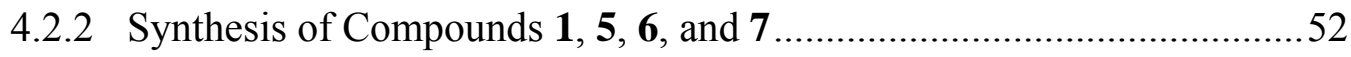

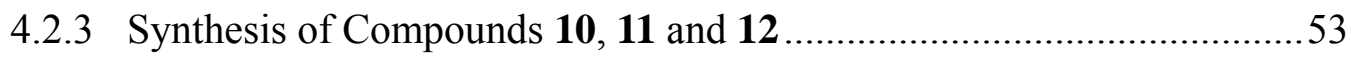

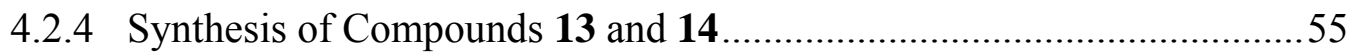

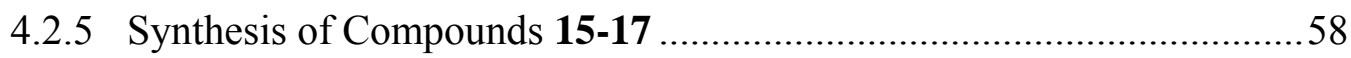

4.2.6 Synthesis of Compounds 18 and 19 ...................................................61

4.3 Determination of the Antiproliferative Activity of the Calpain Inhibitors.........63

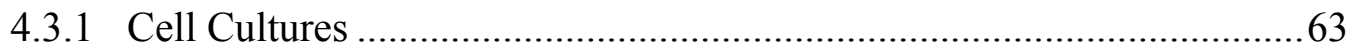

4.3.2 Cell Death Assay and $\mathrm{GI}_{50}$ Value Determination in Melanoma Cells....64

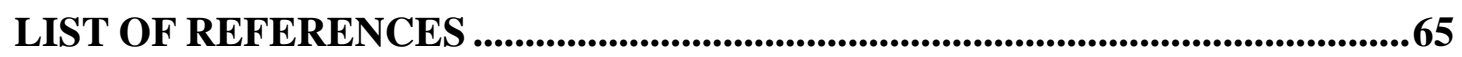

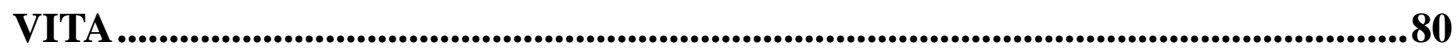




\section{LIST OF FIGURES}

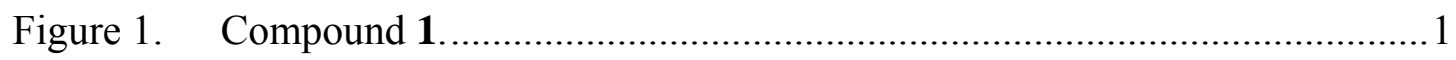

Figure 2. Schematic representation of the calpain family members. .......................5

Figure 3. Flow chart demonstrating the pathogenic consequences of CAPN3 deficiency. .................................................................................... 14

Figure 4. Proposed sites of action for calpain 10 in T2DM-related pathways........16

Figure 5. Calpain 1 and 2 in cerebral ischemia and traumatic brain injury.............20

Figure 6. Relationship among calpain, substrate and inhibitors...........................22

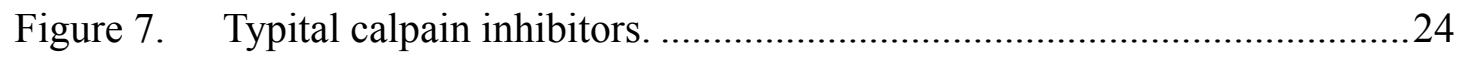

Figure 8. Functional groups of warheads in calpain inhibitors............................25

Figure 9. Domain structure of human hepatic calpastatin...................................2



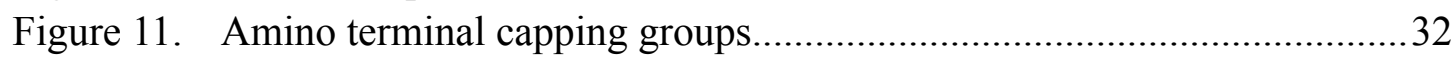



Figure 13. Structure and calpain inhibitory activity of compound $\mathbf{1}$ and its

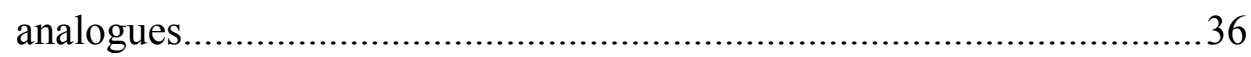

Figure 14. Hydrogen-bonding interactions between calpain 1 and compound 1......37

Figure 15. Sulfonamide-based peptidomimetic compounds 10-19...........................39 


\section{LIST OF SCHEMES}

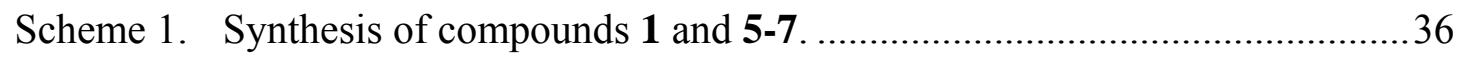

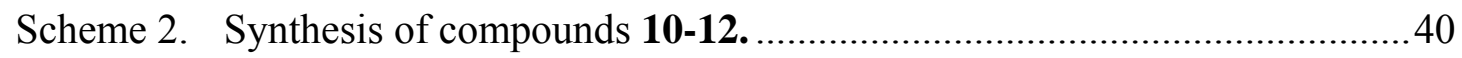

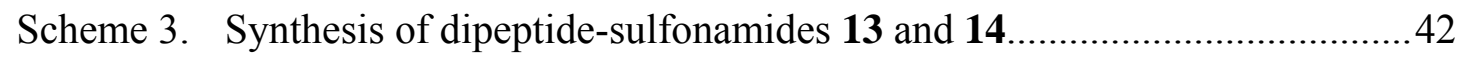

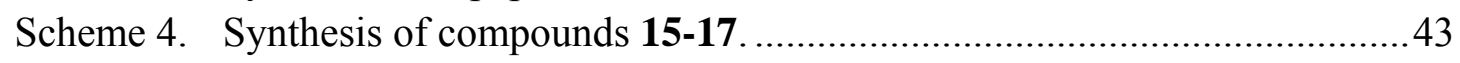

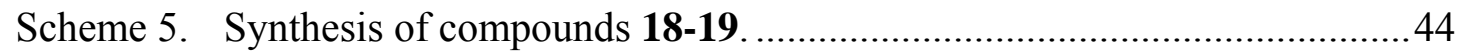




\section{LIST OF ABBREVIATIONS}

\begin{tabular}{|c|c|}
\hline $\mathrm{Abu}$ & 2-Aminobutyric acid \\
\hline $\mathrm{AD}$ & Alzheimer's disease \\
\hline Ala $(\mathrm{A})$ & Alanine \\
\hline AMPA & $\alpha$-Amino-3-hydroxy-5-methylisoxazole-4- propionic acid \\
\hline $\operatorname{Arg}(\mathrm{R})$ & Arginine \\
\hline $\operatorname{Asn}(\mathrm{N})$ & Asparagine \\
\hline Boc & Butoxycarbonyl \\
\hline BOP & $\begin{array}{l}\text { Benzotriazol-1-yloxytris-(dimethylamino)phosphonium } \\
\text { hexafluorophosphate }\end{array}$ \\
\hline $\mathrm{Br}$ & Bromo \\
\hline $\mathrm{CaM}$ & Calmodulin \\
\hline cAMP & Cyclic 3',5'-adenosine monophosphate \\
\hline Capn & Calpain gene \\
\hline CATM & Cataract with microphthalmia \\
\hline CDI & 1,1-Carbonyldiimidazole \\
\hline $\mathrm{CDK}(\mathrm{Cdk})$ & Cyclin dependent kinase \\
\hline $\mathrm{Cl}$ & Chloro \\
\hline CLL & Chronic lymphocytic leukemia \\
\hline CNS & Central nervous system \\
\hline Cys & Cysteine \\
\hline $\mathrm{DCC}$ & N,N'-dicyclohexylcarbodiimide \\
\hline DCM & Dichloromethane \\
\hline DIPEA & N,N-diisopropylethylamine \\
\hline DMEM & Dulbecco's Modification of Eagle's Medium \\
\hline DMF & Dimethyl formamide \\
\hline DMSO & Dimethyl sulfoxide \\
\hline $\mathrm{EC}$ & Enzyme Commission \\
\hline EDC & Ethylcarbodiimide hydrochloride \\
\hline EDTA & Ethylenediaminetetraacetic acid \\
\hline EGF & Epidermal growth factor \\
\hline ESI & Electron spray ionization \\
\hline EST & Expressed Sequence Tags \\
\hline EtOAc & Ethyl acetate \\
\hline $\mathrm{F}$ & Fluoro \\
\hline FBS & Fetal Bovine Serum \\
\hline $\mathrm{Gln}(\mathrm{Q})$ & Glutamine \\
\hline Gly (G) & Glycine \\
\hline Glu (E) & Glutamic acid \\
\hline $\mathrm{H}$ & Hydrogen \\
\hline His $(\mathrm{H})$ & Histidine \\
\hline $\mathrm{Hr}$ & Hour \\
\hline
\end{tabular}




\begin{tabular}{|c|c|}
\hline $\mathrm{H}_{2} \mathrm{O}$ & Water \\
\hline HBTU & $\begin{array}{l}\text { O-(Benzotriazol-1-yl)-N,N,N',N'-tetramethyluronium } \\
\text { hexafluorophosphate }\end{array}$ \\
\hline $\mathrm{HCl}$ & Hydrochloric acid \\
\hline HOBT & Hydroxybenzotriazole \\
\hline I & Iodo \\
\hline $\mathrm{I} / \mathrm{R}$ & Ischemia-reperfusion \\
\hline $\mathrm{IC}_{50}$ & Inhibitory concentration \\
\hline IDDM & Insulin dependent diabetes mellitus \\
\hline IR & Infrared spectra \\
\hline IS & Insertion sequences \\
\hline Ki & Inhibitor dissociation constant \\
\hline L-chain & Long subunit chain \\
\hline $\mathrm{LC} / \mathrm{MS}$ & Liquid chromatography/Mass spectrometry \\
\hline Leu (L) & Leucine \\
\hline LGMD & Limb girdle muscular dystrophy \\
\hline $\mathrm{LiAlH}_{4}$ & Lithium aluminium hydride \\
\hline $\mathrm{LiBH}_{4}$ & Lithium borohydride \\
\hline LTP & Long-term potentiation \\
\hline M & Micromole per liter \\
\hline MD & Muscular dystrophy \\
\hline $\mathrm{MeOH}$ & Methanol \\
\hline $\operatorname{Met}(\mathrm{M})$ & Methionine \\
\hline $\mathrm{MgSO}_{4}$ & Magnesium sulfate \\
\hline $\mathrm{mM}$ & Millimolar \\
\hline MMMTS & Malignant mullerian mixed tumors \\
\hline MS & Mass spectrometry \\
\hline $\mathrm{NaHSO}_{3}$ & Sodium hydrogen sulfite \\
\hline $\mathrm{NaOH}$ & Sodium hydroxide \\
\hline $\mathrm{Na}_{2} \mathrm{SO}_{4}$ & Sodium sulphate \\
\hline $\mathrm{Na}_{2} \mathrm{~S}_{2} \mathrm{O}_{3}$ & Sodium thiosulphate \\
\hline NCI & National cancer institute \\
\hline $\mathrm{nCL}$ & Novel calpain large subunit \\
\hline NIDDM & Non-insulin dependent diabetes mellitus \\
\hline NIH & National institutes of health \\
\hline Nle & Norleucine \\
\hline NMDA & N-methyl D-aspartate \\
\hline NMM & N-methyl morpholine \\
\hline NMR & Nuclear magnetic resonance \\
\hline$(\mathrm{o}-\mathrm{Tol})_{3} \mathrm{P}$ & Tris(2-methylphenyl)phosphine \\
\hline $\mathrm{Pd}(\mathrm{OAc})_{2}$ & Palladium(II) acetate \\
\hline Phe (F) & Phenylalanine \\
\hline $\mathrm{PKC}$ & Protein kinase $\mathrm{C}$ \\
\hline PL & Phospholipase \\
\hline
\end{tabular}




$\begin{array}{ll}\text { Pro }(\mathrm{P}) & \text { Proline } \\ \text { KCN } & \text { Potassium cyanide } \\ \text { RT } & \text { Room temperature } \\ \text { S-chain } & \text { Short subunit chain } \\ \text { SAR } & \text { Structure activity relationship } \\ \text { SCC } & \text { Squamous cell carcinoma } \\ \text { SEM } & \text { Standard error of mean } \\ \text { Ser (S) } & \text { Serine } \\ \mathrm{SO}_{3} & \text { Sulfur trioxide } \\ \mathrm{SOCl}_{2} & \text { Thionyl chloride } \\ \text { SRB } & \text { Sulforhodamine B } \\ \text { T1DM } & \text { Type I diabetes mellitus } \\ \text { T2DM } & \text { Type 2 diabetes mellitus } \\ \text { TBI } & \text { Traumatic brain injury } \\ \text { TCA } & \text { Trichloroacetic acid } \\ \text { TFA } & \text { Trifluoroacetic acid } \\ \text { THF } & \text { Tetrahydrofuran } \\ \text { Thr (T) } & \text { Threonine } \\ \text { TLC } & \text { Thin layer chromatography } \\ \text { Tyr (Y) } & \text { Tyrosine } \\ \text { Val (V) } & \text { Valine }\end{array}$




\section{CHAPTER 1. INTRODUCTION}

\subsection{Research Objective}

Calpain is a class of intracellular cytoplasmic cysteine proteases ${ }^{1}$ that participates in different intracellular signaling pathways mediated by $\mathrm{Ca}^{2+}$. The precise in vivo function of calpain is not completely understood but the enzyme has attracted considerable attention because of its implication in a number of physiological and pathological conditions such as cancer, stroke, and Alzheimer's disease. ${ }^{1,3}$ Hence, potent and selective calpain inhibitors are attractive as therapeutic agents and as biomedical tools. ${ }^{4}$

Potent calpain inhibitors have been discovered in the past decade and the most potent inhibitors are peptidomimetic compounds such as MDL-28170 ${ }^{5-8}$ and SJA-6017, ${ }^{9-12}$ which display calpain inhibitory activities in the nanomolar range. Nonpeptide calpain inhibitors have also been published but the calpain inhibitory activities of such compounds, unlike the peptidyl inhibitors, are in the micromolar range. Nonetheless, nonpeptide calpain inhibitors are still attractive because of their high selectivity and metabolic stability.

The problems of current calpain inhibitors are selectivity, cell permeability and metabolic stability. Several methods have been used to address the deficiencies. Some functional groups, such as benzyloxycarbonyl, sulfonyl, alkanoyl, substituted benzoyl, naphthoyl, xanthines, ${ }^{13}$ and pyridineethanol, ${ }^{9}$ have been used as $\mathrm{N}$-terminal capping groups to improve potency, selectivity and solubility. Different $\alpha$-ketone carbonyl groups have been incorporated at the $\mathrm{P}_{1}$ ' position to explore activity. ${ }^{14}$ Weakly basic groups have also been introduced at the $\mathrm{P}_{1}$ ' position to increase solubility. ${ }^{15}$ However, discovery of calpain inhibitors that incorporate potency, selectivity, metabolic stability, and adequate aqueous solubility within the same molecule is still a formidable challenge. Recent crystallographic data showing the active site structure of calpain with/without calpain inhibitors have made possible the development of potent and selective calpain inhibitors. Based on the X-ray crystal structure of the $\mu$-calpain, virtual screening of the NCI compound library coupled with enzymological evaluation led to the identification of diazosulfonamide $\mathbf{1}$ ( $\mathrm{Ki}=$ $1.0 \pm 0.02 \mu \mathrm{M}$, Fig. 1) as a new nonpeptide competitive inhibitor of $\mu$-calpain.

Sulfonamides have long been used as anti-infective agents in humans so this class of compounds is a good lead for optimization to afford novel inhibitors of $\mu$-calpain.

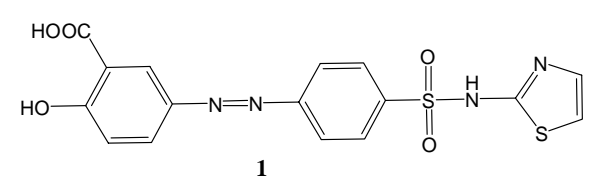

Figure 1. Compound 1. 
Based on the identification of $\mathbf{1}$, the objectives of this research were to (a) determine the structural requirements of diazosulfonamide 1 that are important for calpain inhibition as a prelude to the synthesis of novel sulfonamide-based peptidomimetic calpain inhibitors; (b) synthesize sulfonamide-based peptidomimetic calpain inhibitors; (c) assess the antiproliferative activity of the compounds since calpain has been implicated in carcinogenesis.

\subsection{Overview of the Calpain Family of Cysteine Proteases}

Calpain (EC 3.4.22.17) ${ }^{16,17}$ is a member of the cysteine protease family, which has nucleophilic thiol group at active site. It is named because typical calpain possesses a calmodulin-like calcium-binding domain, "cal-", and a papain-like cysteine protease domain, "-pain". ${ }^{18}$ Calpain was first observed in the soluble fraction of rat brain extracts by Guroff ${ }^{19}$ in 1964 and requires $\mathrm{Ca}^{2+}$ for activity. Now crystal structures of calpain $1^{20}$ and calpain $2^{21-23}$ from human are available.

Numerous isoforms of calpain have been identified, widely distributed from mammals to invertebrate, fungi, yeast, and bacteria. ${ }^{17}$ To date, sixteen different calpain isoforms have been identified in mammals ${ }^{21,24}$ (Table 1) and could be classified into two groups, "typical" calpains and "atypical" calpains, based on whether or not they possess EF-hand motifs on the carboxyl terminal ${ }^{24,25}$ (Figure 2). Two typical and ubiquitously distributed mammalian calpains are calpain 1 ( $\mu$-calpain), which requires micromolar concentration of calcium for activation in vitro, and calpain 2 (m-calpain), which requires millimolar concentrations of calcium. $^{18}$

Calpain is also found in a wide variety of tissues, including skeletal muscle, cardiac muscle, brain, kidney, lung, liver, and adipose tissues. ${ }^{26}$ The physiological or pathological regulation of calpain in these tissues is intricate and not well understood but it is acknowledged that calpain can cleave many intracellular signaling and structural proteins which play important roles in physiological or pathological conditions. Known calpain substrates include cytoskeletal and structural proteins (spectrin, microtubule-associated protein-2, tau factor, $\alpha$-actinin, fodrin, dystrophin, tubulin), membrane bound receptors and proteins (EGF receptor, AMPA receptor, G-proteins, anion channel), calmodulin binding proteins (calcium pump, inositol 1,4,5-trisphosphate kinase), myofibrillar proteins (troponin I, troponin T, myosin), transcription factors (c-fos, c-jun) and some other important enzymes (protein kinase C, 3-hydroxy-3-methylglutaryl-CoA reductase, cAMP-dependent kinase). ${ }^{27,28}$ The roles of the calpain substrates at pathological conditions have been studies but not well understood. But calpain has been implicated in muscular dystrophy, cataract, stroke, ischaemia, brain trauma, Alzheimer's disease, diabetes, and cancer. ${ }^{27}$ As calpain is becoming an attractive therapeutic target, identification of calpain inhibitors is necessary. 
Table 1. Human calpain expression profiles and diseases.

\begin{tabular}{|c|c|c|c|}
\hline Name & Typical/Atypical & Tissue Expression & Diseases \\
\hline Calpain 1 & Typical & Ubiquitous & $\begin{array}{l}\text { Huntington's disease, cataracts, stroke, muscular dystrophy, } \\
\text { traumatic brain injury, spinal cord njury, alzheimer, cancer, } \\
\text { multiple sclerosis, Lou Gehrig's disease, osteopenia }\end{array}$ \\
\hline Calpain 2 & Typical & Ubiquitous & $\begin{array}{l}\text { Cataracts, muscular dystrophy, stroke, spinal cord injury, } \\
\text { traumatic brain injury, Alzheimer, Parkinson, } \\
\text { atherosclerosis, multiple sclerosis, Lou Gehrig's disease, } \\
\text { cancer, psoriasis }\end{array}$ \\
\hline Calpain 3 & Typical & Skeletal muscle, lens, retina & Limb girdle muscular dystrophy 2A (LGMD2A), cataracts \\
\hline Calpain 4 & Typical & Ubiquitous & \\
\hline Calpain 5 & Atypical & Ubiquitous & $\begin{array}{l}\text { Huntington's disease polycystic ovarian syndrome,metabolic } \\
\text { syndrome }\end{array}$ \\
\hline Calpain 6 & Atypical & Placenta & \\
\hline Calpain 7 & Atypical & Ubiquitous & Huntington's disease \\
\hline Calpain 8 & Typical & Stomach mucosa & \\
\hline Calpain 9 & Typical & Digestive tract & Gastric cancer \\
\hline Calpain 10 & Atypical & $\begin{array}{l}\text { Ubiquitous, and tissue specific } \\
\text { isoforms }\end{array}$ & $\begin{array}{l}\text { Huntington's disease, cataracts (?), diabetes mellitus, } \\
\text { atherosclerosis, metabolic syndrome }\end{array}$ \\
\hline Calpain 11 & Typical & Testis & \\
\hline
\end{tabular}


Table 1 (continued).

\begin{tabular}{cccc}
\hline Name & Typical/Atypical & Tissue Expression & Diseases \\
\hline Calpain 12 & Typical & Ubiquitous & Alzheimer (?) \\
Calpain 13 & Typical & Testis/lung & \\
Calpain 14 & Atypical & Ubiquitous & CATM (hereditary cataract with microphthalmia) (?) \\
Calpain 15 & Atypical & Ubiquitous & \\
Calpain small subunit 2 & Typical & N.D. & \\
& & & \\
\hline
\end{tabular}

N.D. - not determined

Sources:(1) Saez, M. E.; Ramirez-Lorca, R.; Moron, F. J.; Ruiz, A. The therapeutic potential of the calpain family: new aspects. Drug Discov Today 2006, 11, 917-923. ${ }^{24}$ Modified with permission from Elsevier Ltd. (2) Carragher, N. O. Calpain inhibition: a therapeutic strategy targeting multiple disease states. Curr Pharm Des 2006, 12, 615-638. ${ }^{25}$ Modified with permission from Bentham Science Publishers Ltd. 


\section{Typical calpains}

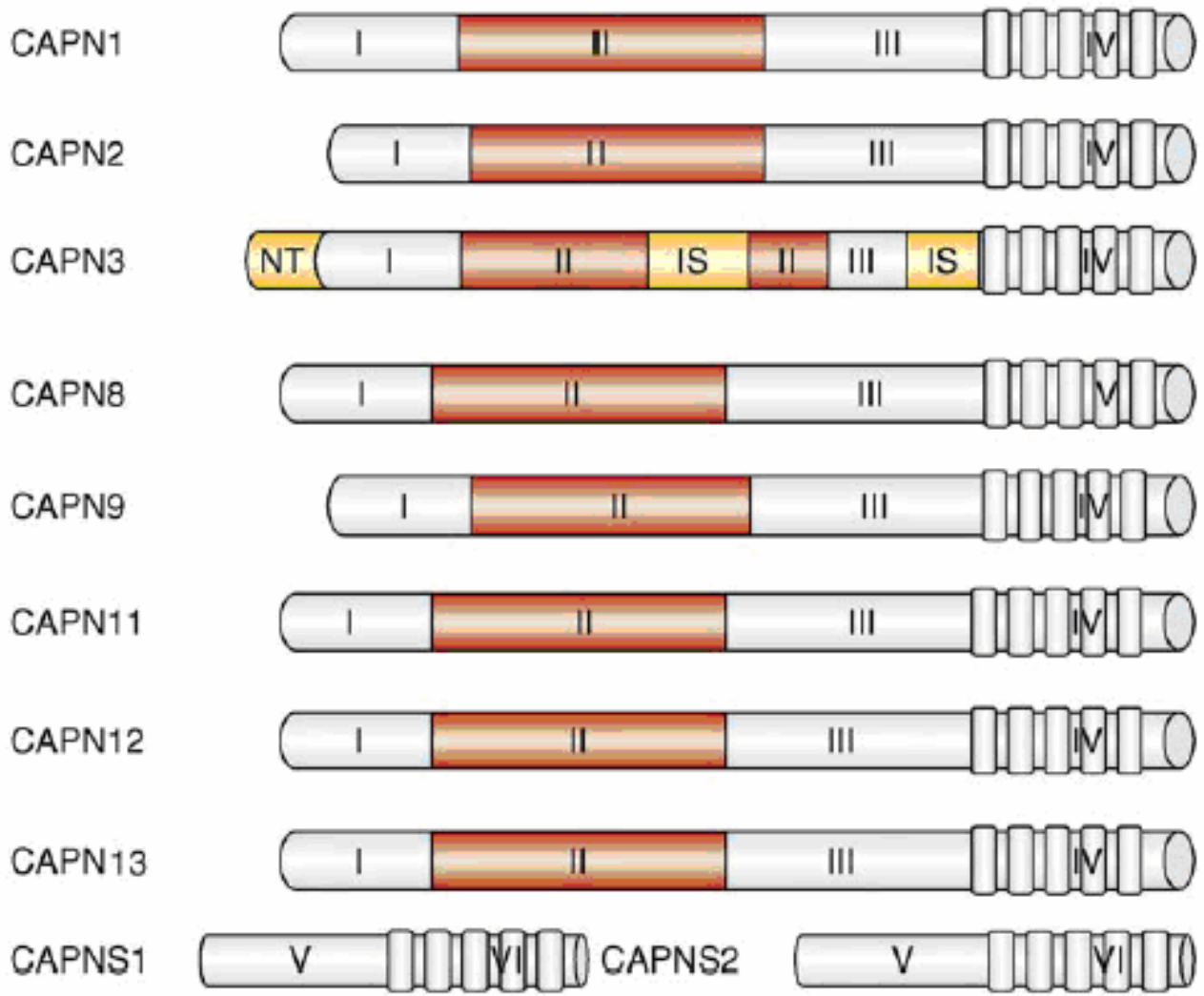

Atypical calpains

CAPN7

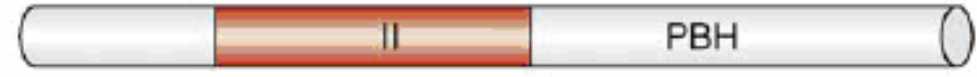

CAPN 14

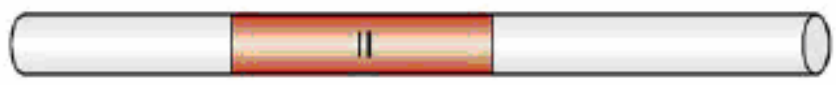

CAPN15

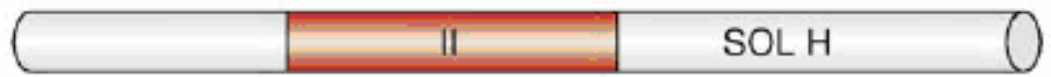

CAPN5

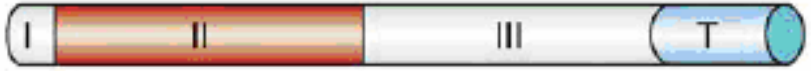

CAPN6

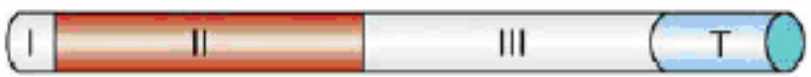

CAPN10

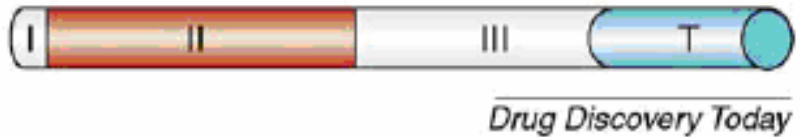

Figure 2. Schematic representation of the calpain family members.

Source: Saez, M. E.; Ramirez-Lorca, R.; Moron, F. J.; Ruiz, A. The therapeutic potential of the calpain family: new aspects. Drug Discov Today 2006, 11, 917-923. ${ }^{24}$ Adapted with permission from Elsevier Ltd. 
It is important to note that calpain small subunit 2 was named as calpain14. ${ }^{29}$ But after finding two new calpain genes, which are named as calpain13 and calpain14, old calpain 13 was named as calpain 15 and calpain small subunit 2 is not calpain $14 .^{24,25}$ Not all calpain isoforms have been isolated at protein level, most of them have only been identified at the messenger ribonucleic acid (mRNA) level and only have predicted protein structure. ${ }^{23}$

\subsubsection{Typical Calpains}

Typical calpains, also named as EF-hand subfamily of calpains, include calpain $1,2,3,4,8,9,11,12,13$ and calpain small subunit 2 . They posses a $\mathrm{Ca}^{2+}$ binding EF-hand structure at the carboxy terminus. ${ }^{25}$ EF-hand structure is a helix-loop-helix, calcium binding motif, in which two helices pack together at an angle of approximately 90 degrees, separated by a loop region, where calcium binds. The "EF" notation for the motif resulted from the structure of parvalbumin, in which the "E" and "F" helices were originally identified to form this calcium binding motif. ${ }^{30}$

\subsubsection{Calpains 1 and 2}

Calpain 1 and calpain 2, also known as $\mu$-calpain and m-calpain, respectively, are the most extensively characterized members of the calpain superfamily. A large amount of calpain literature, including inhibitors, structure, and animal assays focus on these two isoforms. Both of them are ubiquitously distributed in mammalian cells. Calpain 1 requires micromolar concentrations of $\mathrm{Ca}^{2+}$ for activity in vitro whereas calpain 2 needs millimolar levels of $\mathrm{Ca}^{2+}$. They function as hetero-dimers consisting of a similar large catalytic subunit and a common regulatory subunit (Figure 2). The large subunit is distinct for each calpain but the small subunit is identical. Calpain 1 has the large $82 \mathrm{kDa}$ catalytic subunit and calpain 2 encodes the $80 \mathrm{kDa}$ catalytic subunit. Both calpain 1 and calpain 2 associate with the small $28 \mathrm{kDa}$ regulatory subunit. Calpain 1 and calpain 2 share approximately $60 \%$ sequence homology. ${ }^{25}$

The large subunit of calpain 1 and 2 can be sub-divided into four domains (I-IV) based on their amino-acid sequence. ${ }^{25}$ Domain I (amino acids 1-87 in calpain 1 and 1-76 in calpain 2) is the N-terminal portion of the large subunit and is highly conserved between different species. ${ }^{25}$ However, this region does not share any significant sequence homology with any other polypeptide and its precise function remains to be determined. ${ }^{25}$ Domain I also contains the autolysis site and may be cleaved during the autolytic activation, which significantly increases sensitivity to $\mathrm{Ca}^{2+} \cdot{ }^{21}$ Domain II (amino acids 88-327 in calpain 1 and 77-316 in calpain 2) is the catalytic protease domain which contains a catalytic triad (Cys-His-Asn) for substrate hydrolysis. The triad is composed of Cysteine (Cys), Histidine (His) and Asparagine (Asn) residues. Cys is located at residue 115 for human calpain 1 and 105 for human 
calpain 2 . The crystal structure of calpain 2 shows that domain II can be divided into two sub-domains (IIa and IIb) that are spatially separated in the absence of calcium. ${ }^{22}$ The active site residue cysteine is located on subdomain IIa whereas histidine and asparagine are located on subdomain IIb. ${ }^{25}$ Domain III (amino acids 328-569 in calpain 1 and 317-555 in calpain 2) is the linker between the catalytic domain II and the $\mathrm{Ca}^{2+}$-binding domain IV. It does not have obvious sequence homology to any other protein $^{21}$. But it has eight strands of $\beta$-sheets with a topology similar to the $\mathrm{C} 2$ domain, which is found in such proteins as protein kinase $\mathrm{C}$ and phospholipase $\mathrm{C} .{ }^{21} \mathrm{C} 2$ domain can bind phospholipids in a $\mathrm{Ca}^{2+}$-dependent manner and thus domain III is speculated to regulate calpain activity by involvement in electrostatic interactions with domain II. ${ }^{25}$ Besides, when $\mathrm{Ca}^{2+}$ binds to domain IV, domain III changes its tertiary structure to increase the accessibility of the active site. ${ }^{31}$ Domain IV (amino acids 570-714 in calpain 1 and 556-699 in calpain 2) is a calmodulin-like domain with five EF hand motifs. The first four EF hand motifs are thought to act as calcium binding sites while the fifth $\mathrm{COOH}$-terminal EF-hand is involved in dimerization with the $28 \mathrm{kDa}$ small subunit (calpain 4). ${ }^{25}$

\subsubsection{Calpain 4 (Calpain Small Subunit 1, capns1)}

Calpain 4 is well known as the small or regulatory subunit of calpains 1 and 2, and it is also known as calpain small subunit 1. It is composed of the $\mathrm{NH}_{2}$-terminal domain V and the COOH-terminal domain VI. ${ }^{32}$ Domain V (amino acids 715-781 in calpain 1 and 700-767 in calpain 2) is highly rich in glycine residues, containing about $30 \%$ glycine residues, and is referred to as a hydrophobic domain. The function of domain $\mathrm{V}$ has not yet been elaborated and it may act as a membrane anchor. ${ }^{33}$ It is proposed that anchoring to membrane is a key step in the activation of the enzyme in vivo. $^{34,35}$ Domain VI (amino acids 782-984 in calpain 1 and 768-970 in calpain 2) is connected to domain $\mathrm{V}$ by a polyproline linker. It has about $50 \%$ sequence identity to domain IV and also contains five EF hand motifs, the first four of which bind calcium ions while the fifth can interact with its counterpart in another calpain molecule to form a homodimer or interact with the catalytic domain of calpain 1 or calpain $2 .^{25,36,37}$

\subsubsection{Calpain 3 (p94, nCL-1)}

Calpain 3 gene (capn3), named as p94, ${ }^{38}$ encodes an 821 amino acid protein, ${ }^{39}$ which has different sequence with conventional calpain 1 and 2. mRNA expression of calpain 3 can be detected. However, calpain 3 protein is hardly detectable because it autolyzes rapidly after its translation with an estimated half-life of 27 minutes. ${ }^{38}$ Calpain 3 is also known as novel calpain large subunit 1 (nCL-1), because its large subunit was different from calpain 1 and 2 , and was the first discovered structure outside of the conventional calpain 1 and $2 .^{29}$ 
Human calpain 3 shows significant sequence homology with the large subunit of human calpain 1 and $2,54 \%$ and $51 \%$ respectively, ${ }^{40}$ and can also be divided into four similar domains. As calpain 1 and 2, domain II contains the active site Cys, His, Asn residues necessary for catalysis. But unlike calpains 1 and 2, calmodulin-like calcium-binding domain $\mathrm{IV}^{40}$ does not bind nor interact with domain VI of calpain $4 .^{2}$

Besides, calpain 3 is over 100 amino acid residues longer and has three unique sequences (NS, IS1 and IS2) compared to the conventional calpain. NS, which is at the N-terminal specific region of domain I, is about 60 residues in length and is rich in proline $(\mathrm{P})$ residues at the amino terminal end. ${ }^{41}$ The precise function has not yet been clarified but it is believed to play an important role in the overall tertiary structure of

the enzyme. ${ }^{2}$ IS1, located in the middle of domain II, has 62 amino acid residues. ${ }^{38}$ Its function has not been elucidated, but may be involved in regulatory activity. ${ }^{42,43}$ IS2, located at the C-terminal of domain III, has 77 amino acid residues. ${ }^{38}$ It is rich in lysine residues at the amino terminal end and possesses a nuclear localization-like sequence, which suggests that calpain 3 could play a role in nuclear localization. ${ }^{41}$

In muscle, mRNA expression of calpain 3 is at least 10 fold higher than that of calpain 1 and 2. ${ }^{38,40,41}$ A disruption of the calpain 3 gene resulted in limb girdle muscular dystrophy type 2A (LGMD2A), suggesting that the protein may have a specific role in the physiological functions of the skeletal muscle. ${ }^{44}$ Three splice variants of calpain 3, Lp82, Lp85, and Rt88, have been detected in rat visual system. These variants of calpain 3 are believed to be involved in lens development and maturation. ${ }^{45-47}$

\subsubsection{Calpain 8}

Calpain 8, also known as nCL-2 (novel calpain large subunit 2), was found by searching rat cDNA libraries of various tissues. ${ }^{29}$ The mRNA level of calpain 8 is predominantly expressed in the stomach, and weak expression is observed in the small intestine, ${ }^{2,48}$ heart and skeletal muscle. ${ }^{2}$ Like calpain 3, calpain 8 does not associate with the small regulatory subunit. ${ }^{49}$ But calpain 8 does not have the NS, IS1, and IS2 sequences which is specific for calpain 3. Calpain 8 has high sequence homology to the domain structure of conventional calpain. ${ }^{50}$ The large subunit of calpain 8 is $58 \%$ homologous to human calpain 1 and $61 \%$ homologous to calpain $2 .{ }^{51}$ Calpain 8 contains 703 amino acid residues and can also be divided into four domains. Domain II, which has over $70 \%$ similarity to $\mathrm{m}$ - and $\mu$-calpains, is the most conserved. Domain IV has four EF-hand structures.

Calpain 8 can be alternatively splice to give nCL-2', which contains 381 amino acid residues. nCL-2' has identical large subunit as nCL-2 but two thirds of domain III and calcium binding domain IV are missing. ${ }^{29}$ Therefore, $\mathrm{nCL}-2$ ' is assigned to be 
a member of the non-EF hand subfamily. The mRNA level of both nCL-2 and nCL-2' expressed in the stomach are almost equal with calpain 1 and 2 . This suggests that nCL-2 and nCL-2' may play an important role in the stomach as conventional calpains 1 and 2 in the stomach. ${ }^{48}$

\subsubsection{Calpain 9}

Calpain 9, also known as nCL-4 (novel calpain large subunit 4), was identified by the screening of rat cDNA. It comprises 690 amino acids and is expressed predominantly in the digestive organs such as stomach and small intestine, and in the uterus. $^{2}$ It has a total sequence identity of $54 \%$ with human calpain $1,51 \%$ with human calpain $2,52 \%$ with rat calpain 8 , and $55 \%$ with human calpain 3 when the NS, IS1, and IS2 regions are excluded. ${ }^{48}$ The expression of calpain 9 is downregulated in gastric cancer tissues and cell lines. ${ }^{52}$ The depletion of calpain 9 by antisense RNA results in cell transformation and tumourigenesis in murine NIH 3 T3 fibroblasts. ${ }^{53,54}$ These indicate that calpain 9 may function as a tumour suppressor.

\subsubsection{Calpain 11}

Calpain 11 was discovered by a search of the protein sequences in the commercially available INCYTE EST database. The predicted calpain 11 protein is a 702 amino acid protein and has a total sequence identity of $58 \%$ with chicken $\mu / \mathrm{m}$-calpain and $54 \%$ with human calpain $1 .^{55}$ Domain II of calpain 11 contains $\mathrm{C}, \mathrm{H}$, and $\mathrm{N}$ amino acids to be a catalytic triad (Cys-His-Asn). Dmain IV has five calcium-binding sequences which suggest that calpain 11 could also possess calcium-binding ability. ${ }^{55}$ mRNA analysis of different tissues suggested that the highest level of Capn 11 is presented in spermatocytes during the later stages of meiosis. ${ }^{55,56}$ Testis-specific calpain 11 could be involved with testis-specific transcription factor regulation or germ cell apoptosis. ${ }^{55}$

\subsubsection{Calpain12}

Calpain 12 was discovered by searching the GenBank mouse EST database with protein sequences of known vertebrate calpains. ${ }^{57}$ Calpain 12 has 720 amino acids and predicted sequence has a homology of $40 \%$ with calpain $2 .{ }^{57} \mathrm{I} t$ can also be divided into four domains (I-IV), similar to conventional calpains. Calpain 12 has catalytic domain II and a $\mathrm{Ca}^{2+}$-binding domain IV. Domain II contains $\mathrm{C}, \mathrm{H}$, and $\mathrm{N}$ amino acids to be catalytic triad and domain IV has five calcium-binding sequences. RT-PCR analysis has shown that the CAPN12 gene is ubiquitously expressed but the highest amounts are found in cortex of the hair follicles. ${ }^{57}$ 


\subsubsection{Calpain13}

Calpain 13 is predominantly distributed in testis, like calpain 11 , and has also been detected in the lung. ${ }^{58}$ The functions and their eventual role in human diseases remain unexplored. ${ }^{24}$

\subsubsection{Calpain Small Subunit 2 (capns2)}

Calpain small subunit 2 is highly homologous $(63 \%)$ to small subunit 1 with fewer glycine residues in its domain $\mathrm{V}$ than small subunit $2 .{ }^{29}$ Its function is unclear. $^{17,24}$

\subsubsection{Atypical Calpains}

“Atypical" calpains (calpain 5, 6, 7, 10, 14 and15) do not possess a domain IV that contains EF-hand calcium binding sites at their carboxy terminus. It is unclear whether the atypical calpains require calcium for activity.

\subsubsection{Calpain 5 (nCL-3, htra-3)}

Calpain 5 (nCL-3, or htra-3) was identified by a search of the GenBank database with the amino acid sequence of domain II of human calpain $1 .{ }^{59}$ Calpain 5 is named as nCL- $3^{29}$ because it was the third novel large subunit identified. Calpain 5 is considered as htra-3 because it is the human homologue of tra-3. Domain I-III of calpain 5 has $35 \%$ similarity with the tra-3, which is a sex determination gene of the nematode. ${ }^{59}$

The predicted 634 amino acid sequence of calpain 5 has similar large subunits with calpains 1 and 2 from domain I to III and has a novel region termed domain T. Domain $\mathrm{T}$ does not have the conventional EF-hand motifs for $\mathrm{Ca}^{2+}$-binding as found in domain $\mathrm{IV}^{2}$ It is unclear whether calpain 5 is $\mathrm{Ca}^{2+}$-dependent.

The mRNA of calpain 5 is present in many tissues, but its highest expression is in the colon, small intestine, and testes. ${ }^{29}$ Since the calpain 5 gene is required for correct sexual development in hermaphrodites (e.g., nematodes), it is thought that calpain 5 plays a role in sex determination and development in humans. ${ }^{59}$ 


\subsubsection{Calpain 6}

Calpain 6 was identified by a search of the GenBank database with the amino acid sequence of domain II of human calpains 1 and $2 .{ }^{17}$ It is also known as CAPNX because of its location on the $\mathrm{X}$ chromosome.

The predicted amino acid sequence of calpain 6 has a similar domain II with calpains 1 and 2. The cDNA of calpain 6 shows that it does not have the active site cysteine residue but rather a nonfunctional lysine residue. ${ }^{29}$ As a result, the protein of calpain 6 is predicted to be protolytically inactive. ${ }^{59}$ The same thing was observed in mice. In addition to the absence of cysteine residue, the mouse mRNA of calpain 6 does not translate an active site His residue in domain II either. ${ }^{49}$ Calpain 6 has $47 \%$ homology to calpain 5. ${ }^{17,60}$ Both calpain 6 and calpain 5 lack the $\mathrm{Ca}^{2+}$ binding domain $\mathrm{IV}$, and is replaced with a T-domain. The function of domain $\mathrm{T}$ is still unknown.

The physiological and pathological roles of calpain 6 remain to be determined. mRNA of calpain 6 is expressed in skeletal, heart muscles and in specific cells of the lung, kidney and various epithelial cell types. ${ }^{56}$ Out of 50 tissues tested, the highest level of calpain 6 mRNA was expressed only in the placenta, which suggests that the protein could play a role in the development process. ${ }^{29}$ Calpain 6 is also speculated to play a role in sex determination and development because of its similarity to tra 3 and calpain 5, and due to its location on human X chromosome. ${ }^{29}$

\subsubsection{Calpain 7 (PalBH)}

Calpain 7 was identified by a search of the EST database at the National Center for Biotechnology Information with nucleic acid and amino acid sequences of known vertebrate calpains. Its predicted 813 amino acid protein product ${ }^{61}$ shares $26-35 \%$ identity to the rest of the calpain members. ${ }^{17,29,61}$ and has little homology in domains III and I of calpain 1 and $2 .{ }^{29}$ Domain II of calpain 7, which contains the active site C, $\mathrm{H}$, and $\mathrm{N}$ residues, is similar with conventional calpains (calpain 1 and 2). ${ }^{61,62}$ The carboxyl terminal domain shows no homology to either the calmodulin-like domain IV or to domain T of calpains 5 and $6^{61}$ but its carboxyl terminal end is homologous to the PalB fungal protease that is involved in alkaline ambient $\mathrm{pH}$ adaptation in the fungus Aspergillus nidulans. ${ }^{29}$ So calpain 7 is also known as the PalBH (PalB homologous domain).

Calpain 7 appears to be ubiquitously distributed but its exact function is unknown. The levels of calpain 7, along with other calpain family members, such as calpain 1, 5 and 10, are increased in Huntington's disease target-tissue culture and transgenic mouse models, suggesting that they might contribute to this neurological pathology. $^{24}$ 


\subsubsection{Calpain 10}

Calpain 10 was discovered and cloned during a search aimed at identifying type 2 diabetes susceptibility genes. ${ }^{60}$ The predicted protein sequence contains the catalytic triad $(\mathrm{C}, \mathrm{H}$, and $\mathrm{N})$ at active site. The $\mathrm{C}$-terminal of calpain 10 does not have EF-hand motifs as typical calpains and is homologous to domain $\mathrm{T}$ in calpain 5 and 6 .

High mRNA levels of calpain 10 are found in heart, pancreas, brain, liver, and kidney. Calpain 10 is thought to play a role in type 2 diabetes. ${ }^{63-66}$

\subsubsection{Calpain 14}

Calpain14 was reported on 2001 with calpain $13 .{ }^{58}$ However, the mRNA of calpain 14 could not be detected in any of the 76 tissues examined. Radiation hybrid mapping localized the gene within a region mapped to $2 \mathrm{p} 21-2 \mathrm{p} 22 .{ }^{58}$

\subsubsection{Calpain 15 (Sol H)}

A search of the human EST database showed that calpain 15 has $44 \%$ sequence homologue ${ }^{67}$ with sol, the embryo-specific Drosophila small optic lobe gene product ${ }^{29}$ hence the ubiquitously distributed human calpain 15 is sometimes referred as SolH. ${ }^{29}$

The predicted 1086 amino acid protein contains Cys, His, and Asn active site residues within a similar domain II region. ${ }^{29}$ Like Sol, predicted calpain 15 possesses five copies of a zinc-finger-like motif in its amino terminal portion ${ }^{67}$ instead of calmodulin-like domain IV.

Calpain 15 is expressed at low levels in most tissues. its role has not yet been fully determined, but calpain 15 gene has been implicated in a chromosomal translocation in a family affected by hereditary cataract with microphthalmia $(\mathrm{CATM}){ }^{24,68}$

\subsection{Calpain and Disease}

\subsubsection{Limb-Girdle Muscular Dystrophy 2A (LGMD2A)}

In 1954, Walton and Nattrass established limb-girdle muscular dystrophy (LGMD) as an entity distinct from other muscular dystrophies. ${ }^{69,70}$ In 1995, the European Neuromuscular Centre Workshop established more precise criteria for diagnosis and classification of LGMD, grouping the different subtypes according to 
their genetic characteristics. ${ }^{69}$ The designation for autosomal-dominant limb-girdle dystrophies is now LGMD1, whereas autosomal-recessive forms are LGMD2. ${ }^{69}$ Numerous reviews and individual reports suggest that autosomal recessive is much more common than autosomal dominant LGMD. Among patients with LGMD2, types 2A appears to be one of the more common subtypes. ${ }^{69}$ LGMD2A is an autosomal recessive form of the disease in which the muscle specific calpain 3 (also known as p94) is the primary cause. ${ }^{44}$

The onset of LGMD2A is usually in the second decade of life, although it has been documented to occur as early as age 2.5 and as late as age $49 .{ }^{71}$ The course of the disease is slow but progressive, leading to loss of ambulation by approximately 1 or 2 decades after diagnosis. Scapular winging and hip abductor sparing are two common features. ${ }^{71}$ At the current time, no effective treatment is available to patients with LGMD. ${ }^{69}$

Inactivating mutations in the calpain 3 gene are responsible for limb-girdle muscular dystrophy LGMD2A. ${ }^{72}$ Genetic quest for the etiologic gene of a cluster of LGMD patients in the southern part of the isle of La Réunion led to the initial mapping of the disease locus to the gene CAPN3, encoding the calpain 3 protease. $^{71}$ There are now over 280 documented distinct pathogenic CAPN3 mutations. These CAPN3 mutations span almost the entire length of the CAPN3 gene with no major predominant mutations. ${ }^{71}$ Of interest is the fact that numerous mutations lead to loss of calpain 3 protein, indicating that lack of this protease may lead to pathogenic consequences. $^{71}$

The exact mechanisms involved in the pathogenesis of LGMD2A are still unknown. Since calpain 3 is a protease with a potentially broad range of substrates, there is a high probability that it is involved in regulating multiple physiological processes. This diverse role for calpain 3 means that its absence or mutations in CAPN3 can affect many pathways in muscle cells. ${ }^{71}$ Hypothetical mechanism (Figure 3) was proposed to explain why the loss of proteolytic capability of calpain 3 might lead to cell dysfunction. Mutations in CAPN3 can lead to loss of proteolytic activity or loss of titin anchorage. The latter is likely to reduce regulation of proteolytic activity or to remove calpain 3 from its substrates. Loss of proteolysis of substrates can cause accumulation of proteins that can subsequently be damaged and then aggregate. These aggregates can impair proper muscle function and impair growth, leading to muscular dystrophy.

\subsubsection{Diabetes}

Diabetes mellitus is a metabolic disease which is characterized by high blood glucose levels because the body does not release or use insulin adequately. If untreated, it can lead to blindness, kidney and heart disease, stroke, loss of limbs and 


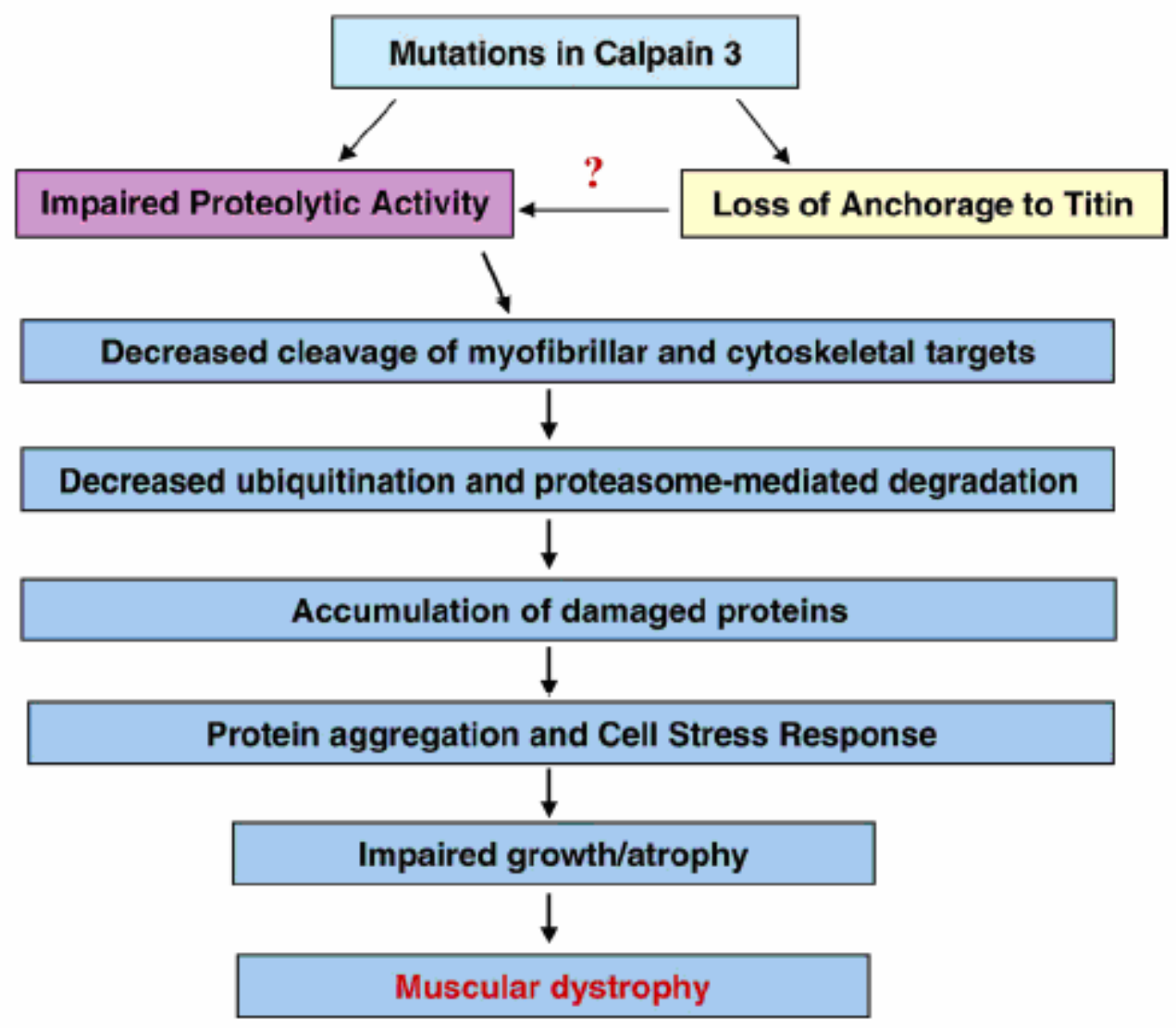

Figure 3. Flow chart demonstrating the pathogenic consequences of calpain 3 deficiency. Mutations in calpain 3 can lead to loss of proteolytic activity or loss of titin anchorage. The latter is likely to reduce regulation of proteolytic activity or to remove calpain 3 from its substrates. Loss of proteolysis of substrates can cause accumulation of proteins that can subsequently become damaged and then aggregate. These aggregates can impair proper muscle function and impair growth, leading to muscular dystrophy.

Source: Kramerova, I.; Beckmann, J. S.; Spencer, M. Molecular and cellular basis of calpainopathy (limb girdle muscular dystrophy type 2A). Biochim Biophys Acta 2007, 1772, 128-144. ${ }^{71}$ Adapted with permission from Elsevier Ltd. 
diabetes, is caused by autoimmune destruction of the $\beta$ cells of the pancreas, reduced life expectancy. ${ }^{60}$ Type I diabetes mellitus (T1DM), or insulin-dependent insulin-producing cells, rendering the pancreas unable to synthesize and secrete insulin. ${ }^{73-76} \mathrm{~T} 1 \mathrm{DM}$ accounts for approximately $5-10 \%$ of all cases of diabetes with the major susceptibility gene mapping to the HLA region of chromosome $6 .^{73,77}$ Type 2 diabetes mellitus (T2DM), or non-insulin-dependent diabetes mellitus (NIDDM), which is characterized by defects in hepatic glucose production, insulin action and insulin secretion, ${ }^{60,73}$ is the most common form of diabetes. T2DM accounts for approximately $90 \%$ of cases and affecting $10-20 \%$ of those over 45 years of age in many developed countries. ${ }^{60}$ It has been predicted that T2DM will affect 215 million people worldwide by $2010 .^{73,77}$

For both TIDM and T2DM, in most cases, the precise biochemical defects, genetic causes and other contributing factors of these diseases are not fully elucidated. ${ }^{73}$ However, it is becoming increasingly clear that members of the calpain family are involved in T2DM. ${ }^{73,77}$

In 1996, genome-wide scan studies for type 2 diabetes genes carried out in Mexican Americans localized a susceptibility gene, designated NIDDM1, at 2q37.3. ${ }^{60,78}$ Four years later, positional cloning studies revealed that NIDDM1 was a single gene, CAPN10, which encodes the intracellular cysteine protease, calpain $10 .^{77}$ This is the first diabetes gene identified through a genome scan. ${ }^{79}$ More recently attention has started to shift to focus on the functional biology of calpain-10 in pancreatic $\beta$-cells, skeletal muscle and adipocytes. ${ }^{79}$

A number of studies have suggested that calpains may be involved in T2DM-related pathways. ${ }^{77}$ Turner described the putative role(s) of calpain 10 in T2DM pathways in Figure $4 .^{79}$

Knowledge about the role of calpain 10 in diabetes will lead to improved diagnosis, treatment and prevention, and thereby could help to reverse the predicted rise in the prevalence of this disorder. ${ }^{60}$

\subsubsection{Cataract}

Cataract is a clouding of the eye's naturally clear lens. ${ }^{80}$ According to the World Health Organization, cataract is the leading cause of blindness in the world and affects nearly 20.5 million Americans age 40 and older. ${ }^{80,81}$ The exact cause of cataract is unclear, but it may be the result of a lifetime of exposure to ultraviolet radiation contained in sunlight, or may be related to other lifestyle factors such as cigarette smoking, diet, and alcohol consumption. ${ }^{81,82}$ To date, cataract removal is the most common treatment and more than a million such surgeries are performed each year ${ }^{80,82}$ 


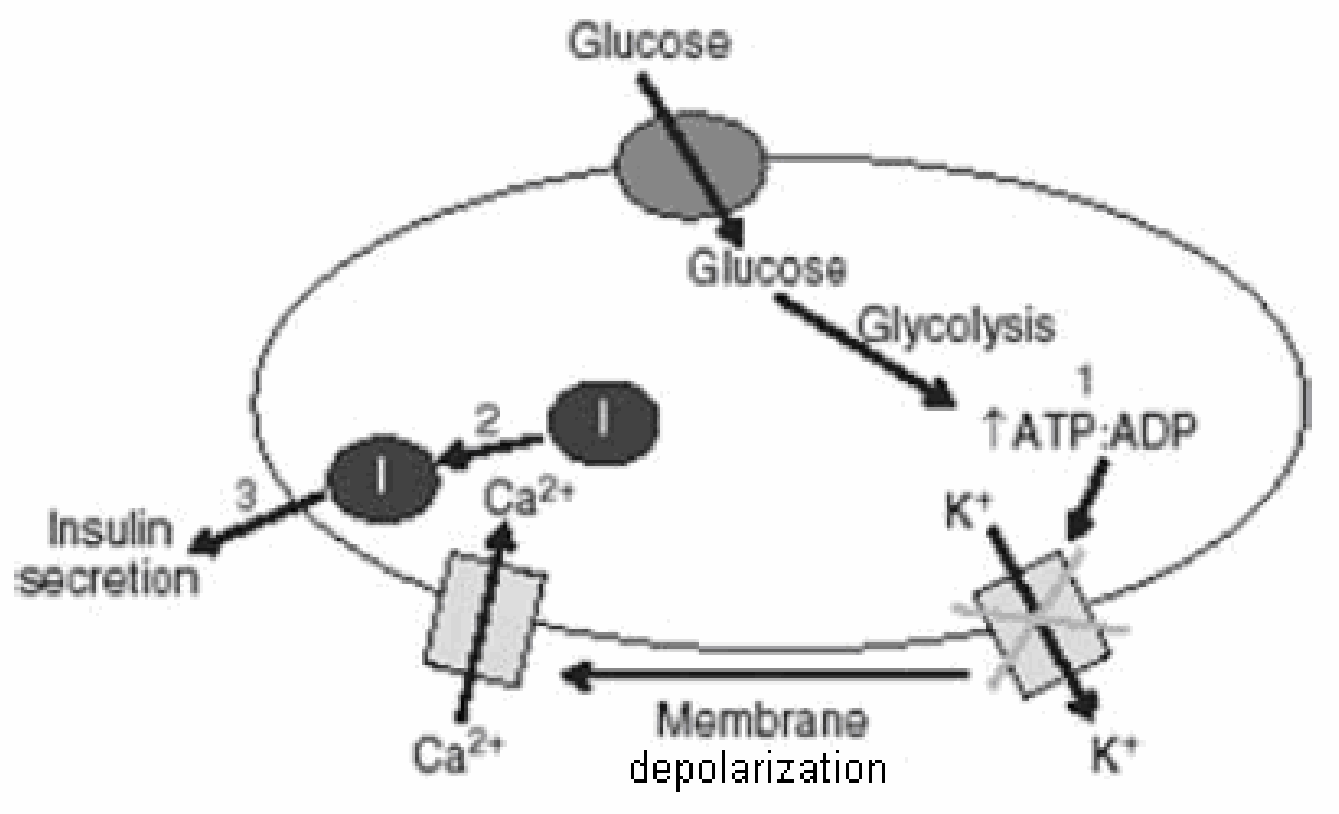

Figure 4. Proposed sites of action for calpain 10 in T2DM-related pathways. (1) The internalization of glucose leads to glycolysis and elevated ATP:ADP ratios through the action of mitochondria. This action is strongly diminished by calpain inhibition and calpain 10 is suggested to act as a regulator of mitochondrial fuel sensing. (2) The secretory stimulus is accompanied by cytoskeletal rearrangement, which leads to the transport of secretory granules containing insulin to active sites of exocytosis at the plasma membrane. In the case of adipocytes and skeletal muscle, this process proceeds via the translocation of vesicles containing GLUT4. This process is highly sensitive to calpin inhibition, either through the use of inhibitors or specific CAPN10 antisense nucleotides, and roles for calpain 10 and calpain 1 have been suggested. (3) Exocytosis is mediated by a SNARE family of proteins and a specific isoform of calpain 10 has been shown to associate with this family. Based on a number of evidence, calpain-10 has been proposed to be a pivotal $\mathrm{Ca} 2+$-sensor in exocytosis in $\beta$ cells.

Source: Harris, F.; Biswas, S.; Singh, J.; Dennison, S.; Phoenix, D. A. Calpains and their multiple roles in diabetes mellitus. Ann N Y Acad Sci 2006, 1084, 452-480. ${ }^{77}$ Adapted with permission from New York Academy of Sciences. 
However, surgery is not truly a cure for cataract ${ }^{83}$ and the cost of cataract surgery limits individuals in many parts of the world. So there is an urgent need for less expensive, nonsurgical approaches to cataract treatment. ${ }^{83}$ Now there are no therapeutic agents that can significantly prevent and treat cataract.

Biochemists are analyzing the formation of cataracts at a molecular level and five calpains are known to occur in the lens, including calpain $1,{ }^{29} \mathrm{Lp} 85,{ }^{84}$ calpain $2,{ }^{85}$ calpain $10^{86}$ and Lp82, a lens-specific splice variant of calpain $3 .{ }^{83}$ If calpain inhibitors can be used as anticataractogenic agents, they could be economical nonsurgical agents for cataract treatment. Some evidences suggest that calpain inhibitors would be beneficial in prevention and treatment of cataract. E64 showed some ability to reduce cataract in rodent models. ${ }^{87}$ E64d, derivative of E64, also prevented induced cataract in lens culture models. ${ }^{88,89}$ SJA6017, a high selective calpain inhibitor, was found to be able to prevent both $\mathrm{Ca}^{2+}$-induced nuclear opacity and crystallin proteolysis in a way that correlated with its ability to inhibit calpain $2 .^{10,11,83}$ More recently, SJA6017 has been shown to retard calpain-mediated cataractogenesis in porcine lenses ${ }^{90}$ and Lp82-mediated cataractogenesis in rodent lenses. ${ }^{83}$

\subsubsection{Cancer}

Association between abnormal calpain activity and tumorigenesis has been observed in many studies. Many gene products of oncogenes and tumor suppressor genes are substrates of calpain family enzymes, including c-fos, c-jun, p53, pp60src, the estrogen receptor and the adhesion molecule integrin. ${ }^{29}$ Activities of calpain were significantly higher in breast cancer tissues, compared with those of normal breast tissues $^{54}$, and were higher in the ER (estrogen receptor )-positive tumors than in ER-negative ones. ${ }^{25,29,91}$ Treatment of ER positive breast cancer cells with the synthetic peptide calpain inhibitor calpeptin can inhibit the growth of ER positive breast cancer cells but had no effect on growth of ER negative breast cancer cells. ${ }^{25,92}$ Calpain mediated cleavage of NF2 has been proposed as a mechanism that initiates tumourigenesis in a subset of schwannomas and meningiomas. ${ }^{93}$ Calpain also plays a positive regulatory role in melanogenesis through modulating the expression of tyrosinase. ${ }^{94}$ The endogenous calpain inhibitor was selectively cytotoxic to human tumor cells from lung, bladder, melanoma and chronic myeloid leukemia tissues, in a dose-dependent manner, but not cytotoxic to normal human, urothelial, fallopian tube, liver and resting white blood cells. ${ }^{95}$ The inhibitor was also tested in vivo on Wistar rats bearing Walker tumors. Treatment with 50 Units/100 g i.p. daily for 5 days caused $90 \%$ tumor regression and necrosis of metastatic foci in the liver and abdomen, without toxic side effects. ${ }^{95}$

At the molecular level, calpains 1, 2, 6 and 9 are thought to play a role in carcinogenesis. High expression levels of calpain 1 mRNA in tissue samples from human renal cell carcinoma correlated with metastasis to peripheral lymph nodes 
suggesting a role for calpain in both carcinogenesis and tumour progression. ${ }^{25,91,96}$ Calpain $1 \mathrm{mRNA}$ levels, were also found to be significantly increased in basal cell carcinoma (BCC) and squamous cell carcinoma (SCC) when compared with normal human skin. ${ }^{25,97}$ In chronic lymphocytic leukaemia (B-CLL) cells, calpain 1 activity was found to be significantly elevated when compared with non-malignant cells. ${ }^{25,98}$ Antisense-mediated suppression of calpain 2 gene expression reduced the invasion of human DU 145 prostate carcinoma cells both in vitro and in vivo. ${ }^{25,99}$ This study provides the first direct evidence that intervention against a single calpain isoform can influence tumor cell progression.

It has been suggested that calpain 6 may be associated with the development of uterine sarcoma and uterine malignant mullerian mixed tumors (MMMTs). Although the precise effect of increased expression of capn6 need further investigation, but calpain 6 may play a role as a novel tumor marker in those diseases. ${ }^{100}$

Expression of calpain 9 was downregulated in gastric cancer tissues and cell lines $^{25,52}$ and the depletion of calpain 9 by antisense RNA strategy resulted in cell transformation and tumourigenesis in murine NIH 3 T3 fibroblasts. ${ }^{25,53,54}$ These results suggest that calpain 9 might be a new type of tumor suppressor. Thus, identification of endogenous substrate(s) of calpain 9 might help to define underlying mechanisms in the development of gastric cancer.

\subsubsection{Alzheimer's Disease}

Alzheimer's disease (AD) is a brain disorder that seriously affects a person's ability to carry out daily activities, especially among older people. This disease usually begins after age 60, and risk goes up with age. About 5 percent of men and women ages 65 to 74 have $\mathrm{AD}$, and nearly half of those age 85 and older may have the disease. While younger people also may get $\mathrm{AD}$, it is much less common. As many as 4.5 million Americans suffer from AD, according to the data published by NIH in $2006 .{ }^{101}$ The etiology of $\mathrm{AD}$ is not fully clear. There probably are several factors that affect each person differently. Age is the most important known risk factor for AD. ${ }^{101}$

Molecular studies have shown that calpain is involved in AD. The two typical brain lesions in Alzheimer's disease are extracellular amyloid plaques, which are deposits of $\beta$-amyloid peptides, and intracellular neurofibrillar tangles, which are composed primarily of the hyperphosphorylated microtubule-associated tau protein. ${ }^{17,78} \beta$-Amyloid peptides, the major components of amyloid plaques in the brains of AD patients, ${ }^{102}$ can activate calpains, thereby mediating the cleavage of $\mathrm{PARP}^{103}$, an enzyme that is thought to contribute to the pathophysiology of AD by inducing neuronal apoptosis. ${ }^{102,104}$ Calpain is also thought to cleave $\mathrm{p} 35,{ }^{105}$ a regulator of cyclin-dependent kinase $5(\mathrm{cdk} 5)$ in the CNS, into two proteins, $\mathrm{p} 10$ and $\mathrm{p} 25$, and then the latter activates cdk5. ${ }^{104-106} \mathrm{p} 25 / \mathrm{cdk} 5$ can hyperphosphorylate tau, a substrate 
for CDK5. The hyperphosphorylated tau protein results in the formation of neurofibrillary tangles in AD's brains. ${ }^{78,104}$

Both m-calpain and $\mu$-calpain may be involved in Alzheimer's disease. ${ }^{107,108}$ Activated form of m-calpain is increased in the brains of AD patients. ${ }^{109,110} \mu$-Calpain is abnormally activated in $\mathrm{AD}$ brain ${ }^{108}$ and calpastatin, the endogenous inhibitor of calpains, is significantly decreased. ${ }^{109,111}$ These observations suggest the hypothesis that inhibition of calpain activity should prevent or retard the evolution of AD. ${ }^{109}$

\subsubsection{Ischemia}

Ischemia is an absolute or relative shortage of the blood supply to an organ. Calpain is suspected to play a major role in cerebral ischemia (stroke), traumatic brain injury (TBI), ${ }^{29,112}$ and ischemia in heart, ${ }^{27}$ kidney, ${ }^{113,114}$ and liver. ${ }^{115}$

Cerebral ischemia is an ischemic condition where the brain or parts of the brain do not receive enough blood flow to maintain normal neurological function. Traumatic brain injury (TBI), also called intracranial injury, or simply head injury, occurs when a sudden trauma causes brain damage. Cerebral ischemia and traumatic brain injury (TBI) represent the two most common and well-studied manifestations of in vivo excitotoxicity. In cerebral ischemia and traumatic brain injury, decreased blood flow in brain areas results in increases in presynaptic vesicular glutamate release and inhibition of glutamate re-uptake by adjacent astrocytes (Figure 5). ${ }^{29}$ The resultant excessive glutamate overactivates ionotropic glutamate receptors (NMDA, AMPA and kainate receptors), ${ }^{29}$ which allows $\mathrm{Na}^{+}$and $\mathrm{Ca}^{2+}$ influx, in the postsynaptic membrane. The elevated intracellular $\mathrm{Na}^{+}$level further triggers the opening of voltage-gated neuronal $\mathrm{Ca}^{2+}$ channels, and the resultant $\mathrm{Ca}^{2+}$ overload leads to activation of several calcium-dependent enzymes, including protein kinase $\mathrm{C}$ (PKC), calmodulin (CaM)-dependent NO synthase (NOS), protein kinase II (CaMPK-II), phospholipase A2 (PLA2), and especially calpain 1 and 2. ${ }^{29,87}$ A number of subcellular targets have been identified as substrates for calpain cleavage in the brain, including cytoskeletal proteins, membrane proteins and various other proteins, ${ }^{28}$ but the precise physiological role of calpain is not yet clearly understood. It is acknowledged that overactivated calpain could lead to uncontrolled degradation of cytoskeletal proteins, cytosolic and nuclear enzymes and, ultimately, neuronal death. ${ }^{29}$ Calpain 1 and 2 play a role in disabling the neurons in signal transduction, membrane and cytoskeleton integrity and nuclear function. ${ }^{29}$ Calpain inhibitor I and leupeptin can reduce neuronal damage in global ischaemia. ${ }^{116}$ Calpain inhibitor I and MDL 28170 can improve neuronal recovery from hypoxia. ${ }^{117,118}$ MDL 28170 also can reduce infarct size even 6 hours after the initiation of ischemia in a rat model of focal cerebral ischaemia, showing that calpain activation may be an obligatory, downstream event in the ischemic cell death cascade. ${ }^{119-121}$ Calpain inhibitors AK295 and AK275 provide significant neuroprotection in ischemia-induced proteolysis. ${ }^{122,123}$ All these 


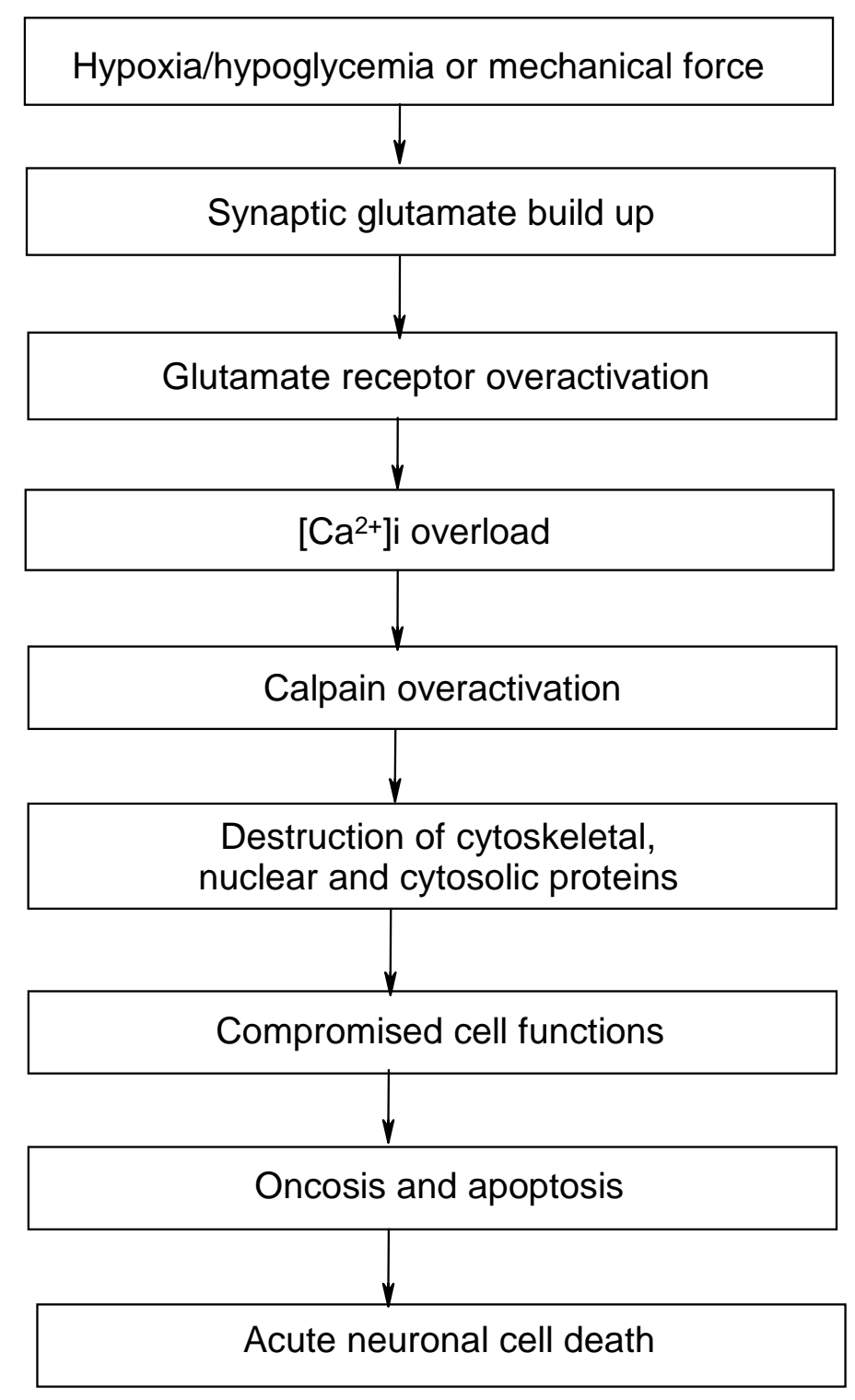

Figure 5. Calpain 1 and 2 in cerebral ischemia and traumatic brain injury.

Source: Huang, Y.; Wang, K. K. The calpain family and human disease. Trends Mol Med 2001, 7, 355-362. ${ }^{29}$ Modified with permission from Elsevier Ltd. 
cases indicate that inhibition of calpain may be a feasible therapy to maintain neuron functions. $^{121}$

Myocardial infarction is a medical condition that occurs when the blood supply to a part of the heart is interrupted. The resulting ischemia or oxygen shortage causes damage and potential death of heart tissue. Calpain is activated during myocardial ischaemia and calpain inhibitors showed beneficial effects. However, this area is not yet clearly understood. E64c was used as a potential protective agent in a dog model where acute myocardial infarction was induced by occlusion of the left anterior descending artery. The combination of E64c and reperfusion was found to significantly reduce infarct size. ${ }^{87}$

Ischemia-reperfusion ( $\mathrm{I} / \mathrm{R})$ injury involves a cascade of events that ultimately lead to cellular damage and organ dysfunction. It is one of the most important issues to be resolved in liver surgery. The activation of calpain appears essential in I/R-induced apoptosis, but cross-talk between calpain and the caspase systems in apoptosis remains unclear at present. In addition to calpain and caspases, other proteinases such as nuclear serine protease and cathepsin B may also contribute to the apoptosis of hepatocytes. In a rat model of hepatic I/R injury, the calpain inhibitor, Cbz-Val-Phe methyl ester, inhibited cell necrosis and apoptosis of the sinusoidal endothelial cells and hepatocytes, suggesting that calpain may play a role upstream of caspases. $^{124}$

\subsection{Calpain Inhibitors}

Crystal structures of calpain with inhibitor proved that calpain inhibitors can target against the active catalytic site or interact with other allosteric sites of calpain that are important in catalytic activation. ${ }^{13,125}$ Based on different binding position, calpain inhibitors can be divided into active site directed calpain inhibitors and allosteric inhibitors.

\subsubsection{Active Site Directed Calpain Inhibitors}

Active site directed calpain inhibitors usually are the peptidomimetic of calpain substrate. They are composed of an address region for enzyme recognition and a "warhead" for interaction with the active site cysteine residue in enzyme (Figure 6). The warhead is an electrophilic group which can react either reversibly or irreversibly with the thiol in the cysteine residue of calpain. According to the different interaction with the cysteine residue of calpain active site, active site directed calpain inhibitors can be sub-divided into irreversible and reversible calpain inhibitors. 




Inhibitor: MDL-28170<smiles>[R6][C@@H](N)C(=O)N[C@@H](P)C(=O)S([Y9])([3H])N[C@@H](P)C(=O)O</smiles>

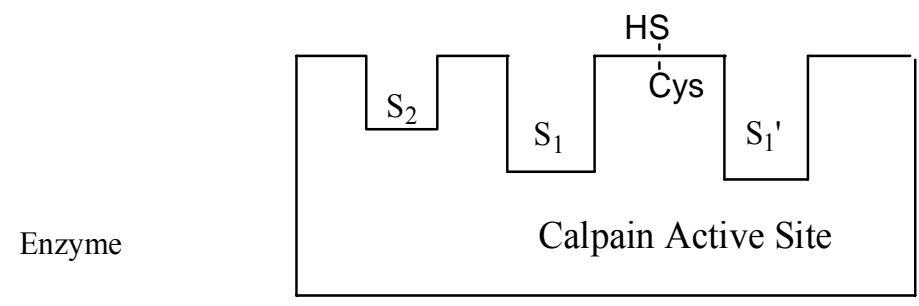<smiles>CCCC(NC(=O)C(P)NP)C(=O)NCP</smiles>

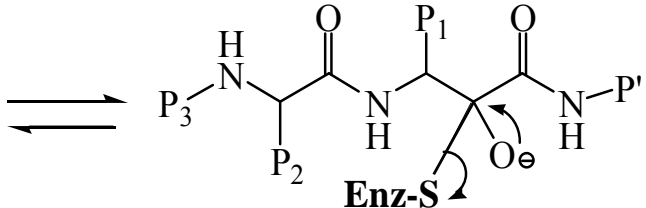

Figure 6. Relationship among calpain, substrate and inhibitors. Scissile bond refers to the bond in the substrate that is hydrolyzed by the enzyme. The address region of calpain inhibitors is region for enzyme recognition. $\mathrm{P}_{1}, \mathrm{P}_{2}$ and $\mathrm{P}_{3}$ refer to the side chain of different amino acid from the scissile bond to the amino terminal. P' refers to the side chain of different amino acid from the scissile bond to the acid terminal. $\mathrm{S}_{1}$, $S_{2}$ and $S_{2}$ refer to the binding positions of enzyme in the corresponding to $P_{1}, P_{2}$ and $\mathrm{P}$ ' positions of the peptide substrate. 


\subsubsection{Irreversible Calpain Inhibitors}

Peptidyl epoxysuccinate calpain inhibitors are a well-studied group of irreversible calpain inhibitors. Epoxysuccinyl derivate E-64 (Figure 7), isolated from Aspergillus japonicus, ${ }^{25}$ is used in many publications. It is selective for cysteine proteases ${ }^{13}$ but not cell permeable because of the presence of charged carboxylate and guanidinium groups. ${ }^{25}$ Modification of E64 by esterification of the carboxyl group and modification of the guanidinium group to a benzyloxycarbonyl group resulted in a cell permeable compound E64d (Figure 7), which has an N-terminal capping with a benzyloxycarbonyl group, and can be converted in vivo to its active form E64c (Figure 7) by hydrolysis of the ester. ${ }^{25,126}$ Intraperitoneal injection of E64 prior to selenite induced cataract formation in mice can reduce both the frequency and severity of cataract formation. ${ }^{25,127}$ Administration of E64d in vivo can reduce muscle degeneration and muscular dystrophy in dystrophic mice and hamster models. ${ }^{25}$ Also a significant neuroprotection by E64d following spinal cord injury in rats has been reported. ${ }^{25,128}$ E64c was reported to significantly reduce ischaemic injury and infarct size in a canine model of acute myocardial infarction. ${ }^{25,129}$ In cultured lenses, E64, E64c and E64d can reduce nuclear opacity by calcium ionophore A23187 in a concentration-dependent manner, and E64d ,was the most effective. ${ }^{89}$

Besides epoxide group, reported warhead replacements of irreversible calpain inhibitors are ketomethylenes, methylsulfonium salts, vinyl sulfones, and disulfide linkages (Figure 8). Recently published potent selective compounds don't show these functional groups and focused on reversible calpain inhibitors. Irreversible calpain inhibitors have high activated electrophilic groups which is difficult to differentiate thiol in cysteine protease with other nucleophilic groups in protease (for example, hydroxyl group in serine protease) and cause unexpected adverse effects.

\subsubsection{Reversible Calpain Inhibitors}

Reversible calpain inhibitors are derived from natural sources, such as calpastatin and leupeptin, and chemical synthesis sources. Functional groups have been reported to be warheads are aldehydes, $\alpha$ - ketocarbonyls, and $\alpha$-keto heterocycles in reversible calpain inhibitors. The $\alpha$-ketocarbonyl compounds include $\alpha$-ketoacids, $\alpha$-ketoamides, ${ }^{130} \alpha$-ketoesters, ${ }^{130} \alpha$-diketones, and $\alpha$-ketophosphorous ${ }^{131}$ (Figure 8). Because aldehyde is more electrophilicity, less electrophilic $\alpha$-keto carbonyl compounds are more possible to be selective to calpain over other cystein protease. So recent published potent active site directed reversible calpain inhibitors are focused on peptidyl aldehydes and peptidyl $\alpha$-ketoamides. ${ }^{25}$ Besides, replacing the metabolically labile aldehyde moiety with cyclic hemiacetal, for example SNJ-1715 (Figure 7), could increase potency, aqueous solubility, excellent oral bioavailability, and prolonged plasma half-life in rat model. ${ }^{132}$ 




b. Reversible calpain inhibitors

c. Non-peptide inhibitors
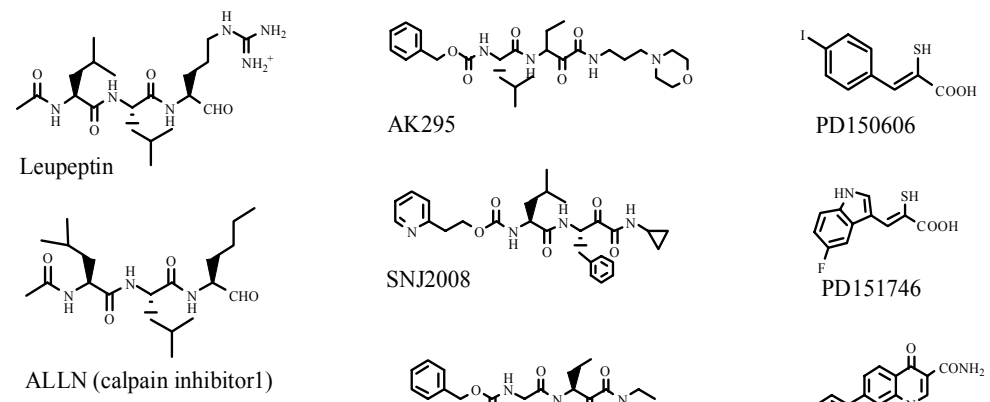

SNJ2008

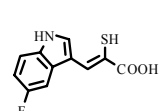

PD151746
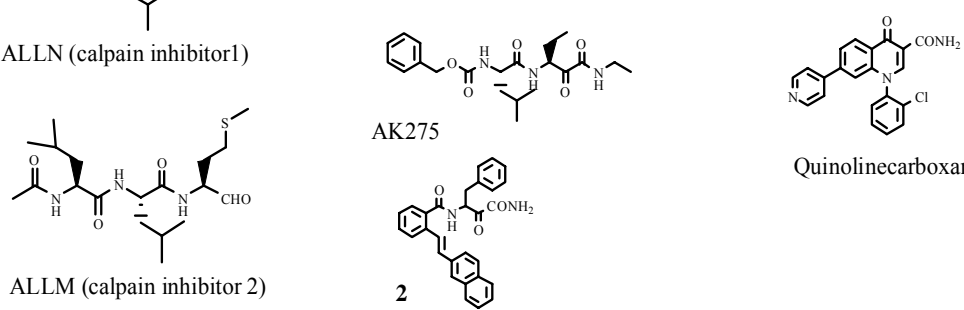

Quinolinecarboxamide
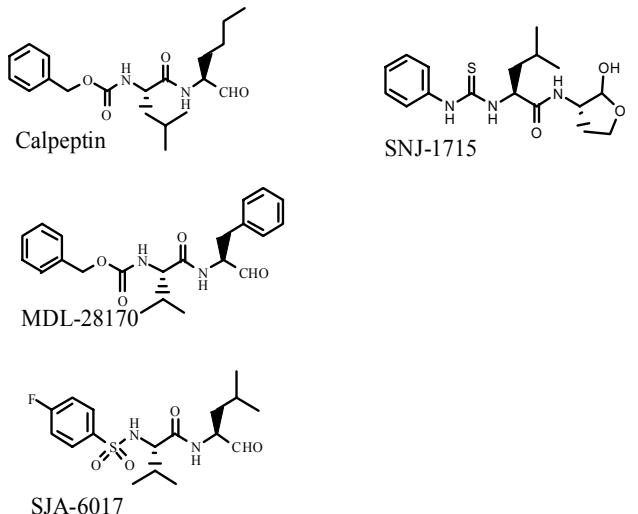

SNJ-1715

SJA-6017

Figure 7. Typital calpain inhibitors. 
a. Warheads of irreversible inhibitors<smiles>[Te]C1OC1[123I]</smiles>

epoxide<smiles>[X]CC(=O)CCC</smiles>

ketomethylene<smiles>C[S+](C)CC(=O)C[S+](C)C</smiles>

methylsulfonium salt<smiles>[Z]C/C=C/S(=O)(=O)O</smiles>

vinyl sulfone
\{-S-S- \{

disulfide linkage

b. Warheads of reversible inhibitors<smiles>CCC=O</smiles>

aldehyde<smiles>CCCC(=O)C(=O)O</smiles>

$\alpha$-ketoacid<smiles>CC(=O)C(N)=O</smiles>

$\alpha$-ketoamide<smiles>[R]OC(=O)C(=O)O</smiles>

$\alpha$-ketoester<smiles>[R]C(=O)C([Y])=O</smiles>

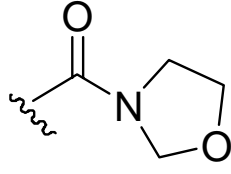<smiles>[R]P([R])(=O)C(=O)O</smiles>

$\alpha$-diketones

$\alpha$-ketoheterocycle $\alpha$-ketophosphorous

Figure 8. Functional groups of warheads in calpain inhibitors. $\mathrm{R}=$ substituted group; $\mathrm{X}=$ halogen.

Source: Donkor, I. O. A survey of calpain inhibitors. Curr Med Chem 2000, 7, 1171-1188. ${ }^{156}$ Modified with permission from Bentham Science Publishers Ltd. 
Calpastatin is an endogenous calpain multiheaded ${ }^{133}$ inhibitor that specifically inhibits both major isoforms of calpain, $\mathrm{m}$ - and $\mu$-calpains. ${ }^{13,134,135}$ It binds and inhibits calpain when calcium levels are high, and is released when calcium levels fall. ${ }^{135}$ To date calpastatin is the only inhibitor that is completely specific for calpain. ${ }^{135}$ Calpastatin does not inhibit cysteine proteases, such as papain, cathepsin B, bromelin, or ficin, and other proteases such as trypsin, chymotrypsin, plasmin, thrombin, pepsin, cathepsin $\mathrm{D}$, or thermolysin. ${ }^{17,136}$ Calpastatin is well conserved with greater than $70 \%$ identity across mammalian species. It is encoded by a single gene that has no obvious homologues. ${ }^{135}$ The structure of calpastatin polypeptide (Figure 9) contains five domains, four homologous inhibitory domains of approximately 140 amino acids each and a unique $\mathrm{N}$-terminal domain, termed domain L, with no inhibitory effect. ${ }^{13,133,135}$ Each inhibitory domain contains three well-conserved subdomains, A, B and C. ${ }^{133}$ Subdomains A and C of calpastatin interact at $\mathrm{nM}$ affinity with domain IV and domain VI of calpain, respectively. ${ }^{135,137}$ While subdomain B interacts weakly with calpain in the absence of its flanking A and $\mathrm{C}$ regions ${ }^{135}$ and is thought to bind to the catalytic site of domain II or domain III of calpain. ${ }^{138}$ Each inhibitory domain is capable of inhibiting one calpain molecule, ${ }^{133}$ so it is considered as calpain multiheaded inhibitor.

Plants are rich sources of calpain inhibitors. Peptidyl aldehyde calpain inhibitors, including leupeptin, ${ }^{139}$ strepin P-1, ${ }^{140}$ and staccopins P-1 and P-2, ${ }^{141}$ can inactivate calpain by interacting reversibly with the active site thiol of the enzyme, but the problems are this inactivation is not selective to calpain and poor cellular permeability. ${ }^{13}$ In addition, Hiwasa and colleagues ${ }^{13,142}$ isolated damnacanthal, an anthraquinone compound, from the root of Morinda critrifolia can also effectively inhibit calpain. Some other calpain inhibitors isolated from plants were well summaried by Donkor. ${ }^{13}$

Although many potent calpain inhibitors have been isolated from natural sources, the problems of isolating compounds are selectivity over other cysteine proteases, cell permeability, and even metabolic stablility. So the modification of compounds was focused on improving these disadvantages.

Peptidyl aldehydes (Figure 7) are the largest group of calpain inhibitors. They can form a hemithioacetal intermediate by reacting with the active site thiol of the calpain catalytic cysteine. The prototypical compound ${ }^{25}$ of this inhibitor class was leupeptin (Figure 7), which was isolated from streptomyces and can enhance neuronal survival in gerbils subjected to transient ischaemic injury ${ }^{25,121}$ and reduce experimental spinal cord injury in vivo. ${ }^{25,143}$ Leupeptin is a potent inhibitor of both $\mu$-calpain and m-calpain, but also of plasmin, trypsin, papain, and cathepsin $\mathrm{B} .{ }^{13}$ The other problem is that it is not cell permeable because of the positively charged guanidinium group.

Modification of leupeptin produced a series of representative peptide aldehydes (Figure 7) which have greater cell permeability. Tripeptidyl aldehydes, ALLN (calpain 


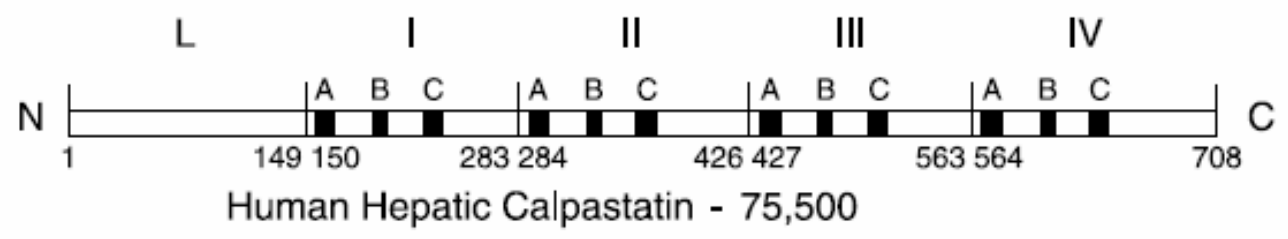

Figure 9. Domain structure of human hepatic calpastatin. $\mathrm{N}=$ amino terminal domain; $\mathrm{C}=$ carboxy terminal domain; I, II, III, IV and L = domain; A,B,C = subdomain.

Source: Wendt, A.; Thompson, V. F.; Goll, D. E. Interaction of calpastatin with calpain: a review. Biol Chem 2004, 385, 465-472. ${ }^{133}$ Adapted with the permission from Walter de Gruyter, Inc. 
inhibitor 1) and ALLM (calpain inhibitor 2), ${ }^{13,144}$ have been proven effective as calpain inhibitors. ALLN can reduce infarct size and neuronal damage in a rat model of focal ischaemia $^{25,116}$ and attenuate the systemic inflammatory response and multiple organ failure mediated by endotoxin in the rat. ${ }^{25,145}$ ALLN and calpeptin have both been shown to reduce vessel restenosis following experimental transluminal angioplasty dilation of an atherosclerotic femoral artery in rabbits. ${ }^{25,146}$ However, ALLN and ALLM are not specific for calpain. ALLN is a good inhibitor for cathepsin L ( $K i=0.5$ $\mathrm{nM})$ and ALLM inhibits cathepsin $\mathrm{B}(\mathrm{Ki}=100 \mathrm{nM}){ }^{13}$

Calpeptin, MDL-28170 and SJA-6017 (Figure 7) are referred to be N-protected dipeptidyl aldehydes. Calpeptin is cell permeable and inhibits human platelet calpain 2 with an $\mathrm{IC}_{50}$ of $40 \mathrm{nM} .^{13}$ MDL-28170, which is also cell permeable, ${ }^{8,13}$ can reduce neuronal damage in a rat model of cerebral ischemia ${ }^{25,120}$ and reduce neuronal loss and improved locomotor functions in a mouse model of Parkinson's disease. ${ }^{25,147}$ Besides, pre-injury administration of MDL-28170 in a rat model of diffuse brain injury can reduce neuronal injury. Post-injury administration of MDL-28170 by intraspinal microinjection in rats can effectively blocked elevation of calpain activity and attenuate axonal damage. ${ }^{25}$ Post-injury administration of SJA-6017 improved neuronal functional outcome ${ }^{12,25}$ in a mouse model of diffuse head injury. In addition, SJA-6017 showed neuroprotective efficacy via intravenous administration ${ }^{9}$ in the rat retinal ischemia model. But its oral bioavailability was low due to the metabolic lability and low water-solubility. ${ }^{9}$

Peptidyl $\alpha$-ketoamides (Figure 7) were found on development of selective calpain inhibitors with other peptidyl $\alpha$-ketone compounds. The $\alpha$-ketone compounds were supposed to reversibly form an enzyme-bound intermediate that results from the nucleophilic addition of the catalytic thiol of calpain to the electrophilic ketone of the inhibitor. ${ }^{148}$ Because electrophilicity of $\alpha$-ketone compounds is less than aldehyde, it is thought that $\alpha$-ketone compounds may be more selective than aldehyde compounds. In general $\alpha$-ketoamides were more effective toward calpain 1 and 2 than $\alpha$-ketoesters, ${ }^{14}$ so most recently published papers were focused on $\alpha$-ketoamides

The early lead inhibitors, mostly aldehyde inhibitors, were hydrophobic and therefore poorly soluble in aqueous solutions. ${ }^{148} \alpha$-ketoamides were developed to improve membrane permeability and the metabolic stability of aldehydes in vivo. ${ }^{14,25}$ For example, AK275 (Figure 7) exhibits calpain inhibitory activity (Ki=109nM for porcine calpain I) and improved cell permeability. ${ }^{148}$ AK295 (Figure 7), which has a morpholinopropyl group replacing the ethyl group of AK275, significantly improved solubility in aqueous solutions. ${ }^{148,149}$ Both AK295 ${ }^{15}$ and AK275 ${ }^{150}$ provide significant neuroprotection against ischemic brain damage. Some other novel $\alpha$-ketoamide derivatives that exhibit calpain inhibitory activity and can suppress neuronal damage in models of ischaemic and excitotoxic damage have been reported. ${ }^{25,149,151,152}$ 
In order to increase the water solubility, structure modification was going on $\mathrm{P}_{3}$ position. SNJ-2008 (Figure 7), which has a pyridine group on the $\mathrm{P}_{3}$ position, exhibited metabolic stability (about a 12-fold higher retinal AUC than SJA-6017), higher water-solubility, and would show retinal efficacy at a lower dose than aldehyde lead SJA-6017. ${ }^{9}$

An important inhibitor, compound 2 (Figure 7), was reported on 2002, ${ }^{153}$ This naphthalene substituted compound has a Ki of $6 \mathrm{nM}$ to human calpain ${ }^{153}$ and represents one of the most potent calpain inhibitors, which are not derived from aldehydes. It also showed a moderate selectivity to cathepsin B (15-fold) and excellent selectivity to cathepsin L (1000-fold). ${ }^{153}$ Compound 2 did not block non-cysteine proteases even up to higher $\mathrm{mM}$ concentrations. ${ }^{153}$

\subsubsection{Allosteric Calpain Inhibitors}

Researchers have recently begun to be interested in nonpeptide calpain inhibitors (Figure 7). The reason that non-peptide inhibitors are attractive is that they are not targeted against the active catalytic site but may interact with other allosteric sites of calpain that are important in catalytic activation. ${ }^{25}$ This makes them selective calpain inhibitors over other cysteine proteases, even among the calpain subtypes.

PD150606 and PD151746 ( $\mathrm{Ki}=0.21$ and $0.26 \mu \mathrm{M}$ for $\mu$-calpain, respectively, Figure 7) are two $\alpha$-mercaptoacrylic acid derivatives that are potent, selective and cell permeable inhibitors of calpain. X-ray crystal studies revealed that PD150606 inhibit calpain by binding to a hydrophobic pocket on domain VI of calpain small subunit. ${ }^{154}$ PD151746 even showed approximately 20 -fold selectivity for $\mu$-calpain relative to m-calpain. ${ }^{25,155}$ Carboximide derivatives such as quinolinecarboximides $(\mathrm{Ki}=0.5 \mu \mathrm{M}$, Figure 7) showed significant selectivity and exhibited almost 50-fold more inhibitory activity against $\mu$-calpain relative to both cathepsin B and cathepsin L, members of cysteine proteases. ${ }^{13,25}$ The $\alpha$-mercaptoacrylic acids derivatives are cell-permeable and extremely selective for calpain (approximately 600-fold more selective for calpain relative to cathepsin B). ${ }^{25}$ Some other nonpeptide compounds were well summaried by Donkor in $2000 .^{13}$

\subsubsection{SAR of Current Calpain Inhibitors}

The binding mechanism for most of the nonpeptide calpain inhibitors has yet to be elucidated. They may interact with calpain at an allosteric site on the enzyme. ${ }^{25}$ Calpain inhibitors targeted against the active catalytic site of calpain usually consist of an address region for enzyme recognition and an electrophilic group (warhead) that can react with the active site cysteine of the enzyme (Figure 6). In reversible inhibitors, the electrophilic group (usually aldehyde or $\alpha$-keto carbonyl) form reaction 
intermediates (hemithioacetal or hemithioketal) with the active site thiolate of the enzyme, which mimics the mechanism of hydrolysis reaction catalyzed by cysteine proteases.${ }^{156}$ All the requirements of SAR are summaried in Figure 10.

\subsubsection{1 $P_{1}$ Position}

The $\mathrm{S}_{1}$ subsite of calpain can tolerate a wide variety of amino acids at the $\mathrm{P}_{1}$ position of inhibitors. ${ }^{13}$ The incorporation of aliphatic (Val, Nle, Leu, Abu, Cha, and Met) and aromatic (Phe, $\operatorname{Tyr}(\mathrm{O}-\mathrm{Benzy}))$ at the $\mathrm{P}_{1}$ position resulted in compounds with good or moderate calpain I inhibitory activity. ${ }^{157}$ Hydrophobic groups will enhance potency while incorporation of amino acids which are capable of hydrogen bonding does not increase potency (such as Ser, Thr, Gln and Tyr) ${ }^{157}$ and is detrimental to binding. ${ }^{13}$ Aromatic amino acids are less potent than aliphatic amino acids. ${ }^{157}$ No substituted group, Gly, is detrimental to activity, compared with Ala. ${ }^{157}$

\subsubsection{2 $\mathrm{P}_{2}$ Position}

It was generally thought that the $\mathrm{P}_{2}$ substitute must be either L-valine or L-leucine in order to have potent calpain inhibitory activity. ${ }^{13} \mathrm{P}_{2}$ prefer aliphatic side chain and amino acids at $\mathrm{P}_{2}$ which are capable of hydrogen bonding does not increase potency. ${ }^{157}$ Besides acidic or basic amino acids are not beneficial at $\mathrm{P}_{2} \cdot{ }^{157} \mathrm{~A}$ recent study showed that peptides with $\mathrm{D}$-amino acids at $\mathrm{P}_{2}$ postion were also potent calpain inhibitors. ${ }^{158,159}$ Donkor et al. replaced $\mathrm{P}_{2}$ chiral carbon with nitrogen to make it urea-based peptidomimetic calpain inhibitors. The compounds mirrored the general SAR of peptidyl aldehyde calpain inhibitors and displayed greater selectivity for $\mu$-calpain over cathepsin B. ${ }^{3}$

\subsubsection{N-Terminal Capping}

The N-terminal capping of the calpain inhibitors is one of the most interested regions in the development of selective and cellular permeability calpain inhibitors. It can tolerate bulky groups and provide an additional recognition element for binding to the $\mathrm{S}_{3}$ and $\mathrm{S}_{4}$ subsites of calpain. Polar pyridineethanol ${ }^{9}$ group was used to increase potency and some of pyridineethanol compounds showed a good oral bioavailability. Groups used as N-terminal capping agents ${ }^{13}$ are benzyloxycarbonyl, acetyl, aryl (or alkyl) sulfonyl, alkanoyl, substituted benzoyl, naphthoyl, thionaphthalene, ${ }^{13,160}$ fluorine, xanthines ${ }^{13,158}$ and pyridineethanol, Chromone, ${ }^{7}$ 3,4-dihydro-1,2-benzothiazine 1,1-dioxide ring (Figure 11). ${ }^{161,162}$ 


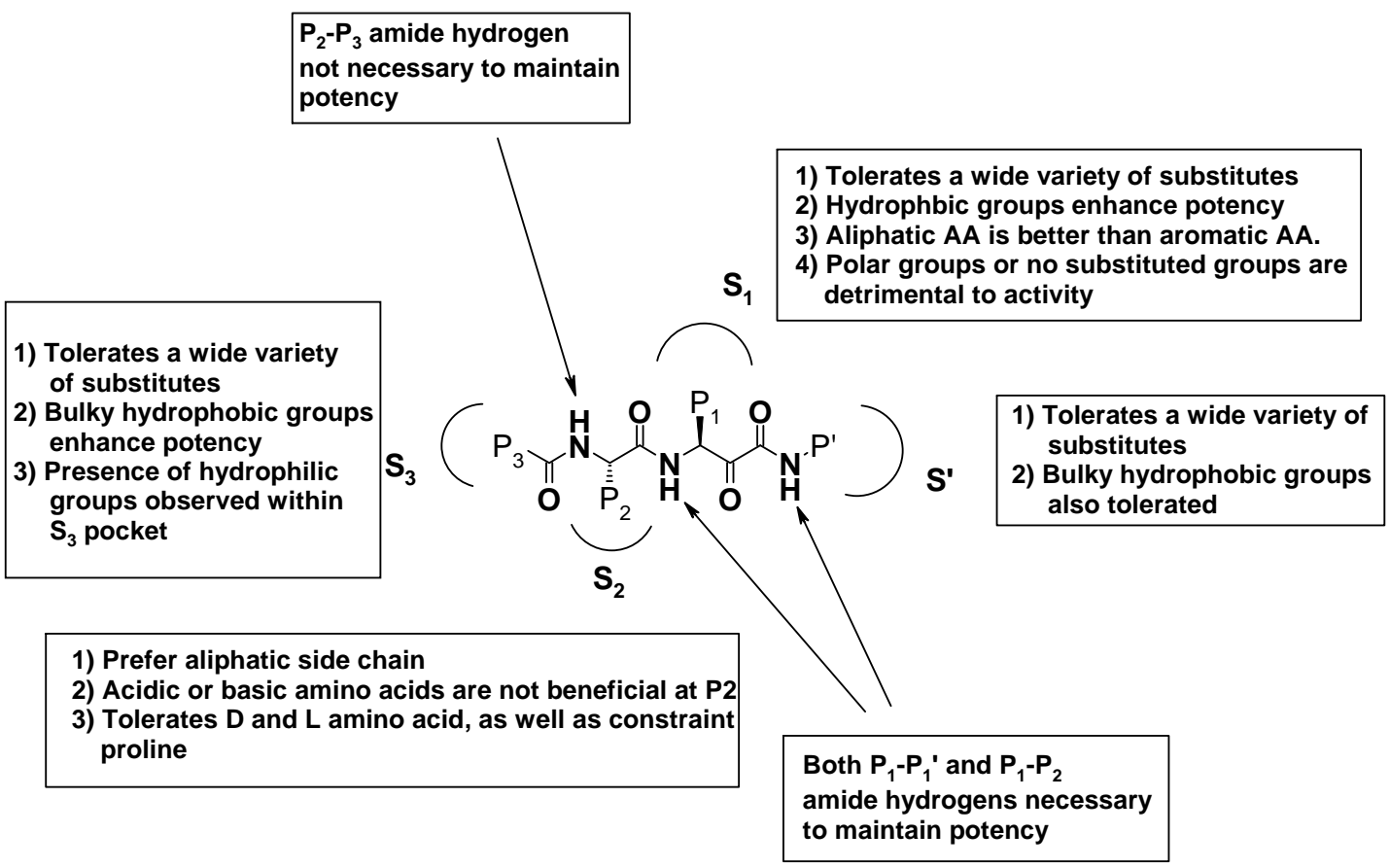

Figure 10. SAR of calpain inhibitors. 
<smiles>CC(=O)OCc1ccccc1</smiles>

benzyloxycarbonyl (Cbz)<smiles>CC(=O)c1cccc2ccccc12</smiles><smiles>CC(=O)c1ccc2ccccc2c1</smiles>

naphthyl groups<smiles>[R]#CCc1cc(=O)c2ccccc2o1</smiles>

Chromone

1,2-benzothiazine 1,1-dioxide<smiles>CC(=O)C1c2ccccc2-c2ccccc21</smiles><smiles>CC(=O)C1c2ccccc2Oc2ccccc21</smiles>

fluorene

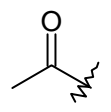

acetyl<smiles>[R]S([R])(=O)=O</smiles>

sulfonyl groups<smiles>C[As](O)c1ccc2ccccc2c1</smiles>

thionaphthalene<smiles>COCCc1ccccn1</smiles>

pyridineethanol,

Figure 11. Amino terminal capping groups. 


\subsubsection{P'Position}

Li and colleagues ${ }^{14}$ demonstrated that the $\mathrm{S}_{1}$ ' pocket can tolerate a wide variety of substitutes including large hydrophobic groups at the $\mathrm{P}_{1}$ ' position. Polar morpholinopropyl group was also successfully introduced to increase the solubility of the compound without affecting activity.

\subsubsection{Amide Hydrogen}

Replacement of $\mathrm{P}_{1}-\mathrm{P}_{2}$ amide with ketomethylene isostere could decrease calpain inhibitory potency by 250 fold (Figure 12). This suggested that the hydrogen bonding between calpain and the $\mathrm{P}_{1}-\mathrm{P}_{2}$ amide hydrogen of the inhibitor is important for calpain inhibitory potency. ${ }^{163}$ Donkor et al. showed that Gly271 is the active residue of calpain that makes the critical hydrogen bond between the calpain 1 and the $\mathrm{P}_{1}-\mathrm{P}_{2}$ amide hydrogen. ${ }^{164}$ Donkor et al. also proved that $\mathrm{P}_{1}{ }^{\prime}-\mathrm{P}_{2}{ }^{\prime}$ amide hydrogen is necessary to maintain potency, without it the activity of inhibitor could decrease by 380 fold (Figure 12). ${ }^{164}$ Besides, Chaterjee et al. ${ }^{160}$ and Donkor ${ }^{3}$ proved that the $\mathrm{P}_{2}-\mathrm{P}_{3}$ amide hydrogen of a calpain inhibitor is not a strict requirement for calpain inhibition. 

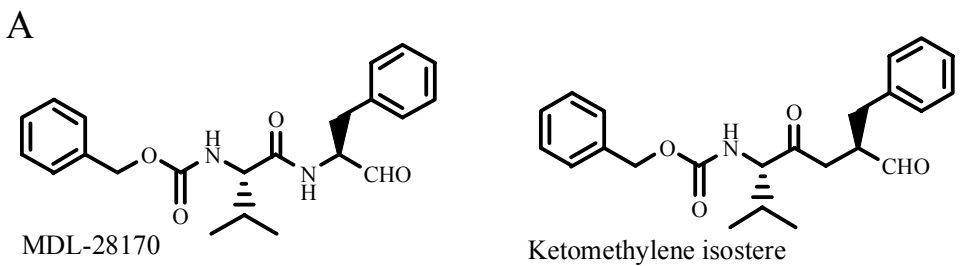

250 fold less potent than MDL-28170
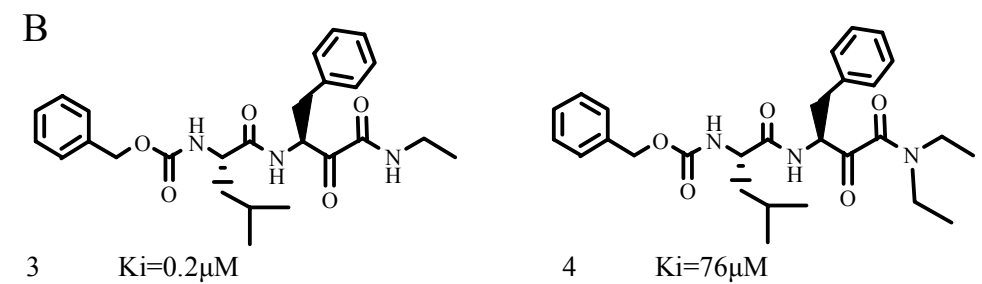

380 fold less potent than 3

Figure 12. Importance of amide hydrogen. 


\section{CHAPTER 2. EXPLORATION OF DIAZOSULFONAMIDE DERIVATIVES AS CALPAIN INHIBITORS}

\subsection{Structural Requirements Study of Diazosulfonamide 1}

\subsubsection{Objective}

Virtual screening of the NCI compound library led to the identification of diazosulfonamide 1 (Figure 1) as a new nonpeptide competitive inhibitor of calpain 1 (Donkor et al. Unpublished data). Analogs of diazosulfonamide 1 (Figure 13) were synthesized to explore the structural requirements of $\mathbf{1}$ that are important for calpain inhibition as a prelude to the synthesis of novel sulfonamide-based peptidomimetic calpain inhibitors.

\subsubsection{Chemistry}

The synthesis of compounds $\mathbf{1}$ and 5-7 from the corresponding sulfanilamide (8) and sulfathiazole (9) is outlined in Scheme 1. The sulfonamides were diazotized using $\mathrm{NaNO}_{2} / \mathrm{HCl}$ to obtain the corresponding diazonium salts, which were treated with salicylic acid or 3-hydroxybenzoic acid under basic condition $(20 \% \mathrm{NaOH})$ to afford the target compounds after purification by flash chromatography.

\subsubsection{Results and Discussion}

Diazosulfonamide 1 was identified by Donkor et al. (unpublished data) to be a nonpeptide competitive inhibitor of calpain 1. Figure 14 shows the interaction of the compound with active site residues of calpain. The carboxylic acid group of $\mathbf{1}$ formed a hydrogen bond with the $\mathrm{NH}$ of the imidazole side chain of His 272 while the $\mathrm{OH}$ of Ser251 formed hydrogen bonds with the nitrogen of the thiazole ring and one of the sulfamoyl oxygen atoms of compound 1. A fourth hydrogen bond was formed between the other sulfamoyl oxygen and Thr210.

Analogues of 1 (compounds 5-7 in Figure 13) were synthesized and studied as inhibitors of calpain with the goal of exploring the structural requirements of $\mathbf{1}$ that are important for inhibition of the enzyme as a prelude to the synthesis of novel sulfonamide-based peptidomimetic calpain inhibitors. The compounds were tested against porcine erythrocyte calpain 1 using Suc-Leu-Tyr-AMC as the substrate by following the procedure of Donkor et al. ${ }^{165}$ The calpain inhibitory activity of the compounds is shown in Figure 13. Compound 5 was over 60 -fold less potent than $\mathbf{1}$ suggesting that the hydrogen bonding interaction between the carboxylic acid group 

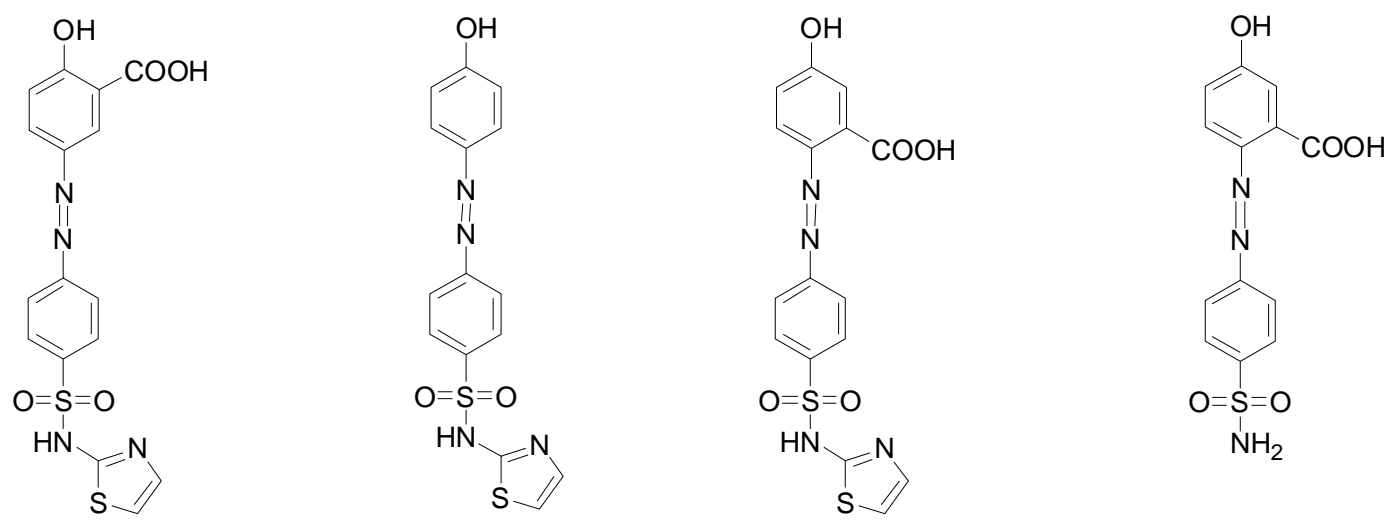

$1, K_{\mathrm{i}}=1.0 \pm 0.02 \mathrm{uM}$

5, $K_{\mathrm{i}}=63.2 \mathrm{uM}$

6, $K_{\mathrm{i}}=9.89 \pm 2.62 \mathrm{uM}$

$7, K_{\mathrm{i}}=55.0 \pm 2.53 \mathrm{uM}$

Figure 13. Structure and calpain inhibitory activity of compound $\mathbf{1}$ and its analogues. $K i=$ Inhibitory activity of the compounds versus porcine erythrocyte calpain 1 .

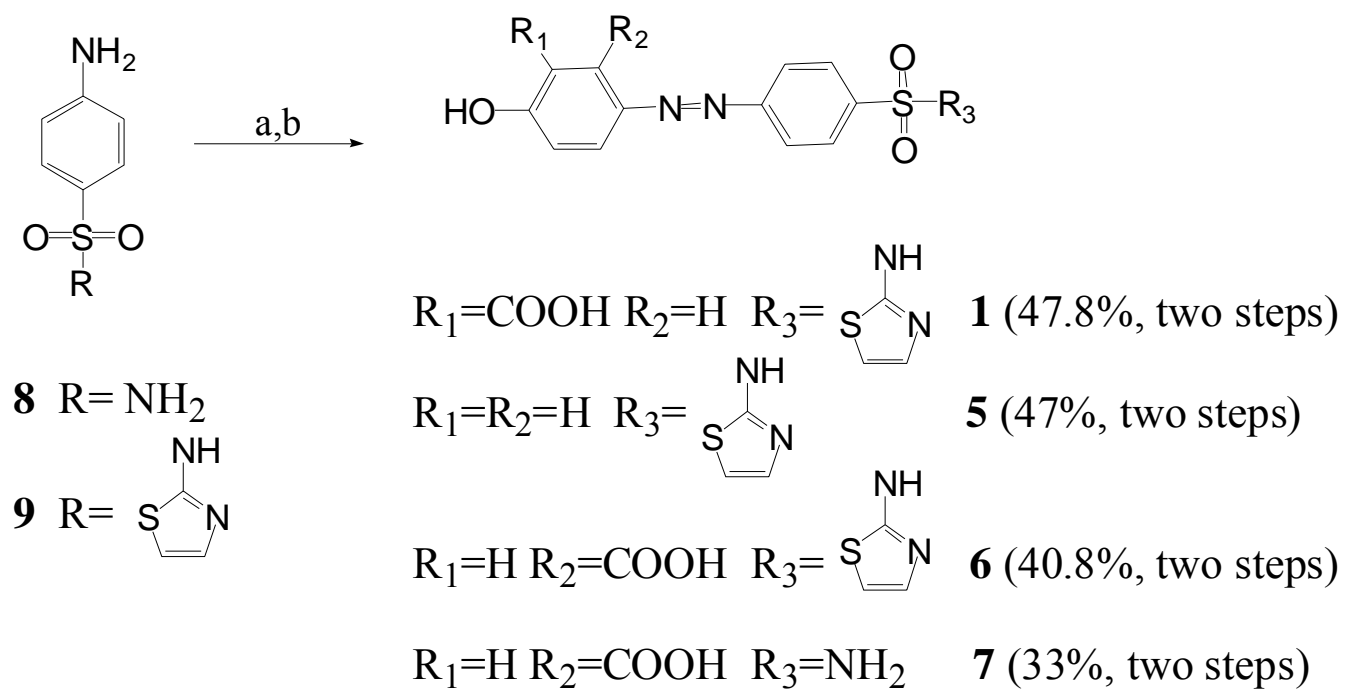

Scheme 1. Synthesis of compounds 1 and 5-7.

Reagents: (a) $\mathrm{HCl}, \mathrm{NaNO}_{2}$; (b) $20 \% \mathrm{NaOH}$. 


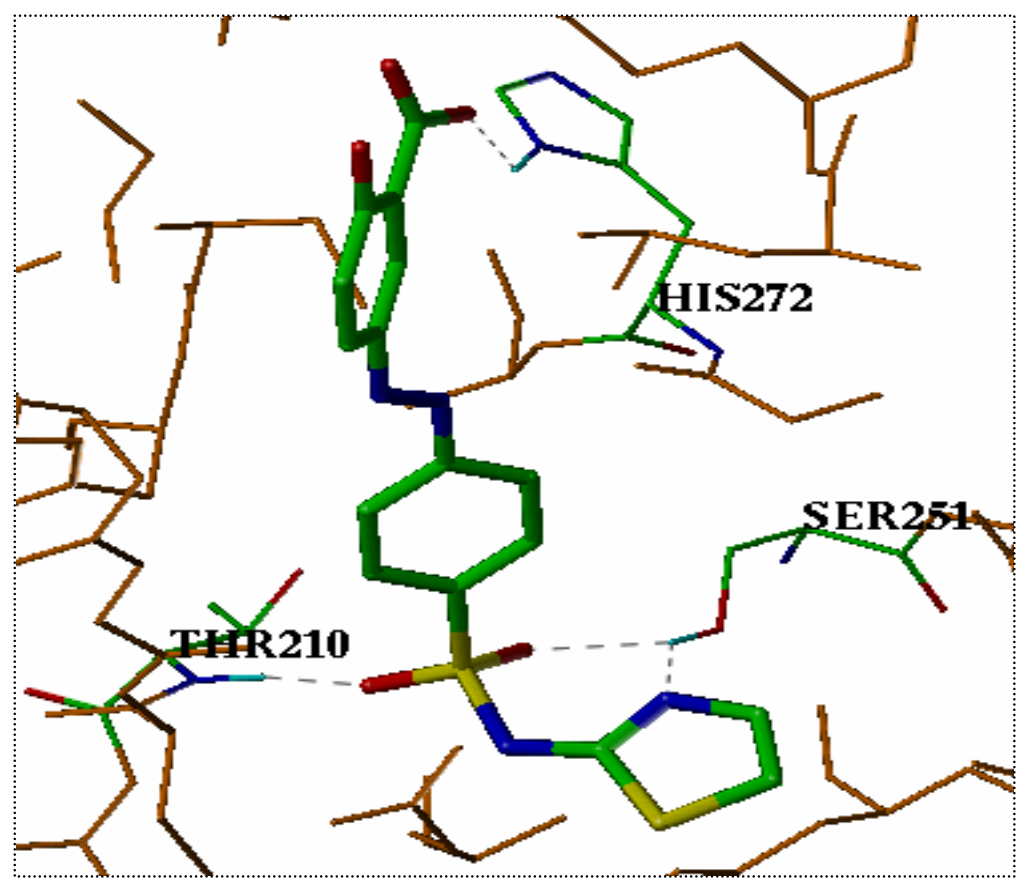

Figure 14. Hydrogen-bonding interactions between calpain 1 and compound 1.

Hydrogen atoms are removed for clarity, except those involved in hydrogen bonding. Hydrogen bonds are shown as black dashed lines. The atoms are colored as follows: all the protein residues are orange, except those involved in the hydrogen-bonding interactions; carbon = green; hydrogen $=$ cyan; nitrogen $=$ blue; oxygen $=$ red; sulfur $=$ yellow. 
of $\mathbf{1}$ and His272 is important for calpain inhibition. Reposition of the carboxylic acid group meta to the phenolic hydroxyl as $\mathbf{6}$ led to about a 10-fold decrease in calpain inhibition, which further supports the significance of the hydrogen bonding interaction or salt bridge formation between the carboxylic acid and His 272 to calpain inhibition. The thiazole ring, which formed three hydrogen bonds with active site residues, was also found to be very important for potent inhibition of calpain because removal of this group as in compound 7 resulted in about 55-fold and 6-fold decrease in calpain inhibition compared to compounds $\mathbf{1}$ and $\mathbf{6}$, respectively.

\subsubsection{Conclusion}

Three analogues of compound $\mathbf{1}$ were synthesized and studied as inhibitors of porcine erythrocyte calpain 1 . The compounds inhibited calpain 1 with $K_{\mathrm{i}}$ values ranging from $1 \mu \mathrm{M}$ to $63.2 \mu \mathrm{M}$. The thiazole ring and the carboxylic acid substitutes of 1 were found to be very important for potent calpain inhibition.

\subsection{Synthesis of Sulfonamide-Based Peptidomimetic Calpain Inhibitors}

\subsubsection{Objective}

Most active site directed calpain inhibitors incorporate an electrophilic functionality for covalent interaction with the catalytic site thiolate of the enzyme. ${ }^{13}$ This interaction was confirmed for the binding of leupeptin (PDB code 1TL9) and E64 (PDB code 1TL0) to engineered calpain 1. ${ }^{125}$ Compound 1 does not possess an electrophilic center for covalent modification of calpain. Due to the significance of such an interaction for potent calpain inhibition, we hypothesized that peptidomimetic analogues of $\mathbf{1}$ that incorporate an electrophilic functionality for covalent interaction with the catalytic site thiolate residue should be potent inhibitors of calpain. Compounds 10-19 (Figure 15) were synthesized as novel sulfonamide-based peptidomimetic analogues of $\mathbf{1}$ to test this hypothesis. Within this series, compounds 18 and 19 were synthesized as ethylene bridged analgues of diazo derivatives $\mathbf{1 5}$ and 17, respectively, since the diazo group is known to undergo reduction in vivo.

\subsubsection{Chemistry}

Compounds 10 and 11 were synthesized as shown in Scheme 2. Refluxing either 3- or 4-chlorosulfonyl benzoic acid 20 in $\mathrm{SOCl}_{2}$ followed by treating the resulting chlorosulfonyl benzoyl chloride with L-phenylalanine methyl ester hydrochloride in the presence of DIPEA gave 21, which was reacted with 2-amino-thiazole in the presence of pyridine to give sulfonamide 22 in $40 \%$ overall 


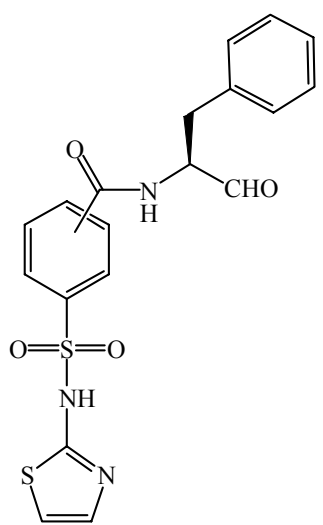

10, Para

11, Meta

12, Ortho

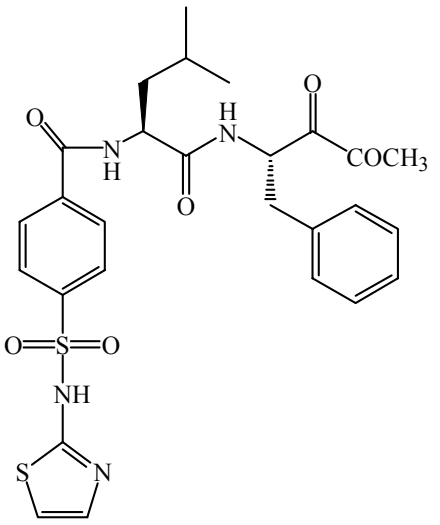

13<smiles>CC(C)C[C@H](NC(=O)c1cccc(S(=O)(=O)Nc2nccs2)c1)C(=O)N[C@@H](Cc1ccccc1)C(N)=O</smiles>

14

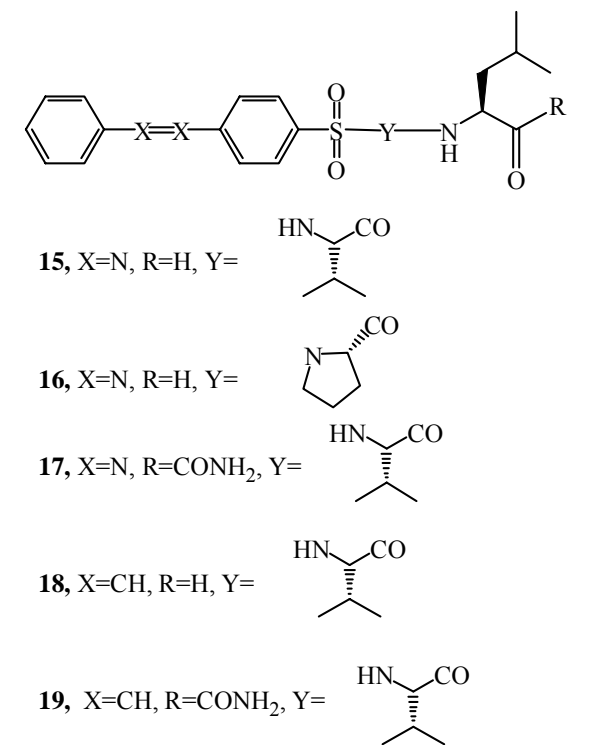

Figure 15. Sulfonamide-based peptidomimetic compounds 10-19. 


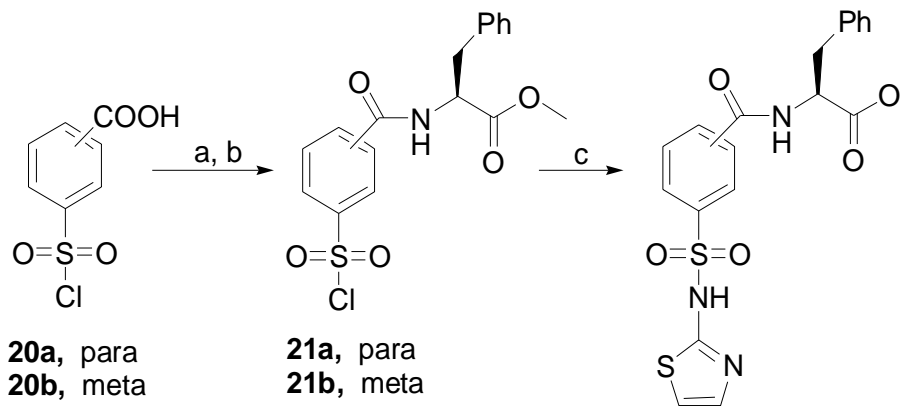

22a, para (40\% (3 steps))

22b, meta (41\% (3 steps))

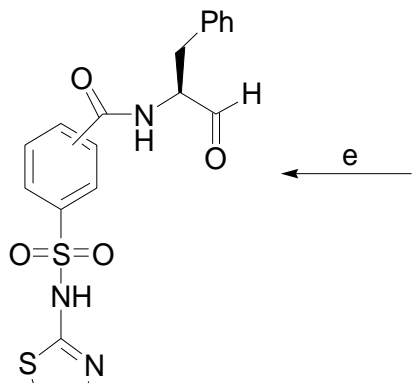

10 (52\%); 11 (51\%); 12 (55\%)

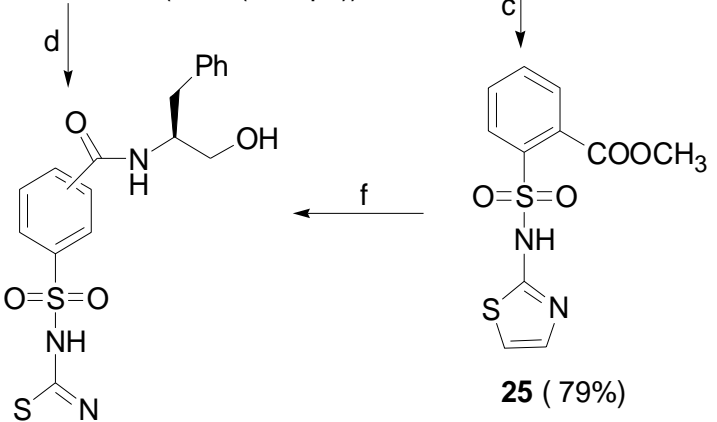

23a, para (55\%)

23b, meta $(83 \%)$

23c, ortho $(46 \%)$

Scheme 2. Synthesis of compounds 10-12.

Reagents: (a) $\mathrm{SOCl}_{2}$, 1,2-Dichloroethane, Reflux, 1 h; (b) L-Phe-OMe.HCl, DIPEA, $\mathrm{CH}_{2} \mathrm{Cl}_{2}$, RT, 1 h; (c) 2-Amino-thiazole, Pyridine, RT, 16 h; (d) $\mathrm{LiBH}_{4}, 5$ h; (e) $\mathrm{PySO}_{3}$, DMSO, $\mathrm{CH}_{2} \mathrm{Cl}_{2}$, RT, 2 h; (f) DMF, 2-Amino-3-phenyl-propanol, 1,4-dioxane, microwave at $155^{\circ} \mathrm{C}, 20 \mathrm{~min}$. 
yield. Reduction of the ester group of 22 with $\mathrm{LiBH}_{4}$ afforded alcohol 23, which was oxidized with $\mathrm{PySO}_{3}$ in DMSO/DCM mixture to give target compounds $\mathbf{1 0}$ and $\mathbf{1 1}$. Ortho substituted derivative 12 was synthesized by reacting methyl-(2-chlorosulfonyl)benzoate $\mathbf{2 4}$ with 2-amino-thiazole to give 25. Microwave assisted coupling of 25 with 2-amino-3-phenylpropanol gave 23, which was transformed to aldehyde $\mathbf{1 2}$ as described above.

Dipeptide-sulfonamides $\mathbf{1 3}$ and $\mathbf{1 4}$ were synthesized as shown in Scheme 3. The appropriate chlorosulfonyl benzoic acid 20 was refluxed in $\mathrm{SOCl}_{2}$, treated with L-valine methyl ester hydrochloride in the presence of DIPEA followed by reaction with 2-amino-thiazole and ester hydrolysis with $1.0 \mathrm{~N} \mathrm{NaOH}$ to give sulfonamide 27. This was coupled with $\mathbf{2 8}$, which was synthesized as previously reported by Donkor et $\mathrm{al}^{166}$ to give beta-hydroxy ester derivative 29. Oxidation of 29 with $\mathrm{PySO}_{3} / \mathrm{DMSO}$ mixture afforded target compound 13. Attempted hydrolysis of the ester functionality of $\mathbf{1 3}$ to obtain the $\alpha$-ketoacid derivative was unsuccessful. Treatment of $\mathbf{2 9}$ with $\mathrm{MeOH} / \mathrm{NH}_{3}$ gave $\alpha$-hydroxy- $\beta$-animo amide derivative 30 , which was oxidized with $\mathrm{PySO}_{3} / \mathrm{DMSO}$ mixture to give 14.

The synthesis of compounds 15-17 is outlined in Scheme 4. Compounds $\mathbf{1 5}$ and 16 were synthesized starting with the commercially available 4-phenylazobenzene sulfonyl chloride 31, which was treated with either L-valine methyl ester hydrochloride or L-proline methyl ester hydrochloride in the presence of DIPEA to give 32 and 33, respectively. Basic hydrolysis of the ester groups of these compounds followed by couplying with L-leucinol and oxidation with Dess-Martin reagent gave target compounds 15 and 16. The aldehyde 15 was reacted with $\mathrm{KCN}$ to give cyanohydrin 34 and hydrolysis of the cyano group gave $\alpha$-hydroxy- $\beta$-animo acid ester 35. Treatment of 35 with $\mathrm{MeOH} / \mathrm{NH}_{3}$ gave $\alpha$-hydroxy- $\beta$-animo amide 36, which was oxidized with $\mathrm{PySO}_{3} / \mathrm{DMSO}$ mixture to give 17.

The synthesis of compounds $\mathbf{1 8}$ and 19 is outlined in Scheme 5. The compounds were synthesized as described for the synthesis of diazo compounds 15-17. 4-Styrene sulfonic acid sodium salt $\mathbf{3 7}$ was converted to 4-styryl-phenylsulfonic acid sodium salt using Heck reaction, which is known to generate products with $E$ configuration. We confirmed the geometry of the compounds using 2D C-H correlation spectroscopy. Refluxing of the phenylsulfonic acid sodium salt in $\mathrm{SOCl}_{2}$ gave sulfonyl chloride 38, which was treated with L-valine methyl ester hydrochloride in the presence of DIPEA to give sulfonamide 39. Hydrolysis of the ester group of $\mathbf{3 9}$ followed by coupling of the resultant acid with L-leucinol afforded 41, which was transformed to aldehyde $\mathbf{1 8}$ and alpha-ketoamide $\mathbf{1 9}$ as described for the synthesis of the corresponding diazo derivatives $\mathbf{1 5}$ and $\mathbf{1 7}$ in Scheme 4. 


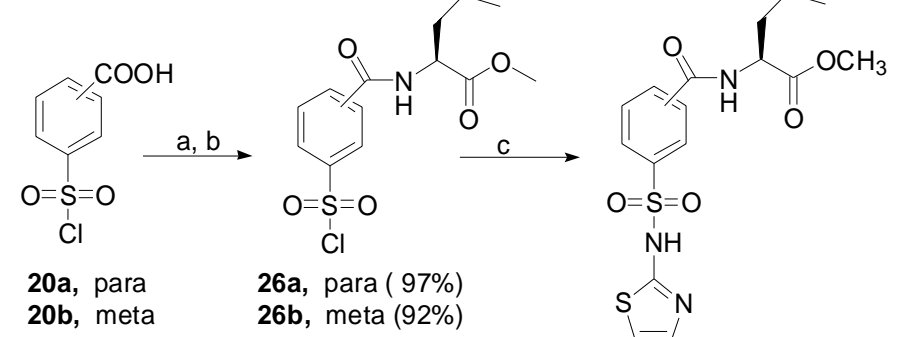

27a, para $(44 \%)$

27b, meta $(60 \%)$
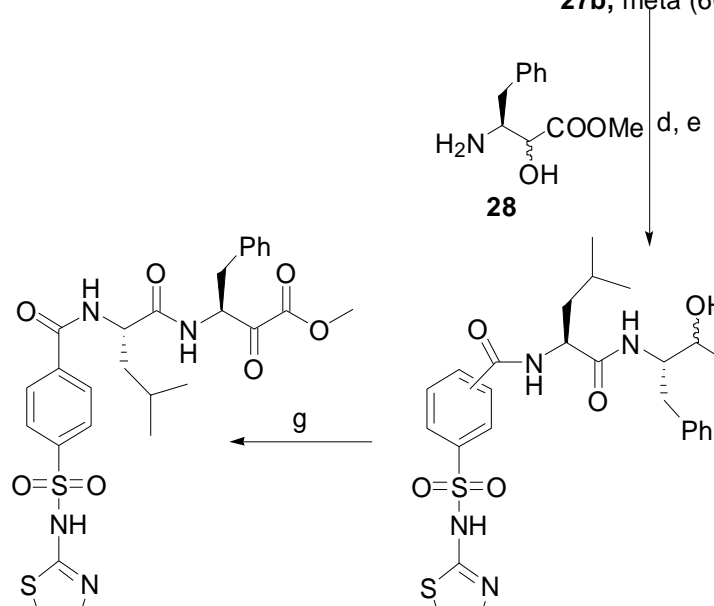

13, $(48 \%)$

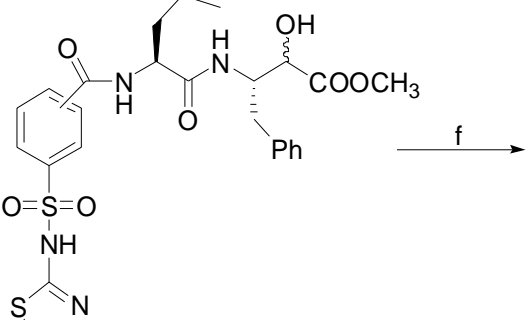

29a, pata (28\% (2steps) 29b, meta (30\% (2steps))
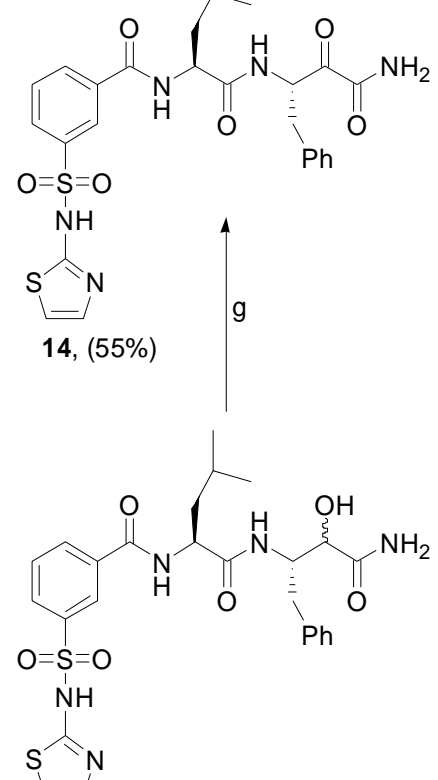

30, $(70 \%)$

Scheme 3. Synthesis of dipeptide-sulfonamides 13 and 14.

Reagents: (a) $\mathrm{SOCl}_{2}$, 1,2-Dichloroethane, Reflux, 1 h; (b) L-Val-OMe.HCl, DIPEA, $\mathrm{CH}_{2} \mathrm{Cl}_{2}$, RT, 1 h; (c) 2-Amino-thiazole, Pyridine, RT, 16 h; (d) $1.0 \mathrm{~N} \mathrm{NaOH}$; (e) HBTU, DIPEA, DMF; (f) $7.0 \mathrm{~N} \mathrm{NH}_{3}$ in $\mathrm{MeOH}, 16$ h; (g) $\mathrm{PySO}_{3}, \mathrm{DMSO}, \mathrm{CH}_{2} \mathrm{Cl}_{2}, \mathrm{RT}$, $2 \mathrm{~h}$. 


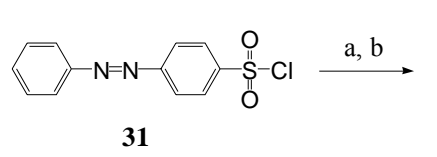

32, $\mathrm{Y}=$

$\mathrm{HN} \mathrm{COOH}$

$[92.5 \%(a) ; 75.5 \%(b)]$

33, $\mathrm{Y}=\mathrm{N}, \mathrm{COOH}$

$[87.3 \%(a) ; 87.3 \%(b)]$

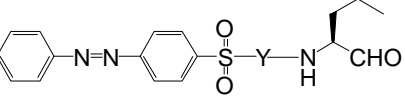

15, $\mathrm{Y}=\mathrm{HN} \sim \mathrm{CO}$

$[51 \%(\mathrm{c}) ; 50.2 \%(\mathrm{~d})]$

16, $\mathrm{Y}=\mathrm{N}-\mathrm{CO}$

$[60 \%(\mathrm{c}) ; 50.4 \%(\mathrm{~d})]$

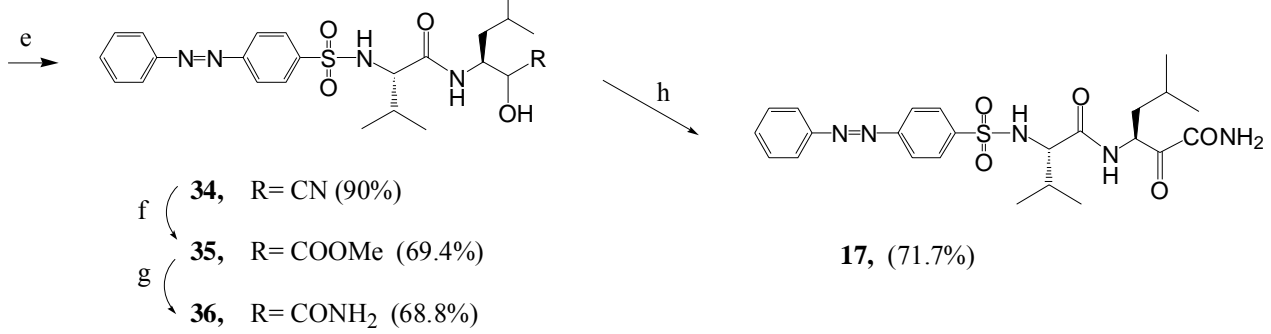

Scheme 4. Synthesis of compounds 15-17.

Reagents: (a) Pyridine, L-Val-OMe.HCl or L-Pro-OMe.HCl, RT, 20 h; (b) $1.0 \mathrm{~N}$ $\mathrm{NaOH}, \mathrm{MeOH}, 55^{\circ} \mathrm{C}, 2 \mathrm{~h}$; (c) L-leucinol, CDI, THF, $\mathrm{CH}_{2} \mathrm{Cl}_{2}$, RT, 96 h; (d)

Dess-Martin reagent, $\mathrm{CH}_{2} \mathrm{Cl}_{2}$; (e) $\mathrm{NaHSO}_{3} / \mathrm{KCN}$; (f) con. $\mathrm{HCl} / \mathrm{MeOH}$; (g) $7.0 \mathrm{~N} \mathrm{NH}_{3}$ in $\mathrm{MeOH}, 16$ h; (g) $\mathrm{PySO}_{3}$, DMSO. 


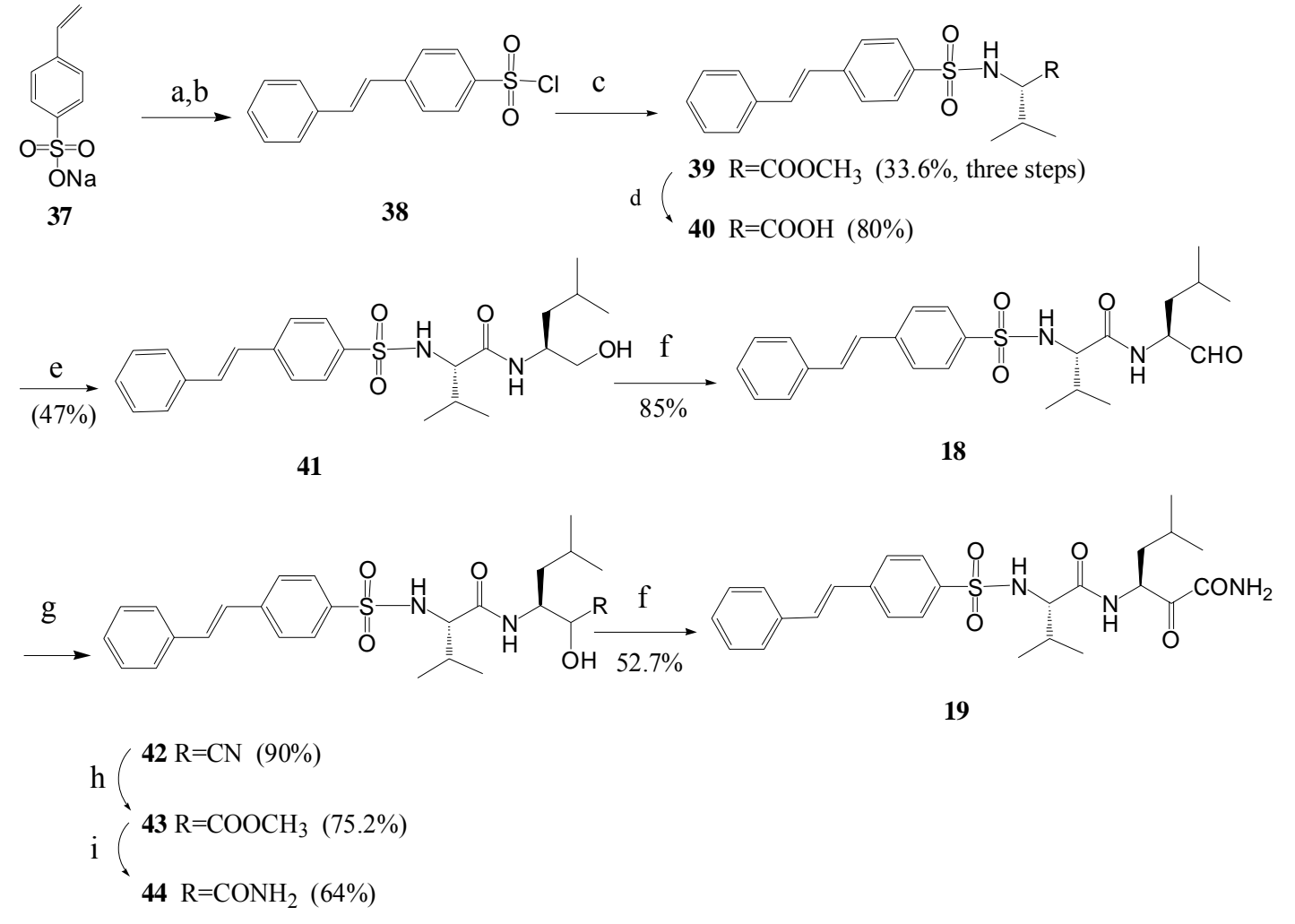

Scheme 5. Synthesis of compounds 18-19.

Reagents: (a) bromobenzene, $\mathrm{Pd}(\mathrm{OAc})_{2}$, TEA, (o-Tol) ${ }_{3} \mathrm{P}$; (b) $\mathrm{SOCl}_{2}, \mathrm{DMF}$; (c) 1-Val-OMe hydrogenchloride, DIPEA, pyridine; (d) 4.0N NaOH, $\mathrm{MeOH}$; (e) 1-leucinol, TEA, Mukayaima's regaent, DMF; (f) $\mathrm{PySO}_{3}$, DMSO; (g) $\mathrm{NaHSO}_{3} / \mathrm{KCN}$; (h) con. $\mathrm{HCl} / \mathrm{MeOH}$; (i) $7.0 \mathrm{~N} \mathrm{NH}_{3}$ in $\mathrm{MeOH}$. 


\subsubsection{Results and Discussion}

The sulfonamide-based peptidomimetic compounds 10-19 were synthesized and tested as inhibitors of porcine erythrocyte calpain 1 to test the hypothesis that derivatives of diazosulfonamide $\mathbf{1}$ that incorporate an electrophilic group for covalent interaction with Cys115 at the active site of calpain would be potent inhibitors of the enzyme. Table 2 shows the results of this study. The compounds inhibited calpain 1 with $K_{\mathrm{i}}$ values ranging from $0.009 \mu \mathrm{M}$ to $29.8 \mu \mathrm{M}$. Structure requirement study of compound 1 showed that the thiazole ring is very important for potent calpain inhibition. We therefore synthesized compounds 10-14 to determine if appending an electrophilic functionality to the phenylsulfathiazole substructure of $\mathbf{1}$ would result in potent calpain inhibition. Compounds 10-12 were designed as pseudo dipeptide derivatives while $\mathbf{1 3}$ and $\mathbf{1 4}$ were designed as pseudo-tripeptide derivatives. Generally, the pseudo-tripeptides were more potent calpain inhibitors than the pseudo-dipeptide derivatives. Compound 14 with $K_{\mathrm{i}}$ of $62 \mathrm{nM}$ was the most potent member of the series. The position of the peptidyl substitute influenced calpain inhibition with the meta position (as in $\mathbf{1 1}$ and 14) being the most preferred position and the ortho position (as in 12) being the least preferred position.

Calpain inhibitors such as MDL28170 were discovered as a result of $\mathrm{N}$-terminal capping of dipeptide aldehyde inhibitors of calpain. ${ }^{13}$ The N-terminal capping group occupies the $\mathrm{S}_{3} / \mathrm{S}_{4}$ subsites of the enzyme. Compounds 15-17 were synthesized to investigate if the $N, N$ '-diphenyl sulfonyl group of compound $\mathbf{1}$ could serve an effective $\mathrm{N}$-terminal capping functionality to enhance calpain inhibition. The compounds were potent inhibitors of calpain 1 and displayed $K_{\mathrm{i}}$ values between 16 $\mathrm{nM}$ and $273 \mathrm{nM}$. Compound 15 with L-valine as the $\mathrm{P}_{2}$ substitutent was more potent than 16 with a $\mathrm{P}_{2}$ proline substitutent, which is consistent with previous reports that the $\mathrm{S}_{2}$ subsite of calpain prefers small hydrophobic groups at the $\mathrm{P}_{2}$ position of inhibitors. ${ }^{13}$ The alpha-ketoamides 17 and 19 were as potent as the corresponding aldehydes 15 and 18, respectively. The diazo bridge of $\mathbf{1}$ was not involved in hydrogen bonding interactions with active site residues (Figure 14). Therefore, we hypothesized that replacement of the diazo bridge with an ethylene linker should not be detrimental to calpain inhibition. This replacement was inspred by the fact that the diazo group of diazosulfonamides (e.g., protosil) is known to undergo reduction in vivo. Compounds 18 and 19 were then synthesized as deaza analogues of 15 and 17, respectively, and found to be potent inhibitors of calpain with $19\left(K_{\mathrm{i}}=9 \mathrm{nM}\right)$ being the most potent member of all the novel sulfonamide-based peptidomimetic inhibitors derived from diazosulfonamide $\mathbf{1}$. Indeed, compound 19 is one of the most potent calpain inhibitors known to date. This compound is especially interesting because it is an alpha-ketoamide derivative and so unlike aldehyde calpain inhibitors should not undergo oxidation of the critical electrophilic functionality in vivo. Thus, $\mathbf{1 9}$ should have longer in vivo exposure compared to its aldehyde congener 18 however this awaits future pharmacokinetic investigation. 
Table 2. Inhibition of Porcine Erythrocyte Calpain 1 by Compounds 10-19.

\begin{tabular}{cc}
\hline Compound & ${ }^{\mathrm{a}} K_{\mathrm{i}}(\mu \mathrm{M})$ \\
& \\
\hline $\mathbf{1 0}$ & \\
$\mathbf{1 1}$ & 4.36 \\
$\mathbf{1 2}$ & 0.5 \\
$\mathbf{1 3}$ & 29.8 \\
$\mathbf{1 4}$ & 8.42 \\
$\mathbf{1 5}$ & 0.062 \\
$\mathbf{1 6}$ & 0.018 \\
$\mathbf{1 7}$ & 0.273 \\
$\mathbf{1 8}$ & 0.016 \\
$\mathbf{1 9}$ & 0.014 \\
& 0.009 \\
\hline
\end{tabular}

${ }^{\mathrm{a}} K_{\mathrm{i}}$ values were determined by plotting $1 / v$ versus $I$ to give intersecting lines with correlation coefficient $\geq 0.95$. 


\subsubsection{Conclusion}

Sulfonamide-based peptidomimetic compounds 10-19 have been synthesized as potent calpain 1 inhibitors. The compounds are hybrid molecules of substructures derived from diazosulfonamide $\mathbf{1}$ and dipeptide aldehyde and dipeptide alpha-ketoamides. Introduction of the electrophilic functionality (i.e., the aldehyde and alpha-ketoamide) groups significantly enhanced calpain inhibition.

Sulfonamide-based peptidomimetic analogue 19 with $K_{\mathrm{i}}$ of $9 \mathrm{nM}$ was the most potent member of the series. It is twice as potent as MDL28170 $\left(K_{\mathrm{i}}=20 \mathrm{nM}\right)$ and over 100 -fold more potent than the lead diazosulfonamide 1. 


\section{CHAPTER 3. DETERMINATION OF THE ANTI-TUMOR ACTIVITY OF THE SULFONAMIDE-BASED PEPTIDOMIMETIC CALPAIN INHIBITORS}

\subsection{Objective}

Cancer is thought to be deficiency or upregulated function/expression of certain functional proteins, which are substrates of various proteolytic enzymes. Hence, it is possible to influence a cascade of signal transduction events by regulating the activity of a single proteolytic enzyme. As discussed in the introduction (Section 1.3.4), calpain is one of these proteolytic enzymes and has been implicated a molecular target for cancer therapy. Currently, $75 \%$ of cancer deaths are due to epithelial cancers. The five year survival rates for patients with disseminated melanoma is less than 5\% with an average survival time of 6-10 months. ${ }^{167}$ Common anticancer drugs, such as taxol, have shown lack of clinical efficacy. Inhibition of calpain suppresses cell growth and promotes apoptosis in a variety of human cancer cell lines. ${ }^{168-171}$ Thus, calpain could offer a novel target for the discovery of new anticancer agents.

Although $K \mathrm{i}$ values as determined in cell free system evaluate the intrinsic inhibitory potency of compounds, drug effects in whole cell systems are potentially confounded by factors including drug stability, cellular penetration and/or non-specific binding. To explore the anti-proliferative activities of calpain inhibitors in whole cell systems, a selected set of novel sulfonamide analogs and peptidomimetic inhibitors were evaluated in human melanoma cell A375 and mouse melanoma cell B16F1. Evaluation of the compounds against non-cancer cell line is going on.

\subsection{Results and Discussion}

Compounds 1, 6, 11, 12 and 15-19 were tested against A375 human melanoma cells and mouse B16F1 melanoma cells to explore the anti-proliferative activities of calpain inhibitors. Studies were performed according to the protocol described in Section 4.3 and the results are summaried in Table 3. Compounds 1, 6, 11 and 12 did not show cell growth inhibition at $20 \mu \mathrm{M}$. This could be due to poor cell penetration and/or weak calpain inhibition. The ClogP values of the compounds ranges from 2 to about 3.7 .

Compounds 15-19 showed antiproliferation activity at $20 \mu \mathrm{M}$ and were selected for determination of the concentration required to inhibit melanoma cell growth by $50 \%$ (i.e., $\mathrm{GI}_{50}$ ). The compounds displayed moderate antiproliferation activity with $\mathrm{GI}_{50}$ values ranging from $4 \mu \mathrm{M}$ to $22 \mu \mathrm{M}$. Compound 16 (Figure 15) with proline as the $\mathrm{P}_{2}$ 
Table 3. Structures and Activity of Calpain Inhibitors against Melanoma Cells (A375 and B16F1) and Porcine Erythrocyte Calpain 1.

\begin{tabular}{|c|c|c|c|c|}
\hline \multirow{2}{*}{ Compound } & A375 & $\mathrm{B} 16 \mathrm{~F} 1$ & \multirow{2}{*}{${ }^{d} K_{\mathrm{i}}(\mu \mathrm{M})$} & \multirow{2}{*}{${ }^{\mathrm{e}} \mathrm{cLog} \mathrm{P}$} \\
\hline & ${ }^{\mathrm{b}} \mathrm{GI}_{50} \pm{ }^{\mathrm{c}}$ s.e. $(\mu \mathrm{M})$ & $\mathrm{GI}_{50} \pm$ s.e. $(\mu \mathrm{M})$ & & \\
\hline Taxol & $0.009 \pm 0.001$ & $0.021 \pm 0.0009$ & & \\
\hline 1 & $\mathrm{a}$ & ND & 1.0 & 3.7 \\
\hline 6 & $\mathrm{a}$ & ND & 9.89 & 3.1 \\
\hline 11 & $\mathrm{a}$ & ND & 0.5 & 2.1 \\
\hline 12 & $\mathrm{a}$ & ND & 29.8 & 2.1 \\
\hline 15 & $12.9 \pm 1.5$ & $13.7 \pm 5.0$ & 0.018 & 5.5 \\
\hline 16 & $4.1 \pm 0.5$ & $13.7 \pm 1.7$ & 0.273 & 4.6 \\
\hline 17 & $22.3 \pm 2.1$ & $18.7 \pm 3.0$ & 0.016 & 4.0 \\
\hline 18 & $9.4 \pm 2.1$ & $10.3 \pm 1.9$ & 0.014 & 5.7 \\
\hline 19 & $16.0 \pm 1.3$ & $17.2 \pm 2.8$ & 0.009 & 4.2 \\
\hline
\end{tabular}

$\mathrm{a}=$ cell growth inhibition $<2 \%$ at $20 \mu \mathrm{M}$.

${ }^{\mathrm{b}} \mathrm{GI}_{50}=$ half maximal growth inhibition

${ }^{\mathrm{c}}$ s.e. $=$ standard error

${ }^{\mathrm{d}} K_{\mathrm{i}}$ values were determined by Dixon plots using the average of assays and plotting $1 / \mathrm{v}$ versus I to give intersecting lines with correlation coefficient $\geq 0.95$.

${ }^{e} \operatorname{cLog} \mathrm{P}$ is the calculated partition coefficients of the inhibitors and were determined with ChemDraw Ultra ver. 9.0. 
substitutent was the most effective member of the series for inhibiting the growth of the human melanoma cell line A375. Compound 16 with $K_{\mathrm{i}}$ of $273 \mathrm{nM}$ was over 3-fold more potent than 15 with $K_{\mathrm{i}}$ of $18 \mathrm{nM}$ as inhibitor of A375 cell growth. Thus, there appears to be no correlation between calpain inhibition and antiproliferation activity of the compounds. However, the compounds were equipotent versus the mouse B16F1 cell line. Generally, there was limited variability in the $\mathrm{GI}_{50}$ values of the compounds versus the mouse cell line $\left(\mathrm{GI}_{50} 10.3 \mu \mathrm{M}\right.$ to18.7 $\left.\mu \mathrm{M}\right)$ compared to the human cell line $\left(\mathrm{GI}_{50} 4.0 \mu \mathrm{M}\right.$ to $\left.22.3 \mu \mathrm{M}\right)$. Compounds 18 and 19 are deaza analogues of 15 and 17, respectively. The were more effective against the human A375 cells compared to 15 and 17 but were equipotent with these compounds versus the mouse melanoma cell line. Compounds 17 and 19 are $\alpha$-ketoamide analogues of aldehydes 15 and 18, respectively. Generally, the aldehydes were better antiproliferative agents compared to the corresponding $\alpha$-ketoamides presumably due to their greater lipophilicity, which should facilitate cell penetration. Nonetheless, $\alpha$-ketoamide 17 and $\mathbf{1 9}$ may be more interesting than aldehydes $\mathbf{1 5}$ and $\mathbf{1 8}$ due to the superior cellular stability of the $\alpha$-ketoamide warhead.

\subsection{Conclusion}

In this study, we report that the aldehyde and $\alpha$-ketoamide calpain inhibitors showed moderate $\mathrm{GI}_{50}$ values $(4 \mu \mathrm{M}$ to $22 \mu \mathrm{M})$ for the growth inhibition of both human melanoma cell line A375 and mouse melanoma cell line B16F1. Compound 16 was the most effective antiproliferative agent $\left(\mathrm{GI}_{50} 4 \mu \mathrm{M}\right)$ of the series. Compounds 18 and 19 with an ethylene bridge were better inhibitors of calpain and were also better antiproliferative agents than those with the diazo bridge (15 and 17). Besides, the ethylene brideg unlike diazo brideg will not undergo reduction in vivo. These characters make styrenephenyl group to be excellent group for further studies. 


\section{CHAPTER 4. EXPERIMENTAL SECTION}

\subsection{General}

All reagents and solvents were purchased from Sigma Aldrich, Fischer Scientific, TCI, and Calbiochem, and were used without any further purification. Thin layer chromatography (TLC) was performed on silica gel chromatogram plates purchased from Analtech, Inc. Fisher silica gel S732-25 (100-400 mesh) was used for column chromatography. Melting points were determined on a Fisher-Johns melting point apparatus and are uncorrected. Molecular masses were determined with electron spray ionization mass spectra (ESI-MS) in Bruker/Hewlett Packard Esquire LC/MS instrument. Nuclear magnetic resonance (NMR) spectra for ${ }^{1} \mathrm{H} N M R$ and ${ }^{13} \mathrm{C}$ NMR were recorded on Bruker ARX 300 instrument and Varian Inova-500 MHz.

Deuterated solvents were purchased from Cambridge Isotope Laboratories, Inc. The chemical shifts $(\delta)$ are reported in parts per million (ppm) relative to TMS, and coupling constants $(\mathrm{J})$ were reported in hertz. Splitting patterns were indicated as follows: s, singlet; d, doublet; t, triplet; m, multiplet. IR spectra (neat) were recorded on a Perkin Elmer precisely Spectrum 100 FT-IR spectrophotometer, and the representative absorption bands were reported. Microwave reactions were performed on CEM Discover Benchmate. Elemental analyses $(\mathrm{C}, \mathrm{H}, \mathrm{N})$ were performed by Atlantic Microlab Inc., Norcross, GA and are within $\pm 0.4 \%$ of the theoretical values.

\subsection{Chemistry}

\subsubsection{General Procedure}

General procedure 1. Synthesis of diazosulfonamides. The appropriate aromatic amine $(6 \mathrm{mmol})$ was dissolved in a mixture of concentrated $\mathrm{HCl}(3.4 \mathrm{~mL})$ and $\mathrm{H}_{2} \mathrm{O}(14 \mathrm{~mL})$ and diazotized by the dropwise addition of a solution of $17 \%$ $\mathrm{NaNO}_{2}(7.2 \mathrm{mmol})$ at $0{ }^{\circ} \mathrm{C}$ and the mixture was stirred $40 \mathrm{~min}$. Phenol, salicylic acid or 3-hydroxy benzoic acid (6 mmol) was dissolved in $20 \% \mathrm{NaOH}(12 \mathrm{~mL})$, cooled to $0{ }^{\circ} \mathrm{C}$, and a solution of the appropriate aryldiazonium salt was slowly added. The resultant colored mixture was stirred for $1 \mathrm{~h}$ at $0{ }^{\circ} \mathrm{C}$ and the product was precipitated by addition of $20 \% \mathrm{HCl}$. It was recovered and recrystallized from acetone/water mixture.

General procedure 2. Ester reduction. $\mathrm{LiBH}_{4}(40.4 \mathrm{mmol})$ was carefully added carefully to a solution of appropriate ester $(21.6 \mathrm{mmol})$ in anhydrous THF (75 $\mathrm{mL}$ ) at $-15^{\circ} \mathrm{C}$ for $5 \mathrm{~min}$ followed by stirring at RT for $0.5-2 \mathrm{~h}$ (checked by TLC). Excess $\mathrm{LiBH}_{4}$ was destroyed by the dropwise addition of acetone at $0{ }^{\circ} \mathrm{C}$ followed by extraction with $\mathrm{CH}_{2} \mathrm{Cl}_{2}$ and purification of the product by flash chromatography. 
General procedure 3. Dess-Martin oxidation. Dess-Martin reagent (17.2 mmol) was slowly added to an ice cooled solution of the appropriate alcohol (15.6 mmol) in anhydrous $\mathrm{CH}_{2} \mathrm{Cl}_{2}(80 \mathrm{~mL})$. After $10 \mathrm{~min}$, the ice bath was removed and the milky reaction mixture was stirred at RT for 2-4 h (checked by TLC). A solution of $\mathrm{Na}_{2} \mathrm{~S}_{2} \mathrm{O}_{3}(160 \mathrm{mmol})$ in saturated $\mathrm{NaHCO}_{3}$ was added and the mixture was stirred for additional $10 \mathrm{~min}$ at RT. After separation, the aqueous layer was extracted with $\mathrm{CH}_{2} \mathrm{Cl}_{2}(3 \times 30 \mathrm{~mL})$ and the combined organic layer was washed successively with $\mathrm{NaHCO}_{3}$ solution, water, and brine followed by drying $\left(\mathrm{MgSO}_{4}\right)$, concentration, and purification either by flash chromatography or crystallization.

General procedure 4. Pyridine-sulfur trioxide oxidation. A solution of $\mathrm{PySO}_{3}$ complex $(7.18 \mathrm{mmol})$ in DMSO $(15 \mathrm{~mL})$ was added dropwise to an ice-cooled solution of the alcohol $(0.798 \mathrm{mmol})$ and DIPEA $(7.36 \mathrm{mmol})$ in $\mathrm{CH}_{2} \mathrm{Cl}_{2} / \mathrm{DMSO}$ (30 $\mathrm{mL}$ ) and the mixture was stirred for $1 \mathrm{~h}$ at $0{ }^{\circ} \mathrm{C}$. The reaction mixture was diluted with EtOAc $(300 \mathrm{~mL})$, washed with aqueous $1 \mathrm{~N} \mathrm{HCl}(2 \times 30 \mathrm{~mL})$, saturated aqueous $\mathrm{NaHCO}_{3}(2 \times 20 \mathrm{~mL})$, and brine. The organic phase was recovered and dried over $\mathrm{MgSO}_{4}$ followed by concentrated and purification either by flash chromatography or crystallization.

\subsubsection{Synthesis of Compounds 1, 5, 6, and 7}

4-((4-Hydroxyphenyl)diazenyl)- $N$-(thiazol-2-yl)benzenesulfonamide (5). Compound 5 was synthesized as described in general procedure 1 as brown solid in $47 \%$ yield. m.p. $252-253{ }^{\circ} \mathrm{C} .{ }^{1} \mathrm{H}$ NMR (DMSO-d $) \delta 12.8(\mathrm{~s}, 1 \mathrm{H}), 10.44(\mathrm{~s}, 1 \mathrm{H})$, 7.87-7.95 (m, 4H), $7.81(\mathrm{~d}, \mathrm{~J}=9.0,2 \mathrm{H}), 7.26(\mathrm{~d}, \mathrm{~J}=4.5,1 \mathrm{H}), 6.94(\mathrm{~d}, \mathrm{~J}=9.0,2 \mathrm{H}), 6.84$ (d, J=4.5, 1H). MS (ESI) $458.9[\mathrm{M}-\mathrm{H}]^{-}$. IR $\left(\mathrm{cm}^{-1}\right) 3355(\mathrm{OH})$. Anal. Calcd. for: $\mathrm{C}_{15} \mathrm{H}_{12} \mathrm{~N}_{4} \mathrm{O}_{3} \mathrm{~S}_{2}, \mathrm{C}, 49.99 ; \mathrm{H}, 3.36 ; \mathrm{N}, 15.55 ; \mathrm{S}, 17.79$. Found: C, 49.81; H, 3.37; N, 15.47; S, 17.75 .

2-Hydroxy-5-((4-( $N$-thiazol-2-ylsulfamoyl)phenyl)diazenyl)benzoic acid (1) Compound 1 was obtained as brown solid in $47.8 \%$ yield using the general procedure 1. m.p. $252-254{ }^{\circ} \mathrm{C} .{ }^{1} \mathrm{H}$ NMR (DMSO-d $) ~ \delta 12.87(\mathrm{~s}, 1 \mathrm{H}), 8.36(\mathrm{~d}, \mathrm{~J}=2.7,1 \mathrm{H}), 8.11(\mathrm{~d}$, $\mathrm{J}=2.4,1 \mathrm{H}), 8.08(\mathrm{~d}, \mathrm{~J}=2.7,1 \mathrm{H}), 7.98(\mathrm{~s}, 3 \mathrm{H}), 7.29(\mathrm{~d}, \mathrm{~J}=4.5,1 \mathrm{H}), 7.17(\mathrm{~d}, \mathrm{~J}=4.5,1 \mathrm{H})$, 6.87 (d, J=4.8, 1H). MS (ESI) 402.9 [M-H] $]^{-}$IR ( cm $^{-1}$ ) 3013 and 3095 (br, OH), 1659 $(\mathrm{C}=\mathrm{O})$. Anal. Calcd. for: $\mathrm{C}_{16} \mathrm{H}_{12} \mathrm{~N}_{4} \mathrm{O}_{5} \mathrm{~S}_{2} \bullet 0.375 \mathrm{H}_{2} \mathrm{O}, \mathrm{C}, 46.74 ; \mathrm{H}, 3.13 ; \mathrm{N}, 13.63 ; \mathrm{S}$, 15.60. Found: C, 46.75; H, 3.15; N, 13.61; S, 15.59 .

5-Hydroxy-2-((4-( $N$-thiazol-2-ylsulfamoyl)phenyl)diazenyl)benzoic acid (6). Compound 6 was obtained as brown solid in $40.8 \%$ yield as described in general procedure 1. m.p.213-214 ${ }^{\circ} \mathrm{C} .{ }^{1} \mathrm{H}$ NMR (DMSO-D6) $\delta 12.98(\mathrm{br}, 2 \mathrm{H}), 10.66(\mathrm{~s}, 1 \mathrm{H})$, $7.95(\mathrm{~d}, \mathrm{~J}=8.7,2 \mathrm{H}), 7.84(\mathrm{~d}, \mathrm{~J}=8.7,2 \mathrm{H}), 7.65(\mathrm{~d}, \mathrm{~J}=8.7,1 \mathrm{H}), 7.25(\mathrm{~d}, \mathrm{~J}=4.8,1 \mathrm{H})$, 6.97-7.04 (m, 2H), 6.84 (d, J=4.8, 1H). MS (ESI) 402.9 [M-H] $]^{-}$IR $\left(\mathrm{cm}^{-1}\right) 3339(\mathrm{OH})$, 
$1713(\mathrm{C}=\mathrm{O})$. Anal. Calcd. for: $\mathrm{C}_{16} \mathrm{H}_{12} \mathrm{~N}_{4} \mathrm{O}_{5} \mathrm{~S}_{2} \bullet 0.25$ EtOAc. C, 47.88; H, 3.31; N, 13.14; S, 15.04. Found: C, 47.59; H, 3.40; N, 13.06; S, 14.87.

5-Hydroxy-2-((4-sulfamoylphenyl)diazenyl)benzoic acid (7) Compound 7 was obtained as brown solid in $35.5 \%$ yield by following general procedure 1. m.p. 245-247 ${ }^{\circ}$. ${ }^{1} \mathrm{H}$ NMR (DMSO-d 6 ) $\delta 7.97$ (d, J=8.4, 2H), 7.87 (d, J=8.4, 2H), 7.66 (d, $\mathrm{J}=8.7,1 \mathrm{H}), 7.48(\mathrm{~s}, 2 \mathrm{H}), 6.97-7.04(\mathrm{~m}, 2 \mathrm{H}) . \mathrm{MS}(\mathrm{ESI}) 319.8[\mathrm{M}-\mathrm{H}]^{-} . \mathrm{IR}\left(\mathrm{cm}^{-1}\right) 3383$ and $3361(\mathrm{NH}), 1717(\mathrm{C}=\mathrm{O})$. Anal. Calcd. for: $\mathrm{C}_{13} \mathrm{H}_{11} \mathrm{~N}_{3} \mathrm{O}_{5} \mathrm{~S}, \mathrm{C}, 48.60 ; \mathrm{H}, 3.45 ; \mathrm{N}$, 13.08; S, 9.98. Found: C, 48.40; H, 3.49; N, 13.04; S, 9.94.

\subsubsection{Synthesis of Compounds 10, 11 and 12}

(S)-Methyl 3-phenyl-2-(4-( $N$-thiazol-2-ylsulfamoyl)benzamido)propanoate (22a). 4-Chlorosulfonyl benzoic acid $(5.0 \mathrm{~g}, 22.7 \mathrm{mmol})$ was dissolved in a mixture of $\mathrm{SOCl}_{2}(20 \mathrm{~mL})$ and 1,2-dichloroethane $(10 \mathrm{~mL})$ and refluxed for $1 \mathrm{~h}$. The solvent was removed under vacuum to give a light-brown solid. The solid was dissolved in anhydrous $\mathrm{CH}_{2} \mathrm{Cl}_{2}(25 \mathrm{~mL})$ followed by the addition of L-phenylalanine methyl ester hydrochloride $(5.14 \mathrm{~g}, 23.8 \mathrm{mmol})$ in anhydrous $\mathrm{CH}_{2} \mathrm{Cl}_{2}(25 \mathrm{~mL})$ containing DIEA $\left(4.0 \mathrm{~mL}\right.$ ) at $-20{ }^{\circ} \mathrm{C}$. The mixture was stirred for $30 \mathrm{~min}$ at $-15^{\circ} \mathrm{C}$ to $0{ }^{\circ} \mathrm{C}$ and then at RT for another $1 \mathrm{~h}$. It was washed with $\mathrm{NaHCO}_{3}$ solution, brine, dried $\left(\mathrm{MgSO}_{4}\right)$, and concentrated to give a solid, which was added to a solution of 2-aminothiazole (3.5 g, $34.59 \mathrm{mmol})$ in pyridine $(20 \mathrm{~mL})$. After stirring for $17 \mathrm{~h}$, the solution was poured into $2 \mathrm{~N} \mathrm{HCl}$ and extracted with EtOAc $(3 \times 50 \mathrm{~mL})$. The combined extract was washed successively with water and brine, dried $\left(\mathrm{MgSO}_{4}\right)$, concentrated, and purified by flash chromatography (acetone/hexane, 4:3) to give a white solid in 40\% yield. m.p. 95-99 ${ }^{\circ} \mathrm{C} .{ }^{1} \mathrm{H}$ NMR (DMSO-d $\left.{ }_{6}\right) \delta 12.85(\mathrm{~s}, 1 \mathrm{H}), 9.04(\mathrm{~d}, \mathrm{~J}=7.5,1 \mathrm{H}), 7.88(\mathrm{~s}, 4 \mathrm{H}), 7.19-7.28$ $(\mathrm{m}, 6 \mathrm{H}), 6.86(\mathrm{~d}, \mathrm{~J}=3.3,1 \mathrm{H}), 4.63-4.68(\mathrm{~m}, 1 \mathrm{H}), 3.64(\mathrm{~s}, 3 \mathrm{H}), 3.03-3.21(\mathrm{~m}, 2 \mathrm{H}) . \mathrm{MS}$ (ESI) $443.9[\mathrm{M}-\mathrm{H}]^{-}$. IR $\left(\mathrm{cm}^{-1}\right) 3102(\mathrm{NH}), 1736$ and $1643(\mathrm{C}=\mathrm{O})$.

(S)- $N$-(1-Hydroxy-3-phenylpropan-2-yl)-4-( $N$-thiazol-2-ylsulfamoyl)benzamide (23a). Compound 22a (3.8 g, $8.5 \mathrm{mmol})$ was reduced to 23a as described under general procedure 2 . The crude product was purified by flash chromatography $\left(\mathrm{CH}_{2} \mathrm{Cl}_{2}\right.$ /acetone, $\left.2: 1\right)$ to give a white solid in $54.8 \%$ yield. m.p. $147-155^{\circ} \mathrm{C} .{ }^{1} \mathrm{H}$ NMR $\left(\mathrm{DMSO}^{6} \mathrm{~d}^{6}\right) \delta 12.84(\mathrm{~s}, 1 \mathrm{H}), 8.35(\mathrm{~d}, \mathrm{~J}=8.4,1 \mathrm{H}), 7.87(\mathrm{dd}, \mathrm{J}=8.4,14.4,4 \mathrm{H}), 7.12-7.28$ $(\mathrm{m}, 6 \mathrm{H}), 6.86(\mathrm{~d}, \mathrm{~J}=4.5,1 \mathrm{H}), 4.85(\mathrm{t}, \mathrm{J}=5.4,1 \mathrm{H}), 4.10-4.19(\mathrm{~m}, 1 \mathrm{H}), 3.40-3.52(\mathrm{~m}$, 2H), $2.94(\mathrm{dd}, \mathrm{J}=5.1,13.8,1 \mathrm{H}), 2.77(\mathrm{dd}, \mathrm{J}=9.0,13.8,1 \mathrm{H})$. MS (ESI) $416.0[\mathrm{M}-\mathrm{H}]^{-}$. IR $\left(\mathrm{cm}^{-1}\right) 3260$ and $3104(\mathrm{NH}$ and $\mathrm{OH}), 1639(\mathrm{C}=\mathrm{O})$.

(S)- $N$-(1-Oxo-3-phenylpropan-2-yl)-4-( $N$-thiazol-2-ylsulfamoyl)benzamide (10). Oxidation of 23a (1.0 g, $2.4 \mathrm{mmol})$ with $\mathrm{PySO}_{3}$ complex as described under general procedure 4 and purification of the crude product by flash chromatography $\left(\mathrm{CH}_{2} \mathrm{Cl}_{2}\right.$ /acetone, 2:1) gave 10 as a white solid in 52.25\% yield. m.p.103-107 ${ }^{\circ} \mathrm{C} .{ }^{1} \mathrm{H}$ NMR $\left(D_{M S O}-d_{6}\right) \delta 12.84(\mathrm{~s}, 1 \mathrm{H}), 9.61(\mathrm{~s}, 1 \mathrm{H}), 9.06(\mathrm{~d}, \mathrm{~J}=7.5,1 \mathrm{H}), 7.81-7.94(\mathrm{~m}$, 
4H), 7.15-7.30 (m, 6H), $6.86(\mathrm{~d}, \mathrm{~J}=4.5,1 \mathrm{H}), 4.50-4.57(\mathrm{~m}, 1 \mathrm{H}), 3.28$ (dd, J=5.2, 13.8, 1H), $2.91(\mathrm{dd}, \mathrm{J}=10.5,13.8,1 \mathrm{H})$. MS (ESI) $413.9[\mathrm{M}-\mathrm{H}]^{-}, 446.0[\mathrm{M}+\mathrm{MeOH}-\mathrm{H}]^{-}$. IR $\left(\mathrm{cm}^{-1}\right) 3313(\mathrm{NH}), 1731$ and $1642(\mathrm{C}=\mathrm{O})$. Anal. Calcd. for: $\mathrm{C}_{19} \mathrm{H}_{17} \mathrm{~N}_{3} \mathrm{O}_{4} \mathrm{~S}_{2} \bullet 0.5 \mathrm{H}_{2} \mathrm{O}, \mathrm{C}$, 53.76; H, 4.27; N, 9.90; S, 15.11. Found: C, 53.98; H, 4.53; N, 9.58; S, 15.17.

(S)-Methyl 3-phenyl-2-(3-( $\mathrm{N}$-thiazol-2-ylsulfamoyl)benzamido)propanoate (22b) 3-Chlorosulfonyl benzoic acid $(7.0 \mathrm{~g}, 31.7 \mathrm{mmol})$ was dissolved in a mixture of $\mathrm{SOCl}_{2}(28 \mathrm{~mL})$ and 1,2-dichloroethane $(14 \mathrm{~mL})$ and refluxed for $1.5 \mathrm{~h}$. The solvent was removed under vacuum and the residue was dissolved in anhydrous $\mathrm{CH}_{2} \mathrm{Cl}_{2}$ (35 $\mathrm{mL}$ ) followed by the addition of L-Phe-OMe hydrochloride $(7.18 \mathrm{~g}, 33.3 \mathrm{mmol})$ in anhydrous $\mathrm{CH}_{2} \mathrm{Cl}_{2}(35 \mathrm{~mL})$ containing DIEA $(5.8 \mathrm{~mL})$ at $-20{ }^{\circ} \mathrm{C}$. The mixture was stirred for $30 \mathrm{~min}$ at $-15^{\circ} \mathrm{C}$ to $0{ }^{\circ} \mathrm{C}$ and at RT for another $1 \mathrm{~h}$. The mixture was then washed with $\mathrm{NaHCO}_{3}$ solution, brine, and dried $\left(\mathrm{MgSO}_{4}\right)$. The solvent was removed under vacuum and the product was recovered and added to a solution of 2-aminothiazole $(3.49 \mathrm{~g}, 34.87 \mathrm{mmol})$ in pyridine $(30 \mathrm{~mL})$. After stirring for $17 \mathrm{~h}$ at RT, the mixture was poured into $2 \mathrm{~N} \mathrm{HCl}$ and extracted with EtOAc $(4 \times 70 \mathrm{~mL})$. The combined organic layer was washed successively with water and brine, dried $\left(\mathrm{MgSO}_{4}\right)$, concentrated, and purified by flash chromatography (acetone/hexane, 1:1) to give a white solid in $41 \%$ yield. m.p. $149-152{ }^{\circ} \mathrm{C} .{ }^{1} \mathrm{H}$ NMR (acetone- $d_{6}$ ) $\delta$ 8.26-8.31 (m, 2H), $8.00(\mathrm{~d}, \mathrm{~J}=7.8,2 \mathrm{H}), 7.59(\mathrm{t}, \mathrm{J}=7.8,1 \mathrm{H}), 7.17-7.34(\mathrm{~m}, 6 \mathrm{H}), 6.81(\mathrm{~d}$, $\mathrm{J}=4.5,1 \mathrm{H}), 4.88-4.95(\mathrm{~m}, 1 \mathrm{H}), 3.69(\mathrm{~s}, 3 \mathrm{H}), 3.29(\mathrm{dd}, \mathrm{J}=5.4,13.8,1 \mathrm{H}), 3.16(\mathrm{dd}$, $\mathrm{J}=9.3,13.8,1 \mathrm{H})$. MS (ESI) $443.9[\mathrm{M}-\mathrm{H}]^{-}$. IR $\left(\mathrm{cm}^{-1}\right) 3102(\mathrm{NH}), 1738$ and 1648 $(\mathrm{C}=\mathrm{O})$.

(S)- $N$-(1-Hydroxy-3-phenylpropan-2-yl)-3-( $N$-thiazol-2-ylsulfamoyl)benzamide (23b). Compound 22b (3.2 g, $7.2 \mathrm{mmol}$ ) was reduced as described under general procedure 2 followed by flash chromatographic purification (acetone/hexane, 3:2) to give 23b as light yellow in solid $83.37 \%$ yield. m.p. $132-140{ }^{\circ} \mathrm{C} .{ }^{1} \mathrm{H}$ NMR $\left(\mathrm{DMSO}_{6}\right) \delta 12.80(\mathrm{~s}, 1 \mathrm{H}), 8.47(\mathrm{~d}, \mathrm{~J}=8.4,1 \mathrm{H}), 8.22(\mathrm{~s}, 1 \mathrm{H}), 7.98(\mathrm{~d}, \mathrm{~J}=7.8,1 \mathrm{H})$, $7.91(\mathrm{~d}, \mathrm{~J}=7.8,1 \mathrm{H}), 7.61(\mathrm{t}, \mathrm{J}=7.8,1 \mathrm{H}), 7.15-7.28(\mathrm{~m}, 6 \mathrm{H}), 6.86(\mathrm{~d}, \mathrm{~J}=4.5,1 \mathrm{H}), 4.85(\mathrm{t}$, $\mathrm{J}=5.4,1 \mathrm{H}), 4.16-4.18(\mathrm{~m}, 1 \mathrm{H}), 3.42-3.54(\mathrm{~m}, 3 \mathrm{H}), 2.95(\mathrm{dd}, \mathrm{J}=5.1,13.8,1 \mathrm{H}), 2.79(\mathrm{dd}$, $\mathrm{J}=9.3,13.8,1 \mathrm{H})$. MS (ESI) $416.0[\mathrm{M}-\mathrm{H}]^{-}$. IR $\left(\mathrm{cm}^{-1}\right) 3316(\mathrm{NH}$ and $\mathrm{OH}), 1637(\mathrm{C}=\mathrm{O})$.

(S)- $N$-(1-Oxo-3-phenylpropan-2-yl)-3-( $N$-thiazol-2-ylsulfamoyl)benzamide (11). Oxidation of 23b (500 mg, $1.199 \mathrm{mmol})$ with $\mathrm{PySO}_{3}$ complex as described under general procedure 4 and purification of the crude product by recrystallization from acetone/hexane to give $\mathbf{1 1}$ as a white solid in $50.6 \%$ yield. m.p. $180-182{ }^{\circ} \mathrm{C} .{ }^{1} \mathrm{H}$ NMR $\left(\mathrm{DMSO}_{6}\right) \delta 12.81(\mathrm{~s}, 1 \mathrm{H}), 9.62(\mathrm{~s}, 1 \mathrm{H}), 9.18(\mathrm{~d}, \mathrm{~J}=7.5,1 \mathrm{H}), 8.26(\mathrm{t}, \mathrm{J}=1.5,1 \mathrm{H})$, 7.94-8.02 (m, 2H), $7.65(\mathrm{t}, \mathrm{J}=7.8,1 \mathrm{H}), 7.17-7.29(\mathrm{~m}, 6 \mathrm{H}), 6.87(\mathrm{~d}, \mathrm{~J}=4.5,1 \mathrm{H})$, 4.51-4.58 (m, 1H), 2.89-3.27 (m, 2H). MS (ESI) 414.0 [M-H]-. IR $\left(\mathrm{cm}^{-1}\right) 3248(\mathrm{NH})$, 1732 and $1637(\mathrm{C}=\mathrm{O})$. Anal. Calcd. for: $\mathrm{C}_{19} \mathrm{H}_{17} \mathrm{~N}_{3} \mathrm{O}_{4} \mathrm{~S}_{2} \bullet 0.25 \mathrm{H}_{2} \mathrm{O}, \mathrm{C}, 54.34 ; \mathrm{H}, 4.20 ; \mathrm{N}$, 10.00; S, 15.27. Found: C, 54.08; H, 4.38; N, 9.81; S, 15.35. 
Methyl 2-( $N$-thiazol-2-ylsulfamoyl)benzoate (25). Methyl (2-sulfonyl chloride) benzoate ( $4 \mathrm{~g}, 17.0 \mathrm{mmol})$ was added to a solution of 2-aminothiazole (1.88 $\mathrm{g}, 18.7 \mathrm{mmol})$ in pyridine $(20 \mathrm{~mL})$ and stirred for $100 \mathrm{~h}$ at RT followed by heating at $55{ }^{\circ} \mathrm{C}$ for another $2 \mathrm{~h}$. The mixture was poured into $4 \mathrm{~N} \mathrm{HCl}$ and extracted with EtOAc $(3 \times 25 \mathrm{~mL})$. The combined extract was washed successively with water and brine, dried $\left(\mathrm{MgSO}_{4}\right)$, concentrated, and purified by flash chromatography (ethyl acetate/hexane, 3:2) to give a brown solid in 78.7\% yield. m.p. $202-205{ }^{\circ} \mathrm{C} .{ }^{1} \mathrm{H}$ NMR $\left(\right.$ DMSO- $\left._{6}\right) \delta 12.78(\mathrm{~s}, 1 \mathrm{H}), 7.91-7.94(\mathrm{~m}, 1 \mathrm{H}), 7.63-6.68(\mathrm{~m}, 2 \mathrm{H}), 7.51-7.54(\mathrm{~m}, 1 \mathrm{H})$, $7.28(\mathrm{~d}, \mathrm{~J}=4.8,1 \mathrm{H}), 6.86(\mathrm{~d}, \mathrm{~J}=4.5,1 \mathrm{H}), 3.75(\mathrm{~s}, 3 \mathrm{H})$. MS (ESI) $321.1[\mathrm{M}+\mathrm{H}]^{+}, \mathrm{IR}$ $\left(\mathrm{cm}^{-1}\right) 3135(\mathrm{NH}), 1726(\mathrm{C}=\mathrm{O})$.

(S)-N-(1-Hydroxy-3-phenylpropan-2-yl)-2-( $N$-thiazol-2-ylsulfamoyl)benzamide (23c). Compound 25 (233 mg, $78.2 \mathrm{mmol}$ ) and 2-amino-3-phenyl-propanol (177 $\mathrm{mg}, 1.17 \mathrm{mmol})$ were dissolved in a mixture of DMF (2 mL), 1,4-dioxane (3 mL), and 2 drops TEA and heated in a microwave at $155^{\circ} \mathrm{C}, 100 \mathrm{w}$ and $100 \mathrm{psi}$ for $20 \mathrm{~min}$. The solvent was removed in vacuo and a few drops of $0.5 \mathrm{~N} \mathrm{HCl}$ were added followed by recrystallization from acetone/hexane to give a light yellow solid in 35.8\% yield. m.p. 99-109 ${ }^{\circ} \mathrm{C} .{ }^{1} \mathrm{H}$ NMR (DMSO-d $)_{6} \delta 12.63(\mathrm{~s}, 1 \mathrm{H}), 8.02(\mathrm{~d}, \mathrm{~J}=8.4,1 \mathrm{H}), 7.88-7.91(\mathrm{~m}$, $1 \mathrm{H}), 7.51-7.61(\mathrm{~m}, 2 \mathrm{H}), 7.14-7.33(\mathrm{~m}, 7 \mathrm{H}), 6.85(\mathrm{~d}, \mathrm{~J}=4.5,1 \mathrm{H}), 4.57$ (br, $1 \mathrm{H})$, 4.03-4.12 (m, 1H), 3.39-3.58 (m, 2H), $2.91(\mathrm{dd}, \mathrm{J}=6.0,13.5,1 \mathrm{H}), 2.77(\mathrm{dd}, \mathrm{J}=8.4$, 13.8, 1H). MS (ESI) $416.0[\mathrm{M}-\mathrm{H}]^{-}, 440.1[\mathrm{M}+\mathrm{Na}]^{+}$. IR $\left(\mathrm{cm}^{-1}\right) 3583,3419$ and 3258 $(\mathrm{NH}$ and $\mathrm{OH}), 1650(\mathrm{C}=\mathrm{O})$.

(S)- $N$-(1-Oxo-3-phenylpropan-2-yl)-2-( $N$-thiazol-2-ylsulfamoyl)benzamide (12). Oxidation of 23c (460 mg, $1.10 \mathrm{mmol}$ ) with $\mathrm{PySO}_{3}$ complex as described under general procedure 4 followed by flash chromatographic (ethyl acetate $/ \mathrm{CH}_{2} \mathrm{Cl}_{2}, 3: 1$ ) purification gave 12 as a white solid in 55.16\% yield. m.p. $119-121{ }^{\circ} \mathrm{C}$. ${ }^{1} \mathrm{H}$ NMR (acetone- $\left.d_{6}\right) \delta 9.82(\mathrm{~s}, 1 \mathrm{H}), 7.86-8.21(\mathrm{~m}, 2 \mathrm{H}), 7.18-7.64(\mathrm{~m}, 9 \mathrm{H}), 6.80-7.03(\mathrm{~m}, 1 \mathrm{H})$, 4.50-4.57 (m, 1H), 2.56-3.31 (m, 2H). MS (ESI) $414.1[\mathrm{M}-\mathrm{H}]^{-}, 445.9[\mathrm{M}+\mathrm{MeOH}-\mathrm{H}]^{-}$. IR $\left(\mathrm{cm}^{-1}\right) 3315(\mathrm{NH}), 1731(\mathrm{CHO}), 1647(\mathrm{C}=\mathrm{O})$. Anal. Calcd. for:

$\mathrm{C}_{19} \mathrm{H}_{17} \mathrm{~N}_{3} \mathrm{O}_{4} \mathrm{~S}_{2} \bullet 0.5 \mathrm{H}_{2} \mathrm{O}, \mathrm{C}, 53.76 ; \mathrm{H}, 4.27 ; \mathrm{N}, 9.90 ; \mathrm{S}, 15.11$. Found: C, 53.55; H, 4.37; N, 9.64; S, 15.43.

\subsubsection{Synthesis of Compounds 13 and 14}

(S)-Methyl 2-(4-(chlorosulfonyl)benzamido)-4-methylpentanoate (26a). A solution of 4-chlorosulfonyl benzoic acid $(7.0 \mathrm{~g}, 31.7 \mathrm{mmol})$ in 1,2-dichloroethane $(14 \mathrm{~mL})$ and $\mathrm{SOCl}_{2}(30 \mathrm{~mL})$ was reflux for $1.5 \mathrm{~h}$ and the solvent was removed in vacuo to give a light-brown solid. The solid was dissolved in anhydrous $\mathrm{CH}_{2} \mathrm{Cl}_{2}$ (40 $\mathrm{mL}$ ) followed by the addition of L-leucine methyl ester hydrochloride (8.64 g, 47.59 mmol) in anhydrous $\mathrm{CH}_{2} \mathrm{Cl}_{2}(30 \mathrm{~mL})$ containing DIPEA $(8.0 \mathrm{~mL})$. The mixture was cooled at $-20{ }^{\circ} \mathrm{C}$ and stirred for $30 \mathrm{~min}$. The temperature was allowed to rise to RT and stirred for another $1.5 \mathrm{~h}$. The crude product was purified by column 
chromatography (ethyl acetate/hexane 1:3) to give a light yellow liquid in $90 \%$ yield. ${ }^{1} \mathrm{H} \mathrm{NMR}\left(\mathrm{CDCl}_{3}\right) \delta$ 7.97-8.12 (m, 4H), $6.78(\mathrm{~d}, \mathrm{~J}=8.1,1 \mathrm{H}), 4.83-4.89(\mathrm{~m}, 1 \mathrm{H}), 3.80(\mathrm{~s}$, $3 \mathrm{H}), 1.66-1.81(\mathrm{~m}, 3 \mathrm{H}), 1.0(\mathrm{t}, \mathrm{J}=5.4,6 \mathrm{H})$. MS (ESI) $346.2[\mathrm{M}-\mathrm{H}]^{-} . \mathrm{IR}\left(\mathrm{cm}^{-1}\right) 1646.75$ (amide), 1740.66 (ester).

\section{(S)-Methyl 4-methyl-2-(4-( $\mathrm{N}$-thiazol-2-ylsulfamoyl)benzamido)pentanoate}

(27a). 2-Aminothiazole (3.8 g, $38.0 \mathrm{mmol})$ and $\mathrm{K}_{2} \mathrm{CO}_{3}(10.5 \mathrm{~g}, 76.0 \mathrm{mmol})$ were added to a solution of $26 \mathbf{a}(8.8 \mathrm{~g}, 25.3 \mathrm{mmol})$ in dry Acetonitrile $(60 \mathrm{~mL})$ and the mixture was stirred for $8 \mathrm{~h}$ at $75^{\circ} \mathrm{C}$, filtered, and the solvent was removed in vacuo. The solid was purified by flash chromatography (acetone/hexane, $3: 2$ ) to give a white solid in $43.5 \%$ yield. m.p. 85-89 ${ }^{\circ} \mathrm{C} .{ }^{1} \mathrm{H}$ NMR $\left(\mathrm{CDCl}_{3}\right) \delta 7.897(\mathrm{dd}, \mathrm{J}=8.7,18.3,4 \mathrm{H})$, $7.174(\mathrm{~d}, \mathrm{~J}=6.0,1 \mathrm{H}), 6.864(\mathrm{~d}, \mathrm{~J}=8.4,1 \mathrm{H}), 6.581(\mathrm{~d}, \mathrm{~J}=6.0,1 \mathrm{H}), 4.814-4.887(\mathrm{~m}, 1 \mathrm{H})$, 3.785 (s, 3H), 1.683-1.806 (m, 3H), 0.993 (dd, J=3, 6, 6H). MS (ESI) 410.2[M-H]'. IR $\left(\mathrm{cm}^{-1}\right) 16385$ (amide), 1737 (ester).

(3S)-Methyl 2-hydroxy-3-((S)-4-methyl-2-(4-( $N$-thiazol-2-ylsulfamoyl) benzamido)-pentanamido)-4-phenylbutanoate (29a). A mixture of $1.0 \mathrm{~N} \mathrm{NaOH}(30$ $\mathrm{mL})$ and $\mathrm{MeOH}(10 \mathrm{~mL})$ was added to a solution of $27 \mathrm{a}(420 \mathrm{mg}, 1.02 \mathrm{mmol})$ in $\mathrm{CH}_{2} \mathrm{Cl}_{2}(50 \mathrm{~mL})$ and stirred at RT for $3 \mathrm{~h}$. The organic solvent was removed and the aqueous phase was adjusted to $\mathrm{pH} 2$ with $5.0 \mathrm{~N} \mathrm{HCl}$. The solid that separated out was recovered and used in the next step without purification. The solid $(500 \mathrm{mg}, 1.26$ mmol) was dissolved in anhydrous DMF (5 mL) and HBTU (0.45 g, $1.19 \mathrm{mmol})$ was added at $0{ }^{\circ} \mathrm{C}$. After stirring at RT for $1 \mathrm{~h}, \mathbf{2 8}^{167}(0.29 \mathrm{~g}, 1.38 \mathrm{mmol})$ and DIPEA $(0.33$ $\mathrm{mL})$ in anhydrous DMF (5 mL) was added and the mixture was stirred for $16 \mathrm{~h}$ to give a white solid in $44 \%$ yield. m.p. $202-204{ }^{\circ} \mathrm{C} .{ }^{1} \mathrm{H}$ NMR (DMSO- $\left.d_{6}\right) \delta 8.41(\mathrm{dd}$, $\mathrm{J}=8.7,12.3,1 \mathrm{H}), 7.76-7.90(\mathrm{~m}, 4 \mathrm{H}), 7.13-7.20(\mathrm{~m}, 5 \mathrm{H}), 6.99(\mathrm{~d}, \mathrm{~J}=3.9,1 \mathrm{H}), 6.53(\mathrm{~d}$, $\mathrm{J}=3.9,1 \mathrm{H}), 4.38-4.46(\mathrm{~m}, 1 \mathrm{H}), 4.22-4.30(\mathrm{~m}, 1 \mathrm{H}), 3.99-4.08(\mathrm{~m}, 1 \mathrm{H}), 3.49(\mathrm{~d}$, $\mathrm{J}=4.8,3 \mathrm{H}), 2.86(\mathrm{dd}, \mathrm{J}=6.0,13.2,1 \mathrm{H}), 2.68(\mathrm{dd}, \mathrm{J}=9.0,13.2,1 \mathrm{H}), 1.38-1.54(\mathrm{~m}, 2 \mathrm{H})$, 1.28-1.34 (m, 1H), 0.79-0.90 (m, 6H). MS (ESI) 587.2 [M-H]-. IR $\left(\mathrm{cm}^{-1}\right)$ 1647.55(amide), 1737.95 (ester), $3306.25(\mathrm{NH}$ and $\mathrm{OH})$.

(S)-Methyl 3-((S)-4-methyl-2-(4-( $N$-thiazol-2-ylsulfamoyl)benzamido) pentanamido)-2-oxo-4-phenylbutanoate (13). Dess-Martin oxidation (general procedure 3 ) of 29a (350 $\mathrm{mg}, 0.59 \mathrm{mmol}$ ) followed by flash chromatographic (acetone/hexane, 1:1) purification gave $\mathbf{1 3}$ as a white solid in 53.3\% yield. m.p. 118-122 ${ }^{\circ} \mathrm{C} .{ }^{1} \mathrm{H}$ NMR $\left(\mathrm{CDCl}_{3}\right) \delta 12.50(\mathrm{~s}, 1 \mathrm{H}), 7.70-7.78(\mathrm{~m}, 4 \mathrm{H}), 7.52(\mathrm{~d}, \mathrm{~J}=8.4,1 \mathrm{H})$, 7.06-7.38 (m, 6H), $6.58(\mathrm{dd}, \mathrm{J}=0.9,4.5,1 \mathrm{H}), 5.26-5.36(\mathrm{~m}, 1 \mathrm{H}), 4.72(\mathrm{dd}, \mathrm{J}=8.4,14.1$, $1 \mathrm{H}), 3.79(\mathrm{~d}, \mathrm{~J}=3.3,3 \mathrm{H}), 3.26(\mathrm{dt}, \mathrm{J}=5.7,13.8,1 \mathrm{H}), 3.00(\mathrm{dt}, \mathrm{J}=8.7,14.1,1 \mathrm{H})$, 1.45-1.74 (m,3H), 0.83-0.94 (m, 6H). MS (ESI) 585.0 [M-H]-. IR (cm-1) 1632 (amide and $\alpha$-ketone), 1732 (ester), $3298(\mathrm{NH})$. Anal. Calcd. for: $\mathrm{C}_{27} \mathrm{H}_{30} \mathrm{~N}_{4} \mathrm{O}_{7} \mathrm{~S}_{2}, \mathrm{C}, 55.28 ; \mathrm{H}$, 5.15; N, 9.55; S, 10.93. Found: C, 55.08; H, 5.41; N, 9.36; S, 10.64.

(S)-Methyl 4-methyl-2-(3-( $N$-thiazol-2-ylsulfamoyl)benzamido)pentanoate (27b). $\mathrm{SOCl}_{2}(30 \mathrm{~mL})$ was added to an ice-cooled solution of 3-chlorosulfonyl 
benzoic acid $(7.0 \mathrm{~g}, 31.7 \mathrm{mmol})$ in 1,2-dichloroethane $(14 \mathrm{~mL})$ at $0{ }^{\circ} \mathrm{C}$. The mixture was allowed to warm to RT and then refluxed for $2 \mathrm{~h}$. The solvent was removed in vacuo to give a light-brown liquid, which was dissolved in anhydrous $\mathrm{CH}_{2} \mathrm{Cl}_{2}(30 \mathrm{~mL})$ and L-leucine methylester hydrochloride ( $8.64 \mathrm{~g}, 47.59 \mathrm{mmol}$ ) in anhydrous $\mathrm{CH}_{2} \mathrm{Cl}_{2}$ $(30 \mathrm{~mL})$ containing DIEA $(8 \mathrm{~mL})$ was added at $-20^{\circ} \mathrm{C}$. The mixture was stirred for 30 min. at $-15^{\circ} \mathrm{C}$ to $0{ }^{\circ} \mathrm{C}$ and then at $\mathrm{RT}$ for $1.5 \mathrm{~h}$. The solvent was removed to give an oil $(91.8 \%)$, which was used in the next step without purification. The oil (6.8 g, 19.6 mmol) was added to a solution of 2-aminothiazole (1.96 g, $19.6 \mathrm{mmol})$ in $\mathrm{CH}_{2} \mathrm{Cl}_{2}(50$ $\mathrm{mL})$ containing anhydrous pyridine $(35 \mathrm{~mL})$. The mixture was heated at $40{ }^{\circ} \mathrm{C}$ for 58 $\mathrm{h}$ and the solvent was removed in vacuo. The resulting gummy solid was dissolved in EtOAc containing $2 \mathrm{~N} \mathrm{HCl}$. The organic phase was separated, washed with $0.5 \mathrm{~N} \mathrm{HCl}$, brine, and dried $\left(\mathrm{MgSO}_{4}\right)$. The solvent was evaporated and the residue was purified by column chromatography (acetone/hexane, 4:3) to give colorless oil in $44.4 \%$ yield. ${ }^{1} \mathrm{H} \mathrm{NMR}\left(\mathrm{CDCl}_{3}\right) \delta 8.27(\mathrm{~s}, 1 \mathrm{H}), 7.88(\mathrm{~d}, \mathrm{~J}=7.8,2 \mathrm{H}), 7.44(\mathrm{~d}, \mathrm{~J}=7.8,1 \mathrm{H}), 7.37(\mathrm{t}$, $\mathrm{J}=8.4,1 \mathrm{H}), 7.04(\mathrm{~d}, \mathrm{~J}=4.8,1 \mathrm{H}), 6.49(\mathrm{~d}, \mathrm{~J}=4.8,1 \mathrm{H}), 4.72-4.75(\mathrm{~m}, 1 \mathrm{H}), 3.66(\mathrm{~s}, 3 \mathrm{H})$, 1.64-1.66 (m, 3H), $0.86(\mathrm{~d}, \mathrm{~J}=5.7,6 \mathrm{H})$. MS (ESI) $410.0[\mathrm{M}-\mathrm{H}]^{-} . \mathrm{IR}\left(\mathrm{cm}^{-1}\right) 3298(\mathrm{NH})$, $1744(\mathrm{C}=\mathrm{O})$.

(3S)-Methyl 2-hydroxy-3-((S)-4-methyl-2-(3-( $N$-thiazol-2-ylsulfamoyl) benzamido)-pentanamido)-4-phenylbutanoate (29b). $\mathrm{NaOH}(2.0 \mathrm{~N}, 75 \mathrm{~mL})$ was added to a solution of $27 \mathbf{b}(3.4 \mathrm{~g}, 8.27 \mathrm{mmol})$ in $\mathrm{MeOH}(150 \mathrm{~mL})$ and the mixture was stirred at RT for $1.5 \mathrm{~h}$. The $\mathrm{MeOH}$ was removed and the aqueous phase was adjusted to $\mathrm{pH} 2$ with $5.0 \mathrm{~N} \mathrm{HCl}$ to give a light yellow solid (3.0 g), which was used without purification. Mukayaima's reagent $(1.79 \mathrm{~g}, 7.0 \mathrm{mmol})$ in anhydrous DMF (8 $\mathrm{mL})$ was added into a stirred ice-cooled solution of above solid $(2.54 \mathrm{~g}, 6.4 \mathrm{mmol})$, $\mathbf{2 8}^{167}(1.21 \mathrm{~g}, 5.8 \mathrm{mmol})$ and TEA $(2 \mathrm{~mL})$ in anhydrous DMF $(11 \mathrm{~mL})$. After stirring at RT for $36 \mathrm{~h}$, the solution was poured into $\mathrm{H}_{2} \mathrm{O}(200 \mathrm{~mL})$ and the white solid that separated out was recovered by filtration and the filtrate was extracted with EtOAc (3 x $25 \mathrm{~mL}$ ). Evaporation of the solvent gave more solid and the combined solids were purified by column chromatography $\left(\mathrm{CH}_{2} \mathrm{Cl}_{2} / \mathrm{MeOH}, 20: 1\right)$ to give a white solid in $31.9 \%$ yield. ${ }^{1} \mathrm{H}$ NMR (acetone- $\left.d_{6}\right) \delta 8.39(\mathrm{t}, \mathrm{J}=1.5,1 \mathrm{H}), 8.09(\mathrm{dt}, \mathrm{J}=1.5,7.8,1 \mathrm{H})$, 8.01-8.04 (m, 2H), $7.608(\mathrm{t}, \mathrm{J}=7.8,1 \mathrm{H}), 7.08-7.36(\mathrm{~m}, 6 \mathrm{H}), 0.79(\mathrm{~d}, \mathrm{~J}=4.5,1 \mathrm{H})$, 4.61-4.68 (m, 1H), 4.42-4.51 (m, 1H), $4.15(\mathrm{~d}, \mathrm{~J}=2.4,1 \mathrm{H}), 3.56-3.64(\mathrm{~m}, 3 \mathrm{H})$, 1.55-1.73 (m, 3H), 0.82-0.99 (m, 6H). MS (ESI) 587.0 [M-H] $]^{-}$IR $\left(\mathrm{cm}^{-1}\right) 3317(\mathrm{NH}$, $\mathrm{OH}), 1736$ and $1639(\mathrm{C}=\mathrm{O})$.

\section{$N$-((2S)-1-((2S)-4-Amino-3-hydroxy-4-oxo-1-phenylbutan-2-ylamino)-4-} methyl-1-oxopentan-2-yl)-3-( $N$-thiazol-2-ylsulfamoyl)benzamide (30). Compound 29b (700 mg, $1.19 \mathrm{mmol}$ ) was dissolved in $7.0 \mathrm{~N}$ methanolic ammonia (35 mL) and stirred at RT for $48 \mathrm{~h}$ following which the solvent was removed and the product was purified by column chromatography (acetone/hexane/MeOH, 6:2:1) to give a white solid in 69.6\% yield. m.p. $151-157{ }^{\circ} \mathrm{C} .{ }^{1} \mathrm{H}$ NMR (DMSO- $\left.d_{6}\right) \delta 8.68-8.74(\mathrm{~m}, 1 \mathrm{H})$, $8.30(\mathrm{t}, \mathrm{J}=1.5,1 \mathrm{H}), 8.08(\mathrm{~d}, \mathrm{~J}=7.8,1 \mathrm{H}), 8.95(\mathrm{dt}, \mathrm{J}=7.8,0.9,1 \mathrm{H}), 7.57-7.71(\mathrm{~m}, 2 \mathrm{H})$, 7.02-7.25 (m, 8H), $6.08(\mathrm{~d}, \mathrm{~J}=4.5,1 \mathrm{H}), 5.95$ and $5.78(\mathrm{~s}, 2: 1,1 \mathrm{H}), 4.41-4.53(\mathrm{~m}, 1 \mathrm{H})$, 
4.17-4.25 (m,1H), 3.83 and $3.75(\mathrm{~s}, 1: 2,1 \mathrm{H}), 2.80-2.88(\mathrm{~m}, 1 \mathrm{H}), 2.58-2.68(\mathrm{~m}, 1 \mathrm{H})$, 1.34-1.64 (m, 3H), 0.81-0.96 (m, 6H). MS (ESI) 572.1 [M-H]. IR ( $\left.\mathrm{cm}^{-1}\right) 3298(\mathrm{OH}$ and $\mathrm{NH}), 1645(\mathrm{C}=\mathrm{O})$.

\section{$N$-((S)-1-((S)-4-Amino-3,4-dioxo-1-phenylbutan-2-ylamino)-4-methyl-1-} oxopentan-2-yl)-3-( $N$-thiazol-2-ylsulfamoyl)benzamide (14). Oxidation of 30 (425 $\mathrm{mg}, 0.742 \mathrm{mmol}$ ) with pyridine-sulfur trioxide complex as described under general procedure 4 followed by flash chromatographic purification (acetone/hexane, 3:2) of the crude product gave 14 as a white solid in $54.9 \%$ yield. m.p $228-231{ }^{\circ} \mathrm{C}$. ${ }^{1} \mathrm{H}$ NMR $\left(\mathrm{DMSO}_{-} \mathrm{d}_{6}\right) \delta 12.80(\mathrm{~s}, 1 \mathrm{H}), 8.72(\mathrm{~d}, \mathrm{~J}=8.4,1 \mathrm{H}), 8.29-8.35(\mathrm{~m}, 2 \mathrm{H}), 8.06(\mathrm{t}, \mathrm{J}=7.8$, 2H), $7.95(\mathrm{~d}, \mathrm{~J}=8.1,1 \mathrm{H}), 7.79(\mathrm{~s}, 1 \mathrm{H}), 7.63(\mathrm{t}, \mathrm{J}=7.8,1 \mathrm{H}), 7.12-7.27(\mathrm{~m}, 6 \mathrm{H}), 6.85(\mathrm{dd}$, $\mathrm{J}=1.5,4.5,1 \mathrm{H}), 5.18-5.25(\mathrm{~m}, 1 \mathrm{H}), 4.53-4.60(\mathrm{~m}, 1 \mathrm{H}), 3.11(\mathrm{dd}, \mathrm{J}=4.2,14.4,1 \mathrm{H}), 2.83$ $(\mathrm{dd}, \mathrm{J}=9.3,14.4,1 \mathrm{H}), 1.49-1.67$ (m, 3H), 0.80-0.91 (m, 6H). MS (ESI) 570.0 [M-H] . IR $\left(\mathrm{cm}^{-1}\right) 3426$ and $3276(\mathrm{NH}), 1731,1674$ and $1637(\mathrm{C}=\mathrm{O})$. Anal. Calcd. for: $\mathrm{C}_{26} \mathrm{H}_{29} \mathrm{~N}_{5} \mathrm{O}_{6} \mathrm{~S}_{2}, \mathrm{C}, 54.63 ; \mathrm{H}, 5.16 ; \mathrm{N}, 12.02 ; \mathrm{S}, 11.22$. Found: C, 54.27; H, 5.16; N, $12.02 ; \mathrm{S}, 10.99$

\subsubsection{Synthesis of Compounds 15-17}

(S)-3-Methyl-2-(4-(phenyldiazenyl)phenylsulfonamido)butanoic acid (32). 4-Phenyl azobenzenesulfonyl chloride (3 g, $10.69 \mathrm{mmol}$ ) was added to a stirred ice-cooled solution of $\mathrm{L}-\mathrm{H}-\mathrm{Val}-\mathrm{OMe} \cdot \mathrm{HCl}(2.15 \mathrm{~g}, 12.8 \mathrm{mmol})$ in anhydrous pyridine $(15 \mathrm{~mL})$ and the resulting crimson solution was stirred at RT for $44 \mathrm{~h}$. Following this the mixture was poured into $2.0 \mathrm{~N} \mathrm{HCl}(100 \mathrm{~mL})$ and extracted with EtOAc $(2 \times 60$ $\mathrm{mL}$ ). The extract was washed successively with $1.0 \mathrm{~N} \mathrm{HCl}$, saturated $\mathrm{NaHCO}_{3}$, brine, dried $\left(\mathrm{MgSO}_{4}\right)$, and concentrated. The residue was purified by column chromatography (EtOAc/hexane, 1:2) to give (S)-Methyl-3-methyl-2-(4-(phenyldiazenyl)phenyl-sulfonamido)butanoate as an orange solid in $92.5 \%$ yield. m.p. $150-152{ }^{\circ} \mathrm{C} .{ }^{1} \mathrm{H} \mathrm{NMR}\left(\mathrm{CDCl}_{3}\right) \delta 7.94-8.03(\mathrm{~m}, 6 \mathrm{H})$, 7.53-7.60 (m, 3H), $5.18(\mathrm{~d}, \mathrm{~J}=9.9,1 \mathrm{H}), 3.83\left(\mathrm{dd}, \mathrm{J}_{1}=10.2,5.1,1 \mathrm{H}\right), 3.47(\mathrm{~s}, 3 \mathrm{H})$, 2.04-2.11 (m, 1H), 0.99 (d, J=6.9, 3H), 0.90 (d, J=6.9, 3H). MS (ESI) 374.0 [M-H]', $398[\mathrm{M}+\mathrm{Na}]^{+}$. IR $\left(\mathrm{cm}^{-1}\right) 1736$ (ester), 3282 (amide). $\mathrm{NaOH}(1.0 \mathrm{~N}, 100 \mathrm{~mL}$ ) was added to a solution of the orange solid $(3.3 \mathrm{~g}, 8.8 \mathrm{mmol})$ in $\mathrm{MeOH}(50 \mathrm{~mL})$ and the mixture was stirred at $55^{\circ} \mathrm{C}$ for $4 \mathrm{~h}$ after which the $\mathrm{pH}$ was adjusted to 2 with $2.0 \mathrm{~N}$ $\mathrm{HCl}$. The solvent was removed and the crude product was recrystallized from $\mathrm{CH}_{2} \mathrm{Cl}_{2}$ /ethyl acetate to give 32 as a yellow solid in $75.5 \%$ yield. m.p. $220-222{ }^{\circ} \mathrm{C} .{ }^{1} \mathrm{H}$ NMR $\left(\mathrm{CDCl}_{3}\right) \delta$ 7.95-8.00 (m, 6H), 7.54-7.59 (3H), $5.17(\mathrm{~d}, \mathrm{~J}=10.2,1 \mathrm{H}), 3.87(\mathrm{dd}$, $\mathrm{J}=4.5,9.9,1 \mathrm{H}), 2.41(\mathrm{br}, 1 \mathrm{H}, \mathrm{COOH}), 2.07-2.18(\mathrm{~m}, 1 \mathrm{H}), 0.99(\mathrm{~d}, \mathrm{~J}=6.6,3 \mathrm{H}), 0.88(\mathrm{~d}$, $\mathrm{J}=6.6,3 \mathrm{H})$. MS (ESI) $360.0[\mathrm{M}-\mathrm{H}]^{-}, 384.1[\mathrm{M}+\mathrm{Na}]^{+}$. IR $\left(\mathrm{cm}^{-1}\right) 1694(\mathrm{C}=\mathrm{O}), 2876(\mathrm{br}$, $\mathrm{COOH}), 3294$ (amide).

(S)-3-Methyl- $N$-((S)-4-methyl-1-oxopentan-2-yl)-2-(4-(phenyldiazenyl)phenylsulfonamido)-butanamide (15). CDI (494 mg, $3.05 \mathrm{mmol}$ ) was added to a stirred 
ice-cooled solution of $32(1.0 \mathrm{~g}, 2.77 \mathrm{mmol})$ in a mixture of THF $(15 \mathrm{~mL})$ and $\mathrm{CH}_{2} \mathrm{Cl}_{2}$ $(20 \mathrm{~mL})$. Stirring was continued at RT for $30 \mathrm{~min}$. and L-leucinol $(531 \mu \mathrm{L}, 4.16 \mathrm{mmol})$ was added and the mixture was stirred at RT for $96 \mathrm{~h}$. The solvent was removed and the residue was recrystallized from acetone $/ \mathrm{CH}_{2} \mathrm{Cl}_{2}$ mixture to give (S)- $N$-((S)-1-hydroxy-4-methylpentan-2-yl)-3-methyl-2-(4-(phenyldiazenyl)-phenyl-s ulfonamido)butanamide as a yellow solid in $51.0 \%$ yield. m.p.237-238 ${ }^{\circ} \mathrm{C} .{ }^{1} \mathrm{H}$ NMR (acetone- $\left.d_{6}\right) \delta$ 7.98-8.08 (m, 6H), 7.62-7.68 (m, 3H), $6.98(\mathrm{~d}, \mathrm{~J}=8.1,1 \mathrm{H}), 6.52(\mathrm{~d}$, $\mathrm{J}=8.7,1 \mathrm{H}), 3.69-3.81(\mathrm{~m}, 3 \mathrm{H}), 3.36-3.42(\mathrm{~m}, 2 \mathrm{H}), 2.00-2.06(\mathrm{~m}, 1 \mathrm{H}), 1.10-1.19(\mathrm{~m}$, $3 \mathrm{H}), 1.00(\mathrm{~d}, \mathrm{~J}=6.9,3 \mathrm{H}), 0.89(\mathrm{~d}, \mathrm{~J}=6.9,3 \mathrm{H}), 0.69(\mathrm{~d}, \mathrm{~J}=6.0,3 \mathrm{H}), 0.64(\mathrm{~d}, \mathrm{~J}=6.0,3 \mathrm{H})$. MS (ESI) $459.0[\mathrm{M}-\mathrm{H}]^{-}, 483.3[\mathrm{M}+\mathrm{Na}]^{+}$. IR $\left(\mathrm{cm}^{-1}\right) 1639(\mathrm{C}=\mathrm{O}), 3284$ (amide), 3505 (amide). Dess-Martin oxidation (general procedure 3 ) of the yellow solid (300 $\mathrm{mg}$, $0.65 \mathrm{mmol}$ ) followed by flash chromatographic purification (acetone $/ \mathrm{CH}_{2} \mathrm{Cl}_{2} /$ hexane, 2:1:4) gave 15 in 50.2\% yield. m.p. $146-149{ }^{\circ} \mathrm{C} .{ }^{1} \mathrm{H}$ NMR (acetone- $d_{6}$ ) $\delta 9.50$ and $9.42(\mathrm{~s}, 2: 1,1 \mathrm{H})), 7.94-8.10(\mathrm{~m}, 6 \mathrm{H}), 7.54-7.63(\mathrm{~m}, 3 \mathrm{H}), 6.30$ and $6.01(\mathrm{~d}, 1: 2, \mathrm{~J}=7.2$ and $7.8,1 \mathrm{H}), 5.45$ and $5.26(\mathrm{~d}, 2: 1, \mathrm{~J}=8.7$ and $8.1,1 \mathrm{H}), 4.40-4.48(\mathrm{~m}, 1 \mathrm{H}), 3.63-3.70$ (m, 1H), 2.09-2.20 (m, 1H), 1.19-1.70 (m, 3H), 0.79-1.01 (m, 12H). MS (ESI) 457.0 [M-H] $, 513.3[\mathrm{M}+\mathrm{Na}+\mathrm{MeOH}]^{+} . \mathrm{IR}\left(\mathrm{cm}^{-1}\right) 1715(\mathrm{CHO}), 1668(\mathrm{C}=\mathrm{O})$. Anal. Calcd. for: $\mathrm{C}_{23} \mathrm{H}_{30} \mathrm{~N}_{4} \mathrm{O}_{4} \mathrm{~S}, \mathrm{C}, 60.24 ; \mathrm{H}, 6.59 ; \mathrm{N}, 12.22 ; \mathrm{S}, 6.99$. Found: C, 60.05; H, 6.66; N, $12.17 ; \mathrm{S}, 6.83$.

(2S)-N-((2S)-1-Cyano-1-hydroxy-4-methylpentan-2-yl)-3-methyl-2-(4(phenyldiazenyl)-phenylsulfonamido)butanamide (34). $\mathrm{NaHSO}_{3}(3.2 \%, 11 \mathrm{~mL})$ was added to a solution of $\mathbf{1 5}(847 \mathrm{mg}, 1.85 \mathrm{mmol})$ in $\mathrm{MeOH}(30 \mathrm{~mL})$ and stirred at RT for $30 \mathrm{~h}$. EtOAc $(25 \mathrm{~mL})$ was added followed by $3.2 \% \mathrm{KCN}$ solution and stirring was continued for another $5 \mathrm{~h}$. The EtOAc layer was separated and the aqueous layer was extracted twice with EtOAc. The combined organic layer was washed with water, brine, and dried $\left(\mathrm{MgSO}_{4}\right)$. The solvent was removed in vacuo to give an orange solid in $90 \%$ yield. m.p $93-98{ }^{\circ} \mathrm{C} .{ }^{1} \mathrm{H}$ NMR $(\mathrm{CDCl} 3) \delta$ 7.96-8.04 (m, 6H), 7.56-7.63 (m, $3 \mathrm{H}), 6.40-6.53(\mathrm{~m}, 1 \mathrm{H}), 5.43-5.52(\mathrm{~m}, 1 \mathrm{H}), 4.50-4.57(\mathrm{~m}, 1 \mathrm{H}), 4.08-4.24(\mathrm{~m}, 1 \mathrm{H})$, 3.55-3.66 (m, 1H), 2.12-2.24 (m, 1H), 1.40- $1.58(\mathrm{~m}, 3 \mathrm{H}), 0.74-1.00(\mathrm{~m}, 12 \mathrm{H})$. MS (ESI) $508.1[\mathrm{M}+\mathrm{H}]^{+}$. IR $\left(\mathrm{cm}^{-1}\right) 3322(\mathrm{OH}), 1659(\mathrm{C}=\mathrm{O})$

\section{(3S)-Methyl-2-hydroxy-5-methyl-3-((S)-3-methyl-2-(4-(phenyldiazenyl)} phenylsulfonamido)-butanamido)hexanoate (35). Conc. $\mathrm{HCl}(15 \mathrm{~mL})$ was added to a solution of $34(810 \mathrm{mg}, 1.67 \mathrm{mmol})$ in $\mathrm{MeOH}(20 \mathrm{~mL})$ and the mixture was stirred at $62{ }^{\circ} \mathrm{C}$ for $24 \mathrm{~h}$ followed by concentration in vacuo and purification by column chromatography (EtOAc/hexane, 1:1) to give an orange solid in $69.4 \%$ yield. m.p 163-168 ${ }^{\circ} \mathrm{C} .{ }^{1} \mathrm{H}$ NMR $\left(\mathrm{CDCl}_{3}\right)$ 8 7.95-8.02 (m, 6H), 7.55-7.57 (m, 3H), $5.96(\mathrm{~d}, \mathrm{~J}=9.0$, $1 \mathrm{H}), 5.57(\mathrm{~d}, \mathrm{~J}=7.8,1 \mathrm{H}), 4.22-4.33(\mathrm{~m}, 2 \mathrm{H}), 3.80(\mathrm{~s}, 3 \mathrm{H}), 3.59(\mathrm{dd}, \mathrm{J}=4.8,7.8,1 \mathrm{H})$, 2.07-2.15 (m, 1H), 1.04-1.41 (m, 3H), 0.68-0.98 (m, 12H). MS (ESI) 517.0 [M-H]', $541.2[\mathrm{M}+\mathrm{Na}]^{+} . \mathrm{IR}\left(\mathrm{cm}^{-1}\right) 3522,3355$ and $3270(\mathrm{NH}$ and $\mathrm{OH}), 1737$ and $1648(\mathrm{C}=\mathrm{O})$.

(3S)-2-Hydroxy-5-methyl-3-((S)-3-methyl-2-(4-(phenyldiazenyl)phenylsulfonamido)-butanamido)hexanamide (36). Compound 35 (600 mg, $1.15 \mathrm{mmol}$ ) was 
dissolved in 7.0 N methanolic ammonia $(30 \mathrm{~mL})$ and stirred at RT for $48 \mathrm{~h}$ following which the solvent was removed and the product was purified by column chromatography (ethyl acetate/hexane, $2: 1$ ) to give an orange solid in $68.8 \%$ yield. m.p 243-248 ${ }^{\circ} \mathrm{C} .{ }^{1} \mathrm{H}$ NMR (DMSO-d 6 ) $\delta$ 7.39-8.06 (m, 11H), 7.03-7.14 (m, 2H), 5.52 $(\mathrm{dd}, \mathrm{J}=5.7,15.3,1 \mathrm{H}), 3.93-3.96(\mathrm{~m}, 1 \mathrm{H}), 3.64-3.74(\mathrm{~m}, 2 \mathrm{H}), 1.85-1.92(\mathrm{~m}, 1 \mathrm{H})$, 1.23-1.26 (m, 1H), 0.70-1.11 (m, 8H), 0.43-0.63 (m, 6H). MS (ESI) 501.9 [M-H]', $526.2[\mathrm{M}+\mathrm{Na}]^{+}$. IR $\left(\mathrm{cm}^{-1}\right) 3454,3357$ and $3322(\mathrm{NH}$ and $\mathrm{OH}), 1668$ and $1644(\mathrm{C}=\mathrm{O})$.

(1S)- $N$-((S)-1-Amino-5-methyl-1,2-dioxohexan-3-yl)-2-(4-(phenyldiazenyl) phenylsulfonyl)-cyclopentane carboxamide (17). Oxidation of 36 (350 mg, 0.696 mmol) with pyridine-sulfur trioxide complex as described under general procedure 4 followed by column chromatographic purification (acetone/hexane 1:1) gave $\mathbf{1 7}$ as an orange solid in $71.7 \%$ yield. m.p. $134-136{ }^{\circ} \mathrm{C} .{ }^{1} \mathrm{H}$ NMR (acetone- $\left.d_{6}\right) \delta 7.97-8.09(\mathrm{~m}$, $6 \mathrm{H}), 7.61-7.68(\mathrm{~m}, 2 \mathrm{H}), 7.46(\mathrm{~d}, \mathrm{~J}=6.9,2 \mathrm{H}), 6.99(\mathrm{~s}, 1 \mathrm{H}), 6.56(\mathrm{~d}, \mathrm{~J}=9.3,1 \mathrm{H})$, 5.03-5.10 (m, 1H), 1.19-1.52 (m, 3H), $1.00(\mathrm{~d}, \mathrm{~J}=6.9,3 \mathrm{H}), 0.89(\mathrm{~d}, \mathrm{~J}=6.9,3 \mathrm{H}), 0.73$ $(\mathrm{dd}, \mathrm{J}=6.3,9.3,6 \mathrm{H})$. MS (ESI) $500.6[\mathrm{M}-\mathrm{H}]^{-} . \mathrm{IR}\left(\mathrm{cm}^{-1}\right) 3464,3360$ and $3281(\mathrm{NH})$, $1736(\mathrm{C}=\mathrm{O}), 1693(\mathrm{C}=\mathrm{O})$. Anal. Calcd. for: $\mathrm{C}_{24} \mathrm{H}_{31} \mathrm{~N}_{5} \mathrm{O}_{5} \mathrm{~S} \bullet 0.5 \mathrm{H}_{2} \mathrm{O}, \mathrm{C}, 56.45 ; \mathrm{H}, 6.32$; N, 13.72; S, 6.28. Found: C, 56.30; H, 6.09; N, 13.59; S, 6.16.

(1S)-2-(4-(Phenyldiazenyl)phenylsulfonyl)cyclopentanecarboxylic acid (33). 4-Phenyl azobenzenesulfonyl chloride (5 g, $17.8 \mathrm{mmol}$ ) was added to an ice-cooled solution of D-Pro-OMe $\cdot \mathrm{HCl}(3.54 \mathrm{~g}, 21.3 \mathrm{mmol})$ in anhydrous pyridine $(25 \mathrm{~mL})$ and stirred for $20 \mathrm{~h}$ at RT after which the mixture was poured into $2.0 \mathrm{~N} \mathrm{HCl}(50 \mathrm{~mL})$ solution and extracted with EtOAc $(2 \times 40 \mathrm{~mL})$. The EtOAc extract was washed successively with $2.0 \mathrm{~N} \mathrm{HCl}$, saturated $\mathrm{NaHCO}_{3}$, brine, dried $\left(\mathrm{MgSO}_{4}\right)$, and concentrated. The residue was purified by column chromatography (acetone/hexane, 1:2) to give (1S)-methyl-2-(4-(phenyldiazenyl)phenylsulfonyl)

cyclopentane carboxylate as a yellow solid in $87.3 \%$ yield. m.p. $126-128{ }^{\circ} \mathrm{C} .{ }^{1} \mathrm{H}$ NMR $\left(\mathrm{CDCl}_{3}\right) \delta 8.04(\mathrm{~s}, 4 \mathrm{H}), 7.95-7.98(\mathrm{~m}, 2 \mathrm{H}), 7.53-7.60(\mathrm{~m}, 3 \mathrm{H}), 4.40(\mathrm{dd}, \mathrm{J}=5.6,6.9$, $1 \mathrm{H}), 3.73(\mathrm{~s}, 3 \mathrm{H}), 3.52-3.58(\mathrm{~m}, 1 \mathrm{H}), 3.39-3.45(\mathrm{~m}, 1 \mathrm{H}), 1.98-2.12(\mathrm{~m}, 3 \mathrm{H}), 1.84-1.87$ (m, 1H). MS (ESI) $396.1[\mathrm{M}+\mathrm{Na}]^{+}$. IR $\left(\mathrm{cm}^{-1}\right) 1743(\mathrm{C}=\mathrm{O})$. The yellow solid $(1.5 \mathrm{~g}, 4$ mmol) was dissolved in $\mathrm{MeOH}(50 \mathrm{~mL})$ and $1.0 \mathrm{~N} \mathrm{NaOH}(90 \mathrm{~mL})$ was added and the mixture was stirred at RT for $16 \mathrm{~h}$ followed by $2 \mathrm{~h}$ of refluxing. The mixture was adjusted to $\mathrm{pH} 2$ with $2.0 \mathrm{~N} \mathrm{HCl}$ and extracted with EtOAc. The extract was washed with brine, dried $\left(\mathrm{MgSO}_{4}\right)$, concentrated and purified by recrystallization from $\mathrm{CH}_{2} \mathrm{Cl}_{2} /$ hexane to give 33 as an orange solid in $87.3 \%$ yield. m.p. $174-177^{\circ} \mathrm{C} .{ }^{1} \mathrm{H}$ $\operatorname{NMR}\left(\mathrm{CDCl}_{3}\right) \delta 8.05(\mathrm{~s}, 4 \mathrm{H}), 7.96-7.99(\mathrm{~m}, 2 \mathrm{H}), 7.55-7.57(\mathrm{~m}, 3 \mathrm{H}), 4.63(\mathrm{br}, 1 \mathrm{H})$, $3.58(\mathrm{~s}, 1 \mathrm{H}), 3.35-3.40(\mathrm{~m}, 1 \mathrm{H}), 1.83-2.18(\mathrm{~m}, 4 \mathrm{H})$. MS (ESI) $358.0[\mathrm{M}-\mathrm{H}]^{-}$. IR $\left(\mathrm{cm}^{-1}\right)$ 1730 (acid), 2883 (br, $\mathrm{COOH}$ ).

(1S)- $N$-((S)-4-Methyl-1-oxopentan-2-yl)-2-(4-(phenyldiazenyl)phenylsulfonyl)cyclopentane-carboxamide (16). CDI (474 mg, $2.93 \mathrm{mmol}$ ) was added to an ice-cooled solution of $33(955 \mathrm{~g}, 2.66 \mathrm{mmol})$ in a mixture of THF $(20 \mathrm{~mL})$ and $\mathrm{CH}_{2} \mathrm{Cl}_{2}(15 \mathrm{~mL})$ and stirred for $30 \mathrm{~min}$. at RT. L-Leucinol was added and the mixture 
was stirred at RT for $70 \mathrm{~h}$ after which the solvent was removed and the residue was recrystallized from $\mathrm{CH}_{2} \mathrm{Cl}_{2}$ /hexane to give (1S)- $N-((S)$-1-hydroxy-4methylpentan-2-yl)-2-(4-(phenyldiazenyl)phenylsulfonyl)cyclopentane carboxamide as orange solid in $60.0 \%$ yield. m.p. $152-154{ }^{\circ} \mathrm{C} .{ }^{1} \mathrm{H}$ NMR $\left(\mathrm{CDCl}_{3}\right) \delta 7.97-8.10(\mathrm{~m}$, $6 \mathrm{H}), 7.55-7.59(\mathrm{~m}, 3 \mathrm{H}), 6.75(\mathrm{~d}, \mathrm{~J}=9.0,1 \mathrm{H}), 4.08-4.16(\mathrm{~m}, 1 \mathrm{H}), 4.03(\mathrm{dd}, \mathrm{J}=3.6,8.4$, $1 \mathrm{H}), 3.81(\mathrm{dd}, \mathrm{J}=3.6,11.4,1 \mathrm{H}), 3.67-3.73(\mathrm{~m}, 1 \mathrm{H}), 3.55(\mathrm{dd}, \mathrm{J}=5.4,11.4,1 \mathrm{H})$, 3.21-3.29 (m, 1H), 1.65-1.88 (m, 5H), 1.39-1.65 (m, 2H), 0.97 (t, J=6.3, 6H). MS (ESI) $481.2[\mathrm{M}+\mathrm{Na}]^{+}$. IR $\left(\mathrm{cm}^{-1}\right) 1636(\mathrm{C}=\mathrm{O}), 3376$ (amide). Dess-Martin oxidation (general procedure 3 ) of the orange solid $(557 \mathrm{mg}, 1.21 \mathrm{mmol}$ ) followed by column chromatographic purification (ethyl acetate/hexane, 2:1) of the crude product gave 16 as yellow solid in 50.4\% yield. m.p. $79-82{ }^{\circ} \mathrm{C} .{ }^{1} \mathrm{H} \mathrm{NMR}\left(\mathrm{CDCl}_{3}\right) \delta 9.63(\mathrm{~s}, 1 \mathrm{H})$, 7.98-8.13 (m, 6H), 7.57-7.60 (m, 3H), $7.26(\mathrm{~s}, 1 \mathrm{H}), 4.43-4.50(\mathrm{~m}, 1 \mathrm{H}), 4.22-4.25(\mathrm{~m}$, $1 \mathrm{H}), 3.61-3.68(\mathrm{~m}, 1 \mathrm{H}), 3.25-3.34(\mathrm{~m}, 1 \mathrm{H}), 2.24-2.30(\mathrm{~m}, 1 \mathrm{H}), 2.24-2.30(\mathrm{~m}, 1 \mathrm{H})$, $1.66-1.86(\mathrm{~m}, 6 \mathrm{H}), 1.01(\mathrm{dd}, \mathrm{J}=6.0,8.1,6 \mathrm{H}) . \mathrm{MS}(\mathrm{ESI}) 511.3[\mathrm{M}+\mathrm{MeOH}+\mathrm{Na}]^{+}$. $\mathrm{IR}\left(\mathrm{cm}^{-1}\right) 1655(\mathrm{C}=\mathrm{O}), 1735(\mathrm{CHO}), 3366$ (amide). Anal. Calcd. for:

$\mathrm{C}_{23} \mathrm{H}_{28} \mathrm{~N}_{4} \mathrm{O}_{4} \mathrm{~S} \bullet 0.5 \mathrm{H}_{2} \mathrm{O}, \mathrm{C}, 59.34 ; \mathrm{H}, 6.28 ; \mathrm{N}, 12.03$; S, 6.89. Found: C, 59.28; H, 6.16; N, 11.96; S, 6.69.

\subsubsection{Synthesis of Compounds 18 and 19}

(S)-(E)-Methyl 3-methyl-2-(4-styrylphenylsulfonamido)butanoate (39). Bromobenzene (12.2 mL, $116 \mathrm{mmol}), \mathrm{Pd}(\mathrm{OAc})_{2}(387 \mathrm{mg}, 1.74 \mathrm{mmol})$, TEA (17 mL), and $(\mathrm{o}-\mathrm{Tol})_{3} \mathrm{P}(1.06 \mathrm{~g}, 3.5 \mathrm{mmol})$ were added to a solution of $\mathrm{p}$-styrene sulfonic acid sodium salt $(20 \mathrm{~g}, 97 \mathrm{mmol})$ in DMF $(200 \mathrm{~mL}) / \mathrm{H}_{2} \mathrm{O}(4 \mathrm{~mL})$ mixture. The mixture was stirred at $100{ }^{\circ} \mathrm{C}$ for $2 \mathrm{~h}$. After cooling to RT, a gray solid $(21.9 \mathrm{~g}, 80 \%)$ separated out and was recovered by filtration, dried, and used in the next step without further purification. The solid was dissolved in $(87 \mathrm{~mL})$ /anhydrous DMF $(4.5 \mathrm{~mL})$ mixture and refluxed at $90{ }^{\circ} \mathrm{C}$ for $3 \mathrm{~h}$. The solvent was removed in vacuo and the residue was dissolved in EtOAc $(150 \mathrm{~mL})$ and washed successively with $2.0 \mathrm{~N} \mathrm{HCl}$, saturated $\mathrm{NaHCO}_{3}$, brine, and dried $\left(\mathrm{MgSO}_{4}\right)$. The EtOAc layer was recovered and concentrated under vacuum to give a gray solid (20.19 g, 93.3\%), which was used without further purification. The solid $(5 \mathrm{~g}, 17.95 \mathrm{mmol})$ was mixed with L-Val-OMe hydrochloride $(3.6 \mathrm{~g}, 21.47 \mathrm{mmol})$ and DIPEA $(4 \mathrm{~mL})$ in pyridine $(25 \mathrm{~mL})$ and the mixture was stirred for 4 days at RT, poured into $2.0 \mathrm{~N} \mathrm{HCl}$ and extracted with EtOAc. The extract was washed twice with aqueous $1 \mathrm{~N} \mathrm{HCl}$, saturated aqueous $\mathrm{NaHCO}_{3}$, brine, and dried $\left(\mathrm{MgSO}_{4}\right)$. The solvent was concentrated in vacuo and the residue was purified by column chromatography (acetone/hexane, 1:1) to give a white solid in $45 \%$ yield. m.p. $173-175^{\circ} \mathrm{C} .{ }^{1} \mathrm{H}$ NMR (DMSO- $\left.d_{6}\right) \delta 8.26(\mathrm{~d}, \mathrm{~J}=9.3), 7.639-7.800(\mathrm{~m}$, $6 \mathrm{H}), 7.295-7.472(\mathrm{~m}, 5 \mathrm{H}), 3.559(\mathrm{dd}, \mathrm{J}=7.2,9.0,1 \mathrm{H}), 3.359(\mathrm{~s}, 3 \mathrm{H}), 1.870-1.938(\mathrm{~m}$, $1 \mathrm{H}), 0.820(\mathrm{dd}, \mathrm{J}=6.9,9.0,6 \mathrm{H}) . \mathrm{MS}(\mathrm{ESI}) 372.0[\mathrm{M}-\mathrm{H}]^{-}, 396.1[\mathrm{M}+\mathrm{Na}]^{+} . \mathrm{IR}\left(\mathrm{cm}^{-1}\right)$ 1735 (ester), $3278(\mathrm{NH})$. 
(S)-(E)-3-Methyl-2-(4-styrylphenylsulfonamido)butanoic acid (40). $\mathrm{NaOH}$ $(4.0 \mathrm{~N}, 40 \mathrm{~mL})$ was added to a solution of 39 (6.85 g, $18.4 \mathrm{mmol})$ in $\mathrm{MeOH}(40 \mathrm{~mL})$ and acetone $(40 \mathrm{~mL})$ mixture and stirred for $16 \mathrm{~h}$ at $48{ }^{\circ} \mathrm{C}$ followed by adjustment of the $\mathrm{pH}$ to 2 with $2.0 \mathrm{~N} \mathrm{HCl}$ and extraction of the solid that separated out with EtOAc. The extract was washed with brine, dried $\left(\mathrm{MgSO}_{4}\right)$, filtered, and concentrated. The residue was purified by recrystallization from acetone/hexane to give a yellow solid 80\% yield. m.p. $193-195{ }^{\circ} \mathrm{C} .{ }^{1} \mathrm{H}$ NMR (DMSO- $\left.d_{6}\right) \delta 12.58(\mathrm{~s}, 1 \mathrm{H}), 8.01(\mathrm{~d}, \mathrm{~J}=9.7)$, $7.75(\mathrm{~s}, 4 \mathrm{H}), 7.65(\mathrm{~d}, \mathrm{~J}=7.2,2 \mathrm{H}), 7.29-7.46(\mathrm{~m}, 5 \mathrm{H}), 3.54(\mathrm{dd}, \mathrm{J}=6.0,9.0,1 \mathrm{H})$, 1.90-1.97 (m, 1H), $0.81(\mathrm{dd}, \mathrm{J}=6.9,9.6,6 \mathrm{H}) . \mathrm{MS}(\mathrm{ESI}) 358.0[\mathrm{M}-\mathrm{H}]^{-} . \mathrm{IR}\left(\mathrm{cm}^{-1}\right) 1747$ $(\mathrm{C}=\mathrm{O}), 3313(\mathrm{w}, \mathrm{COOH})$.

(S)-N-((S)-1-Hydroxy-4-methylpentan-2-yl)-3-methyl-2-(4-styrylphenylsulfonamido)-butanamide (41). L-Leucinol $(2.51 \mathrm{~mL}, 19.2 \mathrm{mmol})$ and TEA (4.53 mL, $32.5 \mathrm{mmol})$ were added to a solution of $40(5.3 \mathrm{~g}, 14.76 \mathrm{mmol})$ in anhydrous DMF $(150 \mathrm{~mL})$ at $0{ }^{\circ} \mathrm{C}$ followed by the addition of Mukayaima's reagent $(4.53 \mathrm{~g}, 17.7$ mmol). After stirring for 4 days at RT, the solution was poured into $\mathrm{H}_{2} \mathrm{O}(1.5 \mathrm{~L})$ to give the crude product, which was purified by recrystallization from ethyl acetate to obtain a white solid in $47 \%$ yield. m.p. $196-197^{\circ} \mathrm{C} .{ }^{1} \mathrm{H}$ NMR (DMSO- $d_{6}$ ) $\delta$ 7.62-7.79 $(\mathrm{m}, 7 \mathrm{H}), 7.54(\mathrm{~d}, \mathrm{~J}=8.7,1 \mathrm{H}), 7.28-7.43(\mathrm{~m}, 5 \mathrm{H}), 4.55(\mathrm{~s}, 1 \mathrm{H}), 3.48-3.56(\mathrm{~m}, 1 \mathrm{H})$, 3.04-3.19 (m, 2H), 1.80-1.86 (m, 1H), 1.10-1.18 (m, 2H), 0.99-1.04 (m, 1H), 0.63-0.86 (m, 12H). MS (ESI) 457.0 [M-H], $481.3[\mathrm{M}+\mathrm{Na}]^{+} . \mathrm{IR}\left(\mathrm{cm}^{-1}\right) 1638(\mathrm{C}=\mathrm{O})$, 3282 (sulfamide), 3205 (amide), 3503 (br, OH).

(S)-3-Methyl- $N$-((S)-4-methyl-1-oxopentan-2-yl)-2-(4-styrylphenylsulfonamido)butanamide (18). Oxidation of 41 (2.58 g, 5.63 mmol) with $\mathrm{PySO}_{3}$ complex (general procedure 4) followed by recrystallization of the crude product from ethyl acetate/hexane gave 18 as a white solid in $85 \%$ yield. m.p. $174-175{ }^{\circ} \mathrm{C} .{ }^{1} \mathrm{H}$ NMR (DMSO-d 6 ) $\delta 9.51(\mathrm{~s}, 1 \mathrm{H}), 7.85(\mathrm{~d}, \mathrm{~J}=8.5,2 \mathrm{H}), 7.62(\mathrm{~d}, \mathrm{~J}=8.5,2 \mathrm{H}), 7.42(\mathrm{t}, \mathrm{J}=8.0$, $2 \mathrm{H}), 7.35(\mathrm{t}, \mathrm{J}=7.5,1 \mathrm{H}), 7.25(\mathrm{~d}, \mathrm{~J}=16.5,1 \mathrm{H}), 7.10(\mathrm{~d}, \mathrm{~J}=16.5,1 \mathrm{H}), 6.12(\mathrm{~d}, \mathrm{~J}=7.5,1 \mathrm{H})$, $5.34(\mathrm{~d}, \mathrm{~J}=8.5,1 \mathrm{H}), 4.41-4.45(\mathrm{~m}, 1 \mathrm{H}), 3.62(\mathrm{dd}, \mathrm{J}=5.0,8.0,1 \mathrm{H}), 2.10-2.17(\mathrm{~m}, 1 \mathrm{H})$, $1.54-1.58(\mathrm{~m}, 1 \mathrm{H}), 1.41-1.49(\mathrm{~m}, 1 \mathrm{H}), 1.26-1.32(\mathrm{~m}, 1 \mathrm{H}), 0.96(\mathrm{~d}, \mathrm{~J}=6.5,3 \mathrm{H})$, 0.85-0.90 (m, 9H). MS (ESI) $374.0[\mathrm{M}-\mathrm{H}]^{-}, 398[\mathrm{M}+\mathrm{Na}]^{+}$. IR $\left(\mathrm{cm}^{-1}\right) 1637(\mathrm{C}=\mathrm{O})$, 1728 (CHO). Anal. Calcd. for: $\mathrm{C}_{25} \mathrm{H}_{32} \mathrm{~N}_{2} \mathrm{O}_{4} \mathrm{~S}, \mathrm{C}, 65.76 ; \mathrm{H}, 7.06 ; \mathrm{N}, 6.14 ; \mathrm{S}, 7.02$. Found: C, 65.51; H, 7.10; N, 6.13; S, 7.24.

\section{(2S)- $N$-((2S)-1-Cyano-1-hydroxy-4-methylpentan-2-yl)-3-methyl-2-(4-styr-} ylphenyl-sulfonamido)butanamide (42). $\mathrm{NaHSO}_{3}(3.2 \%, 14 \mathrm{~mL})$ was added to a solution of $18(2 \mathrm{~g}, 4.38 \mathrm{mmol})$ in $\mathrm{MeOH}(30 \mathrm{~mL})$ and stirred at RT for $40 \mathrm{~h}$ followed by the addition of $3.2 \% \mathrm{KCN}$ solution $(10 \mathrm{~mL})$ and EtOAc $(50 \mathrm{~mL})$. After stirring for another $5 \mathrm{~h}$, the mixture was extracted with EtOAc $(3 \times 50 \mathrm{~mL})$. The extract was concentrated and the residue was purified by recrystallization from acetone/hexane to give 19 as a white solid in $90 \%$ yield. m.p. $125-128{ }^{\circ} \mathrm{C} .{ }^{1} \mathrm{H} \mathrm{NMR}\left(\mathrm{CDCl}_{3}\right) \delta$ 7.09-7.88 $(\mathrm{m}, 11 \mathrm{H}), 6.53-6.69(\mathrm{~m}, 1 \mathrm{H}), 5.33-5.40(\mathrm{~m}, 1 \mathrm{H}), 4.51-4.59(\mathrm{~m}, 1 \mathrm{H}), 4.10-4.27(\mathrm{~m}$, $1 \mathrm{H}), 3.50-3.61(\mathrm{~m}, 1 \mathrm{H}), 2.15-2.25(\mathrm{~m}, 1 \mathrm{H}), 1.43-1.62(\mathrm{~m}, 3 \mathrm{H}), 0.81-0.98(\mathrm{~m}, 12 \mathrm{H})$. 
MS (ESI) 374.0 [M-H]-, $398[\mathrm{M}+\mathrm{Na}]^{+}$. IR ( $\left.\mathrm{cm}^{-1}\right) 1736$ (ester), 3282 (amide).

(3S)-Methyl-2-hydroxy-5-methyl-3-((S)-3-methyl-2-(4-styrylphenylsulfonamido)-butanamido) hexanoate (43). Compound 42 (932 mg, $19.4 \mathrm{mmol}$ ) was dissolved in $\mathrm{MeOH}(40 \mathrm{~mL})$ containing conc. $\mathrm{HCl}(11 \mathrm{~mL})$ and the mixture was stirred for $24 \mathrm{~h}$ at $54{ }^{\circ} \mathrm{C}$. The solvent was removed in vacuo and the residue was purified by column chromatography (acetone/hexane, 1:1) to give $\mathbf{4 3}$ as a white solid in $75.2 \%$ yield. m.p. $180-183{ }^{\circ} \mathrm{C} .{ }^{1} \mathrm{H}$ NMR $\left(\mathrm{DMSO}-d_{6}\right) \delta 7.28-7.73(\mathrm{~m}, 13 \mathrm{H})$, 5.35-5.58 (m, 1H), 3.83-3.97 (m, 2H), 3.58-3.68 (m, 1H), 1.79-1.83 (m, 1H), 1.01-1.27 (m, 3H), 0.55-0.91 (m, 12H). MS (ESI) $374.0[\mathrm{M}-\mathrm{H}]^{-}, 398[\mathrm{M}+\mathrm{Na}]^{+}$. IR $\left(\mathrm{cm}^{-1}\right) 1736$ (ester), 3282 (amide).

(3S)-2-Hydroxy-5-methyl-3-((S)-3-methyl-2-(4-styrylphenylsulfonamido) butanamido)-hexanamide (44). A solution of $43(750 \mathrm{mg}, 1.4 \mathrm{mmol})$ in $7.0 \mathrm{~N}$ methanolic ammonia $(30 \mathrm{~mL})$ was stirred at RT for $96 \mathrm{~h}$ and the mixture was concentrated to give a residue, which was purified by column chromatography (acetone/hexane, 2:1) to obtain 44 as a white solid in $64 \%$ yield. m.p. $234-242{ }^{\circ} \mathrm{C} .{ }^{1} \mathrm{H}$ NMR (DMSO-d $\left.)_{6}\right) \delta 7.04-7.77(\mathrm{~m}, 15 \mathrm{H}), 5.49-5.54(\mathrm{~m}, 1 \mathrm{H}), 3.96-4.03(\mathrm{~m}, 1 \mathrm{H})$, 3.58-3.71 (m, 2H), 1.84-1.93 (m, 1H), 1.24-1.34 (m, 1H), 1.03-1.15 (m, 2H), 0.53-0.87 (m, 12H). MS (ESI) 500.0 [M-H]. IR $\left(\mathrm{cm}^{-1}\right)$ 1660, $1643(\mathrm{C}=\mathrm{O}), 3326$ $(\mathrm{OH})$.

(S)-5-Methyl-3-((S)-3-methyl-2-(4-styrylphenylsulfonamido)butanamido)2-oxohexanamide (19). Oxidation of 44 (400 $\mathrm{mg}, 0.798 \mathrm{mmol}$ ) with pyridine-sulfur trioxide complex (general procedure 4 ) followed by flash chromatographic purification (acetone/hexane, 1:1) of the crude product gave $\mathbf{1 9}$ as a white solid in 52.7\% yield. m.p. $209-211^{\circ} \mathrm{C} .{ }^{1} \mathrm{H}$ NMR (DMSO-d $\left.{ }_{6}\right) \delta 8.12(\mathrm{~d}, \mathrm{~J}=6.9,1 \mathrm{H}), 7.97$ (s, 1H), 7.63-7,77 (m, 8H), 7.29-7.45 (m, 5H), 4.79 (t, J=7.2, 1H), 3.62 (dd, J=6.6, 9.3, 1H), 1.81-1.88 (m, 1H), 1.14-1.33 (m, 3H), 0.63-0.89 (m, 12H). MS (ESI) 498.0[M-H] $]^{-}, 554.3[\mathrm{M}+\mathrm{MeOH}+\mathrm{Na}]^{+} . \mathrm{IR}\left(\mathrm{cm}^{-1}\right) 1637(\mathrm{C}=\mathrm{O}), 1693(\mathrm{C}=\mathrm{O}), 1740$ $(\mathrm{C}=\mathrm{O}) 3124,3276,3359,3463$ (amide). Anal. Calcd. for: $\mathrm{C}_{26} \mathrm{H}_{33} \mathrm{~N}_{3} \mathrm{O}_{5} \mathrm{~S} \bullet 0.2 \mathrm{H}_{2} \mathrm{O}, \mathrm{C}$, 62.06; H, 6.69; N, 8.35; S, 6.37. Found: C, 62.01; H, 6.59; N, 8.33; S, 6.27.

\subsection{Determination of the Antiproliferative Activity of the Calpain Inhibitors}

\subsubsection{Cell Cultures}

Cell lines were cultured in a Dulbecco's modified Eagle's Medium (DMEM, Cellgro Mediatech, Inc.), supplemented with $5 \%(\mathrm{v} / \mathrm{v})$ fetal bovine serum (FBS, Atlanta Biologics, Inc.), 1\% (v/v) antibiotic/antimycotic solution (Sigma), and 0.05\% bovine insulin (25mM, pH 8.2, Sigma) for human A375 melanoma cells and mouse 
B16F1 melanoma cells. Cell cultures were maintained at $37{ }^{\circ} \mathrm{C}$ in a humidified atmosphere which contained $5 \% \mathrm{CO}_{2}$.

\subsubsection{Cell Death Assay and $\mathbf{G I}_{50}$ Value Determination in Melanoma Cells.}

During the initial screen, compounds dissolved in DMSO were added to the plates to give a $20 \mu \mathrm{M}$ solution followed by sulforhodamine B (SRB). To determine $\mathrm{GI}_{50}$ values, human melanoma cell line A375 and mouse melanoma cell line B16F1 were trypsinized and harvested by centrifugation for 3 minutes. Cells were then resuspended in the same media (5\% FBS, $1 \%$ antibiotic and $0.05 \%$ insulin in DMEM) and counted using a hemocytometer. Cells were seeded into U-bottom 96-well microtiter plate at 5000 cells/well. After $12 \mathrm{~h}$, media were changed and 8 dilutions of compounds were added. Cells were incubated with each compound for $48 \mathrm{~h}$. Positive controls were performed with taxol. Negative controls were performed with cells incubated with media only.

Cell death was quantitated by sulforhodamine B (SRB) assay according to the manufacturer's protocol (Sigma-Aldrich). ${ }^{172}$ Cells were fixed with $10 \%$ TCA, washed five times with tap water, and incubated with $0.4 \%$ sulforhodamine B in $1 \%$ acetic acid solution for $30 \mathrm{~min}$ at RT. $10 \mathrm{mM}$ solution of Tris Base (Fluka) was added to release the dye from the cells for $1 \mathrm{~h}$ and the absorbance was measured at $490 \mathrm{~nm}$ in EL800 Absorbance Microplate reader (Biotek). 


\section{LIST OF REFERENCES}

(1) Zeng, Y.; Li, Q.; Hanzlik, R. P.; Aube, J. Synthesis of a small library of diketopiperazines as potential inhibitors of calpain. Bioorg Med Chem Lett 2005, 15, 3034-3038.

(2) Sorimachi, H.; Ishiura, S.; Suzuki, K. Structure and physiological function of calpains. Biochem J 1997, 328, 721-732.

(3) Sanders, M. L.; Donkor, I. O. A novel series of urea-based peptidomimetic calpain inhibitors. Bioorg Med Chem Lett 2006, 16, 1965-1968.

(4) Donkor, I. O.; Korukonda, R.; Huang, T. L.; LeCour, L., Jr. Peptidyl aldehyde inhibitors of calpain incorporating P2-proline mimetics. Bioorg Med Chem Lett 2003, 13, 783-784.

(5) Lescop, C.; Herzner, H.; Siendt, H.; Bolliger, R.; Hennebohle, M. et al. Novel cell-penetrating alpha-keto-amide calpain inhibitors as potential treatment for muscular dystrophy. Bioorg Med Chem Lett 2005, 15, 5176-5181.

(6) Mehdi, S. Cell-penetrating inhibitors of calpain. Trends Biochem Sci 1991, 16, 150-153.

(7) Lee, K. S.; Seo, S. H.; Lee, Y. H.; Kim, H. D.; Son, M. H. et al. Synthesis and biological evaluation of chromone carboxamides as calpain inhibitors. Bioorg Med Chem Lett 2005, 15, 2857-2860.

(8) Mehdi, S.; Angelastro, M. R.; Wiseman, J. S.; Bey, P. Inhibition of the proteolysis of rat erythrocyte membrane proteins by a synthetic inhibitor of calpain. Biochem Biophys Res Commun 1988, 157, 1117-1123.

(9) Shirasaki, Y.; Miyashita, H.; Yamaguchi, M. Exploration of orally available calpain inhibitors. Part 3: Dipeptidyl alpha-ketoamide derivatives containing pyridine moiety. Bioorg Med Chem 2006, 14, 5691-5698.

(10) Fukiage, C.; Azuma, M.; Nakamura, Y.; Tamada, Y.; Nakamura, M. et al. SJA6017, a newly synthesized peptide aldehyde inhibitor of calpain: amelioration of cataract in cultured rat lenses. Biochim Biophys Acta 1997, 1361, 304-312.

(11) Inoue, J.; Nakamura, M.; Cui, Y. S.; Sakai, Y.; Sakai, O. et al. Structure-activity relationship study and drug profile of N-(4-fluorophenylsulfonyl)-L-valyl-L-leucinal (SJA6017) as a potent calpain inhibitor. J Med Chem 2003, 46, 868-871.

(12) Kupina, N. C.; Nath, R.; Bernath, E. E.; Inoue, J.; Mitsuyoshi, A. et al. The 
novel calpain inhibitor SJA6017 improves functional outcome after delayed administration in a mouse model of diffuse brain injury. $J$ Neurotrauma 2001, $18,1229-1240$.

(13) Donkor, I. O. A survey of calpain inhibitors. Curr Med Chem 2000, 7, 1171-1188.

(14) Li, Z.; Patil, G. S.; Golubski, Z. E.; Hori, H.; Tehrani, K. et al. Peptide alpha-keto ester, alpha-keto amide, and alpha-keto acid inhibitors of calpains and other cysteine proteases. J Med Chem 1993, 36, 3472-3480.

(15) Bartus, R. T.; Hayward, N. J.; Elliott, P. J.; Sawyer, S. D.; Baker, K. L. et al. Calpain inhibitor AK295 protects neurons from focal brain ischemia. Effects of postocclusion intra-arterial administration. Stroke 1994, 25, 2265-2270.

(16) Nomenclature committee of the International Union of Biochemistry (NC-IUB). Enzyme nomenclature. Recommendations 1978. Supplement 2: Corrections and additions. Eur J Biochem 1981, 116, 423-435.

(17) Goll, D. E.; Thompson, V. F.; Li, H.; Wei, W.; Cong, J. The calpain system. Physiol Rev 2003, 83, 731-801.

(18) Croall, D. E.; DeMartino, G. N. Calcium-activated neutral protease (calpain) system: structure, function, and regulation. Physiol Rev 1991, 71, 813-847.

(19) Guroff, G. A neutral, calcium-activated proteinase from the soluble fraction of rat brain. J Biol Chem 1964, 239, 149-155.

(20) Davis, T. L.; Walker, J. R.; Finerty, P. J., Jr.; Mackenzie, F.; Newman, E. M. et al. The crystal structures of human calpains 1 and 9 imply diverse mechanisms of action and auto-inhibition. $J$ Mol Biol 2007, 366, 216-229.

(21) Suzuki, K.; Hata, S.; Kawabata, Y.; Sorimachi, H. Structure, activation, and biology of calpain. Diabetes 2004, 53 Suppl 1, S12-18.

(22) Strobl, S.; Fernandez-Catalan, C.; Braun, M.; Huber, R.; Masumoto, H. et al. The crystal structure of calcium-free human m-calpain suggests an electrostatic switch mechanism for activation by calcium. Proc Natl Acad Sci U S A 2000, 97, 588-592.

(23) Hosfield, C. M.; Elce, J. S.; Davies, P. L.; Jia, Z. Crystal structure of calpain reveals the structural basis for $\mathrm{Ca}(2+)$-dependent protease activity and a novel mode of enzyme activation. Embo $J$ 1999, 18, 6880-6889.

(24) Saez, M. E.; Ramirez-Lorca, R.; Moron, F. J.; Ruiz, A. The therapeutic potential of the calpain family: new aspects. Drug Discov Today 2006, 11, 917-923. 
(25) Carragher, N. O. Calpain inhibition: a therapeutic strategy targeting multiple disease states. Curr Pharm Des 2006, 12, 615-638.

(26) Kishimoto, A.; Kajikawa, N.; Tabuchi, H.; Shiota, M.; Nishizuka, Y. Calcium-dependent neural proteases, widespread occurrence of a species of protease active at lower concentrations of calcium. J Biochem (Tokyo) 1981, 90, 889-892.

(27) Wang, K. K.; Yuen, P. W. Development and therapeutic potential of calpain inhibitors. Adv Pharmacol 1997, 37, 117-152.

(28) Rami, A. Ischemic neuronal death in the rat hippocampus: the calpain-calpastatin-caspase hypothesis. Neurobiol Dis 2003, 13, 75-88.

(29) Huang, Y.; Wang, K. K. The calpain family and human disease. Trends Mol Med 2001, 7, 355-362.

(30) Wikipedia. The Free Encyclopedia. EF hand. http://en.wikipedia.org/wiki/EF hand (accessed October 27, 2007)

(31) Vilei, E. M.; Calderara, S.; Anagli, J.; Berardi, S.; Hitomi, K. et al. Functional properties of recombinant calpain I and of mutants lacking domains III and IV of the catalytic subunit. J Biol Chem 1997, 272, 25802-25808.

(32) Khorchid, A.; Ikura, M. How calpain is activated by calcium. Nat Struct Biol 2002, 9, 239-241.

(33) Imajoh, S.; Kawasaki, H.; Suzuki, K. The amino-terminal hydrophobic region of the small subunit of calcium-activated neutral protease (CANP) is essential for its activation by phosphatidylinositol. J Biochem (Tokyo) 1986, 99, 1281-1284.

(34) Inomata, M.; Hayashi, M.; Nakamura, M.; Saito, Y.; Kawashima, S. Properties of erythrocyte membrane binding and autolytic activation of calcium-activated neutral protease. J Biol Chem 1989, 264, 18838-18843.

(35) Molinari, M.; Anagli, J.; Carafoli, E. Ca2+-activated neutral protease is active in the erythrocyte membrane in its nonautolyzed $80-\mathrm{kDa}$ form. $J$ Biol Chem 1994, 269, 27992-27995.

(36) Lin, G. D.; Chattopadhyay, D.; Maki, M.; Wang, K. K.; Carson, M. et al. Crystal structure of calcium bound domain VI of calpain at 1.9 A resolution and its role in enzyme assembly, regulation, and inhibitor binding. Nat Struct Biol 1997, 4, 539-547.

(37) Blanchard, H.; Grochulski, P.; Li, Y.; Arthur, J. S.; Davies, P. L. et al. Structure of a calpain $\mathrm{Ca}(2+)$-binding domain reveals a novel EF-hand and 
$\mathrm{Ca}(2+)$-induced conformational changes. Nat Struct Biol 1997, 4, 532-538.

(38) Sorimachi, H.; Toyama-Sorimachi, N.; Saido, T. C.; Kawasaki, H.; Sugita, H. et al. Muscle-specific calpain, p94, is degraded by autolysis immediately after translation, resulting in disappearance from muscle. J Biol Chem 1993, 268, 10593-10605.

(39) Nonneman, D.; Koohmaraie, M. Molecular cloning and mapping of the bovine and ovine skeletal muscle-specific calpains. Anim Genet 1999, 30, 456-458.

(40) Johnson, P. Calpains (intracellular calcium-activated cysteine proteinases): structure-activity relationships and involvement in normal and abnormal cellular metabolism. Int J Biochem 1990, 22, 811-822.

(41) Sorimachi, H.; Kinbara, K.; Kimura, S.; Takahashi, M.; Ishiura, S. et al. Muscle-specific calpain, p94, responsible for limb girdle muscular dystrophy type 2A, associates with connectin through IS2, a p94-specific sequence. $J$ Biol Chem 1995, 270, 31158-31162.

(42) Sorimachi, H.; Suzuki, K. Sequence comparison among muscle-specific calpain, p94, and calpain subunits. Biochim Biophys Acta 1992, 1160, 55-62.

(43) Sorimachi, H.; Ohmi, S.; Emori, Y.; Kawasaki, H.; Saido, T. C. et al. A novel member of the calcium-dependent cysteine protease family. Biol. Chem. Hoppe Seyler 1990, 371 Suppl, 171-176.

(44) Richard, I.; Broux, O.; Allamand, V.; Fougerousse, F.; Chiannilkulchai, N. et al. Mutations in the proteolytic enzyme calpain 3 cause limb-girdle muscular dystrophy type 2A. Cell 1995, 81, 27-40.

(45) Azuma, M.; Fukiage, C.; Higashine, M.; Nakajima, T.; Ma, H. et al. Identification and characterization of a retina-specific calpain (Rt88) from rat. Curr Eye Res 2000, 21, 710-720.

(46) Ma, H.; Shih, M.; Fukiage, C.; Azuma, M.; Duncan, M. K. et al. Influence of specific regions in Lp82 calpain on protein stability, activity, and localization within lens. Invest. Ophthalmol Vis Sci 2000, 41, 4232-4239.

(47) Ma, H.; Shih, M.; Hata, I.; Fukiage, C.; Azuma, M. et al. Lp85 calpain is an enzymatically active rodent-specific isozyme of lens Lp82. Curr Eye Res 2000, 20, 183-189.

(48) Lee, H. J.; Sorimachi, H.; Jeong, S. Y.; Ishiura, S.; Suzuki, K. Molecular cloning and characterization of a novel tissue-specific calpain predominantly expressed in the digestive tract. Biol Chem 1998, 379, 175-183.

(49) Sorimachi, H.; Saido, T. C.; Suzuki, K. New era of calpain research. 
Discovery of tissue-specific calpains. FEBS Lett 1994, 343, 1-5.

(50) Azuma, M.; Fukiage, C.; Higashine, M.; Nakajima, T.; Ma, H. et al. Identification and characterization of a retina-specific calpain (Rt88) from rat. Curr Eye Res 2000, 21, 710-720.

(51) Reverter, D.; Strobl, S.; Fernandez-Catalan, C.; Sorimachi, H.; Suzuki, K. et al. Structural basis for possible calcium-induced activation mechanisms of calpains. Biol Chem 2001, 382, 753-766.

(52) Yoshikawa, Y.; Mukai, H.; Hino, F.; Asada, K.; Kato, I. Isolation of two novel genes, down-regulated in gastric cancer. Jpn J Cancer Res 2000, 91, 459-463.

(53) Liu, K.; Li, L.; Cohen, S. N. Antisense RNA-mediated deficiency of the calpain protease, $\mathrm{nCL}-4$, in NIH3T3 cells is associated with neoplastic transformation and tumorigenesis. J Biol Chem 2000, 275, 31093-31098.

(54) Shiba, E.; Kambayashi, J. I.; Sakon, M.; Kawasaki, T.; Kobayashi, T. et al. $\mathrm{Ca} 2+-$ dependent neutral protease (calpain) activity in breast cancer tissue and estrogen receptor status. Breast Cancer 1996, 3, 13-17.

(55) Dear, T. N.; Moller, A.; Boehm, T. CAPN11: A calpain with high mRNA levels in testis and located on chromosome 6. Genomics 1999, 59, 243-247.

(56) Dear, T. N.; Boehm, T. Diverse mRNA expression patterns of the mouse calpain genes Capn5, Capn6 and Capn11 during development. Mech Dev 1999, 89, 201-209.

(57) Dear, T. N.; Meier, N. T.; Hunn, M.; Boehm, T. Gene structure, chromosomal localization, and expression pattern of Capn12, a new member of the calpain large subunit gene family. Genomics 2000, 68, 152-160.

(58) Dear, T. N.; Boehm, T. Identification and characterization of two novel calpain large subunit genes. Gene 2001, 274, 245-252.

(59) Dear, N.; Matena, K.; Vingron, M.; Boehm, T. A new subfamily of vertebrate calpains lacking a calmodulin-like domain: implications for calpain regulation and evolution. Genomics 1997, 45, 175-184.

(60) Horikawa, Y.; Oda, N.; Cox, N. J.; Li, X.; Orho-Melander, M. et al. Genetic variation in the gene encoding calpain-10 is associated with type 2 diabetes mellitus. Nat Genet 2000, 26, 163-175.

(61) Franz, T.; Vingron, M.; Boehm, T.; Dear, T. N. Capn7: a highly divergent vertebrate calpain with a novel C-terminal domain. Mamm Genome 1999, 10, 318-321. 
(62) Sun, W.; Ji, S. Q.; Ebert, P. J.; Bidwell, C. A.; Hancock, D. L. Cloning the partial cDNAs of mu-calpain and m-calpain from porcine skeletal muscle. Biochimie 1993, 75, 931-936.

(63) Baier, L. J.; Permana, P. A.; Yang, X.; Pratley, R. E.; Hanson, R. L. et al. A calpain-10 gene polymorphism is associated with reduced muscle mRNA levels and insulin resistance. J Clin Invest 2000, 106, R69-73.

(64) Evans, J. C.; Frayling, T. M.; Cassell, P. G.; Saker, P. J.; Hitman, G. A. et al. Studies of association between the gene for calpain-10 and type 2 diabetes mellitus in the United Kingdom. Am J Hum Genet 2001, 69, 544-552.

(65) Yang, X.; Pratley, R. E.; Baier, L. J.; Horikawa, Y.; Bell, G. I. et al. Reduced skeletal muscle calpain-10 transcript level is due to a cumulative decrease in major isoforms. Mol Genet Metab 2001, 73, 111-113.

(66) Horikawa, Y.; Oda, N.; Cox, N. J.; Li, X.; Orho-Melander, M. et al. Genetic variation in the gene encoding calpain-10 is associated with type 2 diabetes mellitus. Nat Genet 2000, 26, 163-175.

(67) Kretsinger, R. H. EF-hands embrace. Nat Struct Biol 1997, 4, 514-516.

(68) Yokoyama, Y.; Narahara, K.; Tsuji, K.; Ninomiya, S.; Seino, Y. Autosomal dominant congenital cataract and microphthalmia associated with a familial $\mathrm{t}(2 ; 16)$ translocation. Hum Genet 1992, 90, 177-178.

(69) Moore, S. A.; Shilling, C. J.; Westra, S.; Wall, C.; Wicklund, M. P. et al. Limb-girdle muscular dystrophy in the United States. J Neuropathol Exp Neurol 2006, 65, 995-1003.

(70) Walton, J. N.; Nattrass, F. J. On the classification, natural history and treatment of the myopathies. Brain 1954, 77, 169-231.

(71) Kramerova, I.; Beckmann, J. S.; Spencer, M. J. Molecular and cellular basis of calpainopathy (limb girdle muscular dystrophy type 2A). Biochim Biophys Acta 2007, 1772, 128-144.

(72) Bartoli, M.; Richard, I. Calpains in muscle wasting. Int J Biochem Cell Biol 2005, 37, 2115-2133.

(73) Harris, F.; Chatfield, L.; Singh, J.; Phoenix, D. A. Role of calpains in diabetes mellitus: a mini review. Mol Cell Biochem 2004, 261, 161-167.

(74) Adorini, L.; Gregori, S.; Harrison, L. C. Understanding autoimmune diabetes: insights from mouse models. Trends Mol Med 2002, 8, 31-38.

(75) Castano, L.; Eisenbarth, G. S. Type-I diabetes: a chronic autoimmune disease 
of human, mouse, and rat. Annu Rev Immunol 1990, 8, 647-679.

(76) Bach, J. F. Insulin-dependent diabetes mellitus as an autoimmune disease. Endocr Rev 1994, 15, 516-542.

(77) Harris, F.; Biswas, S.; Singh, J.; Dennison, S.; Phoenix, D. A. Calpains and their multiple roles in diabetes mellitus. Ann $N$ Y Acad Sci 2006, 1084, 452-480.

(78) Zatz, M.; Starling, A. Calpains and disease. $N$ Engl J Med 2005, 352, 2413-2423.

(79) Turner, M. D.; Cassell, P. G.; Hitman, G. A. Calpain-10: from genome search to function. Diabetes Metab Res Rev 2005, 21, 505-514.

(80) Biswas, S.; Harris, F.; Phoenix, D. A. Treatment of cataracts - vision for the future. Biologist (London) 2001, 48, 273-277.

(81) National Eye Institute. Cataract. http://www.nei.nih.gov/health/cataract/cataract facts.asp (accessed August 30, 2007).

(82) National Eye Institute. Vision Problems in the U.S. http://www.nei.nih.gov/eyedata/pdf/VPUS.pdf (accessed July 28, 2007).

(83) Biswas, S.; Harris, F.; Dennison, S.; Singh, J.; Phoenix, D. A. Calpains: targets of cataract prevention? Trends Mol Med 2004, 10, 78-84.

(84) Reed, N. A.; Castellini, M. A.; Ma, H.; Shearer, T. R.; Duncan, M. K. Protein expression patterns for ubiquitous and tissue specific calpains in the developing mouse lens. Exp Eye Res 2003, 76, 433-443.

(85) Shearer, T. R.; Ma, H.; Shih, M.; Fukiage, C.; Azuma, M. Calpains in the lens and cataractogenesis. Methods Mol Biol 2000, 144, 277-285.

(86) Ma, H.; Fukiage, C.; Kim, Y. H.; Duncan, M. K.; Reed, N. A. et al. Characterization and expression of calpain 10. A novel ubiquitous calpain with nuclear localization. J Biol Chem 2001, 276, 28525-28531.

(87) Wang, K. K.; Yuen, P. W. Calpain inhibition: an overview of its therapeutic potential. Trends Pharmacol Sci 1994, 15, 412-419.

(88) Sato, K.; Kawashima, S. Calpain function in the modulation of signal transduction molecules. Biol Chem 2001, 382, 743-751.

(89) Azuma, M.; David, L. L.; Shearer, T. R. Superior prevention of calcium ionophore cataract by E64d. Biochim Biophys Acta 1992, 1180, 215-220. 
(90) Biswas, S.; Harris, F.; Singh, J.; Phoenix, D. A. The in vitro retardation of porcine cataractogenesis by the calpain inhibitor, SJA6017. Mol Cell Biochem 2004, 261, 169-173.

(91) Braun, C.; Engel, M.; Seifert, M.; Theisinger, B.; Seitz, G. et al. Expression of calpain I messenger RNA in human renal cell carcinoma: correlation with lymph node metastasis and histological type. Int J Cancer 1999, 84, 6-9.

(92) Shiba, E.; Kim, S.; Fujitani, M.; Kambayashi, J. I.; Kawamura, I. et al. Possible involvement of calpain in the growth of estrogen receptor positive breast cancer cells. Anticancer Res 1996, 16, 773-777.

(93) Kimura, Y.; Koga, H.; Araki, N.; Mugita, N.; Fujita, N. et al. The involvement of calpain-dependent proteolysis of the tumor suppressor NF2 (merlin) in schwannomas and meningiomas. Nat Med 1998, 4, 915-922.

(94) Ohguchi, K.; Akao, Y.; Nozawa, Y. Involvement of calpain in melanogenesis of mouse B16 melanoma cells. Mol Cell Biochem 2005, 275, 103-107.

(95) Logothetou-Rella, H. The selective anticancer activity of the endogenous inhibitor of calcium-activated neutral proteinase. A histological, cytological and chemosensitivity study. Histol Histopathol 1994, 9, 485-493.

(96) Kamei, M.; Webb, G. C.; Young, I. G.; Campbell, H. D. SOLH, a human homologue of the Drosophila melanogaster small optic lobes gene is a member of the calpain and zinc-finger gene families and maps to human chromosome 16p13.3 near CATM (cataract with microphthalmia). Genomics 1998, 51, 197-206.

(97) Reichrath, J.; Welter, C.; Mitschele, T.; Classen, U.; Meineke, V. et al. Different expression patterns of calpain isozymes 1 and 2 (CAPN1 and 2) in squamous cell carcinomas (SCC) and basal cell carcinomas (BCC) of human skin. J Pathol 2003, 199, 509-516.

(98) Witkowski, J. M.; Zmuda-Trzebiatowska, E.; Swiercz, J. M.; Cichorek, M.; Ciepluch, H. et al. Modulation of the activity of calcium-activated neutral proteases (calpains) in chronic lymphocytic leukemia (B-CLL) cells. Blood 2002, 100, 1802-1809.

(99) Mamoune, A.; Luo, J. H.; Lauffenburger, D. A.; Wells, A. Calpain-2 as a target for limiting prostate cancer invasion. Cancer Res 2003, 63, 4632-4640.

(100) Lee, S. J.; Choi, Y. L.; Lee, E. J.; Kim, B. G.; Bae, D. S. et al. Increased expression of calpain 6 in uterine sarcomas and carcinosarcomas: an immunohistochemical analysis. Int J Gynecol Cancer 2007, 17, 248-253.

(101) National Institute on Aging. Alzheimer's Disease Fact Sheet. 
http://www.nia.nih.gov/Alzheimers/Publications/adfact.htm (accessed September 8, 2007).

(102) Yankner, B. A. Mechanisms of neuronal degeneration in Alzheimer's disease. Neuron 1996, 16, 921-932.

(103) Camins, A.; Verdaguer, E.; Folch, J.; Pallas, M. Involvement of calpain activation in neurodegenerative processes. CNS Drug Rev 2006, 12, 135-148.

(104) Lee, M. S.; Kwon, Y. T.; Li, M.; Peng, J.; Friedlander, R. M. et al. Neurotoxicity induces cleavage of p35 to p25 by calpain. Nature 2000, 405, 360-364.

(105) Kusakawa, G.; Saito, T.; Onuki, R.; Ishiguro, K.; Kishimoto, T. et al. Calpain-dependent proteolytic cleavage of the p35 cyclin-dependent kinase 5 activator to p25. J Biol Chem 2000, 275, 17166-17172.

(106) Nath, R.; Davis, M.; Probert, A. W.; Kupina, N. C.; Ren, X. et al. Processing of cdk5 activator p35 to its truncated form (p25) by calpain in acutely injured neuronal cells. Biochem Biophys Res Commun 2000, 274, 16-21.

(107) Iwamoto, N.; Thangnipon, W.; Crawford, C.; Emson, P. C. Localization of calpain immunoreactivity in senile plaques and in neurones undergoing neurofibrillary degeneration in Alzheimer's disease. Brain Res 1991, 561, 177-180.

(108) Saito, K.; Elce, J. S.; Hamos, J. E.; Nixon, R. A. Widespread activation of calcium-activated neutral proteinase (calpain) in the brain in Alzheimer disease: a potential molecular basis for neuronal degeneration. Proc Natl Acad Sci U S A 1993, 90, 2628-2632.

(109) Di Rosa, G.; Odrijin, T.; Nixon, R. A.; Arancio, O. Calpain inhibitors: a treatment for Alzheimer's disease. J Mol Neurosci 2002, 19, 135-141.

(110) Grynspan, F.; Griffin, W. R.; Cataldo, A.; Katayama, S.; Nixon, R. A. Active site-directed antibodies identify calpain II as an early-appearing and pervasive component of neurofibrillary pathology in Alzheimer's disease. Brain Res 1997, 763, 145-158.

(111) Nixon, R. A.; Saito, K. I.; Grynspan, F.; Griffin, W. R.; Katayama, S. et al. Calcium-activated neutral proteinase (calpain) system in aging and Alzheimer's disease. Ann N Y Acad Sci 1994, 747, 77-91.

(112) Lipton, P. Ischemic cell death in brain neurons. Physiol Rev 1999, 79, 1431-1568.

(113) Edelstein, C. L.; Ling, H.; Gengaro, P. E.; Nemenoff, R. A.; Bahr, B. A. et al. 
Effect of glycine on prelethal and postlethal increases in calpain activity in rat renal proximal tubules. Kidney Int 1997, 52, 1271-1278.

(114) Edelstein, C. L.; Ling, H.; Schrier, R. W. The nature of renal cell injury. Kidney Int 1997, 51, 1341-1351.

(115) Bronk, S. F.; Gores, G. J. pH-dependent nonlysosomal proteolysis contributes to lethal anoxic injury of rat hepatocytes. Am J Physiol 1993, 264, G744-751.

(116) Rami, A.; Krieglstein, J. Protective effects of calpain inhibitors against neuronal damage caused by cytotoxic hypoxia in vitro and ischemia in vivo. Brain Res 1993, 609, 67-70.

(117) Arlinghaus, L.; Mehdi, S.; Lee, K. S. Improved posthypoxic recovery with a membrane-permeable calpain inhibitor. Eur J Pharmacol 1991, 209, 123-125.

(118) Hiramatsu, K.; Kassell, N. F.; Lee, K. S. Improved posthypoxic recovery of synaptic transmission in gerbil neocortical slices treated with a calpain inhibitor. Stroke 1993, 24, 1725-1728.

(119) Markgraf, C. G.; Velayo, N. L.; Johnson, M. P.; McCarty, D. R.; Medhi, S. et al. Six-hour window of opportunity for calpain inhibition in focal cerebral ischemia in rats. Stroke 1998, 29, 152-158.

(120) Hong, S. C.; Goto, Y.; Lanzino, G.; Soleau, S.; Kassell, N. F. et al. Neuroprotection with a calpain inhibitor in a model of focal cerebral ischemia. Stroke 1994, 25, 663-669.

(121) Lee, K. S.; Frank, S.; Vanderklish, P.; Arai, A.; Lynch, G. Inhibition of proteolysis protects hippocampal neurons from ischemia. Proc Natl Acad Sci U S A 1991, 88, 7233-7237.

(122) Bartus, R. T.; Baker, K. L.; Heiseries, A. D. Postischemic administration of AK275, a calpain inhibitor, provides substantial protection against focal ischemic brain damage. J Cereb Blood Flow Metab 1994, 14, 537-544.

(123) Bartus, R. T.; Hayward, N. J.; Elliott, P. J.; Sawyer, S. D.; Baker, K. L. et al. Calpain inhibitor AK295 protects neurons from focal brain ischemia. Effects of postocclusion intra-arterial administration. Stroke 1994, 25, 2265-2270.

(124) Kohli, V.; Madden, J. F.; Bentley, R. C.; Clavien, P. A. Calpain mediates ischemic injury of the liver through modulation of apoptosis and necrosis. Gastroenterology 1999, 116, 168-178.

(125) Moldoveanu, T.; Campbell, R. L.; Cuerrier, D.; Davies, P. L. Crystal structures of calpain-E64 and -leupeptin inhibitor complexes reveal mobile loops gating the active site. J Mol Biol 2004, 343, 1313-1326. 
(126) Huang, Z.; McGowan, E. B.; Detwiler, T. C. Ester and amide derivatives of E64c as inhibitors of platelet calpains. J Med Chem 1992, 35, 2048-2054.

(127) Azuma, M.; David, L. L.; Shearer, T. R. Cysteine protease inhibitor E64 reduces the rate of formation of selenite cataract in the whole animal. Curr Eye Res 1991, 10, 657-666.

(128) Ray, S. K.; Matzelle, D. D.; Wilford, G. G.; Hogan, E. L.; Banik, N. L. Inhibition of calpain-mediated apoptosis by E-64 d-reduced immediate early gene (IEG) expression and reactive astrogliosis in the lesion and penumbra following spinal cord injury in rats. Brain Res 2001, 916, 115-126.

(129) Toda, G.; Matsushita, S.; Kuramoto, K.; Oda, S.; Ezaki, H. et al. Calcium-activated neutral protease inhibitor (E-64c) and reperfusion for experimental myocardial infarction. Jpn Heart J 1989, 30, 375-386.

(130) Angelastro, M. R.; Mehdi, S.; Burkhart, J. P.; Peet, N. P.; Bey, P. Alpha-diketone and alpha-keto ester derivatives of $\mathrm{N}$-protected amino acids and peptides as novel inhibitors of cysteine and serine proteinases. $J$ Med Chem 1990, 33, 11-13.

(131) Tao, M.; Bihovsky, R.; Wells, G. J.; Mallamo, J. P. Novel peptidyl phosphorus derivatives as inhibitors of human calpain I. J Med Chem 1998, 41, 3912-3916.

(132) Shirasaki, Y.; Nakamura, M.; Yamaguchi, M.; Miyashita, H.; Sakai, O. et al. Exploration of orally available calpain inhibitors 2: peptidyl hemiacetal derivatives. J Med Chem 2006, 49, 3926-3932.

(133) Wendt, A.; Thompson, V. F.; Goll, D. E. Interaction of calpastatin with calpain: a review. Biol Chem 2004, 385, 465-472.

(134) Murachi, T. Intracellular regulatory system involving calpain and calpastatin. Biochem Int 1989, 18, 263-294.

(135) Hanna, R. A.; Garcia-Diaz, B. E.; Davies, P. L. Calpastatin simultaneously binds four calpains with different kinetic constants. FEBS Lett 2007, 581, 2894-2898.

(136) Crawford, C. Protein and peptide inhibitors of calpains. Intracellular Calcium-Dependant Proteolysis; CRC: Boca Raton, FL, 1990; pp 75-89.

(137) Takano, E.; Ma, H.; Yang, H. Q.; Maki, M.; Hatanaka, M. Preference of calcium-dependent interactions between calmodulin-like domains of calpain and calpastatin subdomains. FEBS Lett 1995, 362, 93-97.

(138) Maki, M.; Ma, H.; Takano, E.; Adachi, Y.; Lee, W. J. et al. Calpastatins: 
biochemical and molecular biological studies. Biomed Biochim Acta 1991, 50, 509-516.

(139) Aoyagi, T.; Umezawa, H. Proteases and Biological Control; Cold Spring Harbor: Cold Spring Harbor, N.Y., 1975; pp 429-454.

(140) Ogura, K.; Maeda, M.; Nagai, M.; Tanaka, T.; Nomoto, K. et al. Purification and structure of a novel cysteine proteinase inhibitor, strepin P-1. Agric Biol Chem 1985, 49, 799-805.

(141) Saito, M.; Kawaguchi, N.; Hashimoto, M.; Kodama, T.; Higuchi, N. et al. Purification and structure of novel cysteine proteinase inhibitors, staccopins P1 and P2, from Staphylococcus tanabeenis. Agric Biol Chem 1987, 51, 861-868.

(142) Hiwasa, T.; Takeda, A.; Umezawa, K. Inhibition of thrombin and calpain by a ras inhibitor, damnacanthal. J Biochem Mol Biol Biophys 1999, 2, 311-316.

(143) Iizuka, H.; Iwasaki, Y.; Yamamoto, T.; Kadoya, S. Morphometric assessment of drug effects in experimental spinal cord injury. J Neurosurg 1986, 65, 92-98.

(144) Sasaki, T.; Kishi, M.; Saito, M.; Tanaka, T.; Higuchi, N. et al. Inhibitory effect of di- and tripeptidyl aldehydes on calpains and cathepsins. J Enzyme Inhib 1990, 3, 195-201.

(145) Ruetten, H.; Thiemermann, C. Effect of calpain inhibitor I, an inhibitor of the proteolysis of I kappa B, on the circulatory failure and multiple organ dysfunction caused by endotoxin in the rat. Br J Pharmacol 1997, 121, 695-704.

(146) Wilensky, R. L.; March, K. L.; Hathaway, D. R. Direct intraarterial wall injection of microparticles via a catheter: a potential drug delivery strategy following angioplasty. Am Heart J 1991, 122, 1136-1140.

(147) Crocker, S. J.; Smith, P. D.; Jackson-Lewis, V.; Lamba, W. R.; Hayley, S. P. et al. Inhibition of calpains prevents neuronal and behavioral deficits in an MPTP mouse model of Parkinson's disease. J Neurosci 2003, 23, 4081-4091.

(148) Harbeson, S. L.; Abelleira, S. M.; Akiyama, A.; Barrett, R., 3rd; Carroll, R. M. et al. Stereospecific synthesis of peptidyl alpha-keto amides as inhibitors of calpain. J Med Chem 1994, 37, 2918-2929.

(149) Lubisch, W.; Beckenbach, E.; Bopp, S.; Hofmann, H. P.; Kartal, A. et al. Benzoylalanine-derived ketoamides carrying vinylbenzyl amino residues: discovery of potent water-soluble calpain inhibitors with oral bioavailability. $J$ Med Chem 2003, 46, 2404-2412. 
(150) Bartus, R. T.; Baker, K. L.; Heiser, A. D.; Sawyer, S. D.; Dean, R. L. et al. Postischemic administration of AK275, a calpain inhibitor, provides substantial protection against focal ischemic brain damage. J Cereb Blood Flow Metab 1994, 14, 537-544.

(151) Caba, E.; Brown, Q. B.; Kawasaki, B.; Bahr, B. A. Peptidyl alpha-keto amide inhibitor of calpain blocks excitotoxic damage without affecting signal transduction events. J Neurosci Res 2002, 67, 787-794.

(152) Trumbeckaite, S.; Neuhof, C.; Zierz, S.; Gellerich, F. N. Calpain inhibitor (BSF 409425) diminishes ischemia/reperfusion-induced damage of rabbit heart mitochondria. Biochem Pharmacol 2003, 65, 911-916.

(153) Lubisch, W.; Moller, A. Discovery of phenyl alanine derived ketoamides carrying benzoyl residues as novel calpain inhibitors. Bioorg Med Chem Lett 2002, 12, 1335-1338.

(154) Lin, G. D.; Chattopadhyay, D.; Maki, M.; Wang, K. K.; Carson, M. et al. Crystal structure of calcium bound domain VI of calpain at 1.9 A resolution and its role in enzyme assembly, regulation, and inhibitor binding. Nat Struct Biol 1997, 4, 539-547.

(155) Wang, K. K.; Nath, R.; Posner, A.; Raser, K. J.; Buroker-Kilgore, M. et al. An alpha-mercaptoacrylic acid derivative is a selective nonpeptide cell-permeable calpain inhibitor and is neuroprotective. Proc Natl Acad Sci U S A 1996, 93, 6687-6692.

(156) Donkor, I. O. A survey of calpain inhibitors. Curr Med Chem 2000, 7, 1171-1188.

(157) Iqbal, M.; Messina, P. A.; B., F.; M., D.; S., C. et al. Subsite requirements for peptide aldehyde inhibitors of human calpain I. Bioorganic and Medicinal Chemistry Letters 1997, 7, 539-544.

(158) Chatterjee, S.; Gu, Z. Q.; Dunn, D.; Tao, M.; Josef, K. et al. D-amino acid containing, high-affinity inhibitors of recombinant human calpain I. $J$ Med Chem 1998, 41, 2663-2666.

(159) Tripathy, R.; Gu, Z. Q.; Dunn, D.; Senadhi, S. E.; Ator, M. A. et al. P2-proline-derived inhibitors of calpain I. Bioorg Med Chem Lett 1998, 8, 2647-2652.

(160) Chatterjee, S.; Iqbal, M.; Mallya, S.; Senadhi, S. E.; O'Kane, T. M. et al. Exploration of the importance of the P2-P3-NHCO-moiety in a potent di- or tripeptide inhibitor of calpain I: insights into the development of nonpeptidic inhibitors of calpain I. Bioorg Med Chem 1998, 6, 509-522. 
(161) Bihovsky, R.; Tao, M.; Mallamo, J. P.; Wells, G. J. 1,2-Benzothiazine 1,1-dioxide alpha-ketoamide analogues as potent calpain I inhibitors. Bioorg Med Chem Lett 2004, 14, 1035-1038.

(162) Wells, G. J.; Tao, M.; Josef, K. A.; Bihovsky, R. 1,2-Benzothiazine 1,1-dioxide $\mathrm{P}(2)-\mathrm{P}(3)$ peptide mimetic aldehyde calpain I inhibitors. J Med Chem 2001, 44, 3488-3503.

(163) Angelastro, M. R.; Marquart, A. L.; Mehdi, S.; Koehl, J. R.; Vaz, R. J. et al. The synthesis of ketomethylene pseudopeptide analogues of dipeptide aldehyde inhibitors of calpain. Bioorg Med Chem Lett 1999, 9, 139-140.

(164) Donkor, I. O.; Han, J.; Zheng, X. Design, synthesis, molecular modeling studies, and calpain inhibitory activity of novel alpha-ketoamides incorporating polar residues at the P1'-position. J Med Chem 2004, 47, 72-79.

(165) Donkor, I. O.; Zheng, X.; Miller, D. D. Synthesis and calpain inhibitory activity of alpha-ketoamides with 2,3-methanoleucine stereoisomers at the P2 position. Bioorg Med Chem Lett 2000, 10, 2497-2500.

(166) Donkor, I. O.; Zheng, X.; Han, J.; Lacy, C.; Miller, D. D. Significance of hydrogen bonding at the S(1)' subsite of calpain I. Bioorg Med Chem Lett 2001, 11, 1753-1755.

(167) Dothager, R. S.; Putt, K. S.; Allen, B. J.; Leslie, B. J.; Nesterenko, V. et al. Synthesis and identification of small molecules that potently induce apoptosis in melanoma cells through G1 cell cycle arrest. J Am Chem Soc 2005, 127, 8686-8696.

(168) Guan, N.; Korukonda, R.; Hurh, E.; Schmittgen, T. D.; Donkor, I. O. et al. Apoptosis induced by novel aldehyde calpain inhibitors in human tumor cell lines. Int J Oncol 2006, 29, 655-663.

(169) Lu, Q.; Mellgren, R. L. Calpain inhibitors and serine protease inhibitors can produce apoptosis in HL-60 cells. Arch Biochem Biophys 1996, 334, 175-181.

(170) Zhu, D. M.; Uckun, F. M. Calpain inhibitor II induces caspase-dependent apoptosis in human acute lymphoblastic leukemia and non-Hodgkin's lymphoma cells as well as some solid tumor cells. Clin Cancer Res 2000, 6, 2456-2463.

(171) Atencio, I. A.; Ramachandra, M.; Shabram, P.; Demers, G. W. Calpain inhibitor 1 activates p53-dependent apoptosis in tumor cell lines. Cell Growth Differ 2000, 11, 247-253.

(172) Li, W.; Wang, Z.; Gududuru, V.; Zbytek, B.; Slominski, A. T. et al. Structure-activity relationship studies of arylthiazolidine amides as selective 
cytotoxic agents for melanoma. Anticancer Res 2007, 27, 883-888. 


\section{VITA}

Jin Xu was born in June, 1979 in P. R. China. He received his bachelor degree in Pharmacy from China Pharmaceutical University. He entered the Pharmaceutical Sciences Graduate Program with a major in medicinal chemistry at the College of Pharmacy, University of Tennessee Health Science Center in August 2004. He was accepted into the medicinal chemistry lab of Dr. Isaac O. Donkor in the Department of Pharmaceutical Sciences. He expects to graduate in December 2007 with the degree of Master of Science in Pharmaceutical Sciences. 